\title{
Portland State University PDXScholar
}

1988

\section{The St. Josephs-Blatt, 1896-1919}

Steven Wayne Harmon

Portland State University

Follow this and additional works at: https://pdxscholar.library.pdx.edu/open_access_etds

Part of the German Language and Literature Commons, and the Journalism Studies Commons Let us know how access to this document benefits you.

\section{Recommended Citation}

Harmon, Steven Wayne, "The St. Josephs-Blatt, 1896-1919" (1988). Dissertations and Theses. Paper 3820.

https://doi.org/10.15760/etd.5704

This Thesis is brought to you for free and open access. It has been accepted for inclusion in Dissertations and Theses by an authorized administrator of PDXScholar. Please contact us if we can make this document more accessible: pdxscholar@pdx.edu. 
AN ABSTRACT OF THE THESIS OF Steven Wayne Harmon for the Master of Arts in German presented May 24, 1988.

Title: The St. Josephs-Blatt: $1896-1919$.

APPROVED BY MEMBERS OF THE THESIS COMMITTEE:

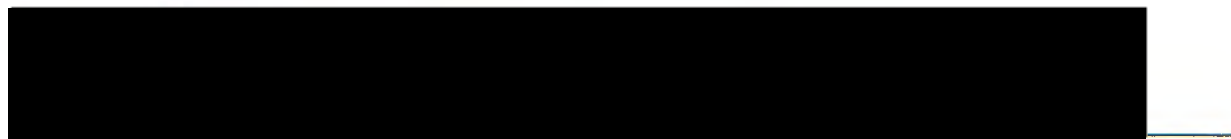

Louis J. Elteto, Chairman

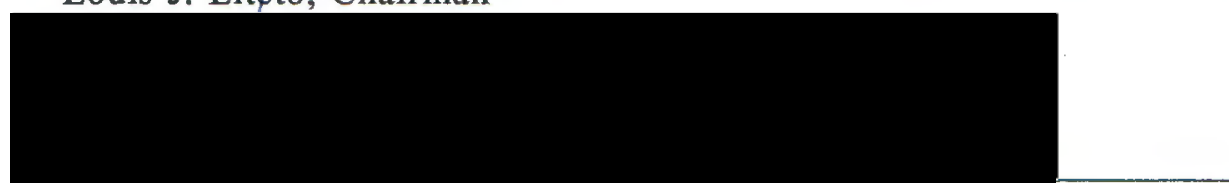

Linda Parshall

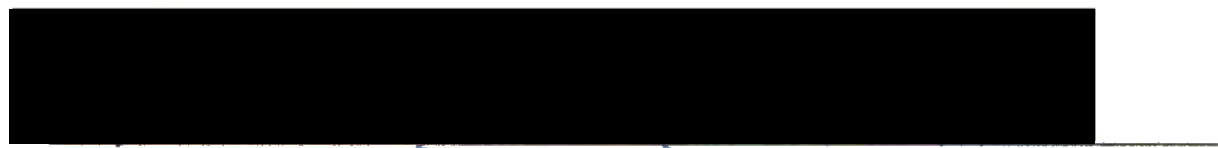

William Fischer

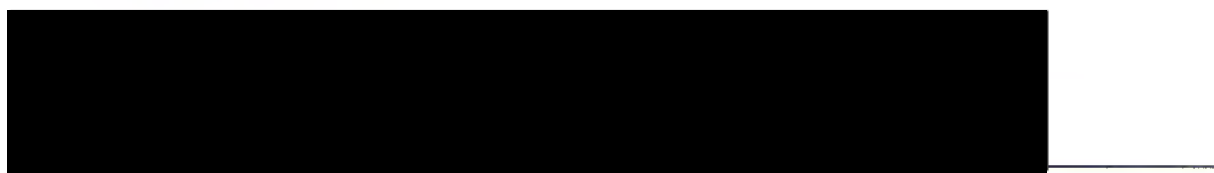

Franklin West

The St. Josephs-Blatt was a German-language newspaper published by the Benedictine monks of Mt. Angel Abbey from 1896 through 1952. The only fully extant collection of the St. Josephs-Blatt resides in the archives of Mt. Angel Abbey. The current archivist and Mt. Angel historian is Fr. Martin Pollard, who graciously allowed me to examine original copies of the newspaper and gave me the benefit of his personal historical expertise about both the paper and Br. Cölestin. For my research on the newspaper I did not use the original bound copies of the Blatt, which were too sensitive and brittle to handle safely, but a microfilm copy of the St. Josephs-Blatt, made by the University of Oregon Library in 1965. 
The aim of this thesis is to chronicle how the St. Josephs-Blatt dealt with the overriding issues facing German-American Catholics, namely, xenophobia, anti-Catholicism, and anti-Germanism particularly between the years 1896 and 1919. The articles, editorials, and special features published in the St. Josephs-Blatt are quoted and analyzed, both separately and in conjunction with secondary readings on the issues. I endeavor to analyze what was printed, why, and how the opinions of $\mathrm{Br}$. Cölestin, editor of the St. Josephs-Blatt from 1896 to 1929 , coincided with or differed from those of the prevailing American opinion and how those similarities or differences affected Br. Cölestin and his readers.

The thesis is divided into six chapters including introduction and conclusions. In the introduction the origins of the St. Josephs-Blatt are examined. I then review, in chapter two, the political and religious issues that the German-American Catholic faced prior to World War I. The following three chapters are divided by years: $1896-1914$, the years prior to the outbreak of World War I; 1914-1917, the war years prior to the entry of the United States into the war; 1917-1919, the years between America's entry into the war and the suppression of the St. Josephs-Blatt.

Having access to the St. Josephs-Blatt allowed me to experience 33 years of history through the writings of one man, Br. Cölestin. The thesis, then, is not only a chronicle of a newspaper, but an analysis of one man's ideas on religion, politics, war, language, and society. In the final analysis I have concluded that Br. Cölestin was a barometer of the feelings, ideals, fears and joys of the Northwest's German-American population. Despite his belief in his own ability to be impartial in his writings on Deutschtum in America and on the war, he could not separate himself from the personal viewpoint of his own origins. He was not an impartial observer, but a co-combatant in an ongoing battle, whose objectives were to keep Deutschtum alive in America, and during the war years, to make sure that the German side of the story was told. He 
considered his opinions to be objective and, for him, these goals were crucial, necessitated by a pro-British American English-language press and a predominant British heritage firmly imbedded in the American psyche. His opinions were important in keeping the German-American viewpoint vital, but it is impossible to say whether German-American editors like Br. Cölestin actually influenced America's neutrality policies and eventually war policies. As a voting block, German-Americans proved to be an effective force with which politicians had to deal. In the end their endeavors failed. Why, must be the subject of another thesis. 
The ST. JOSEPHS-BLATT:

$1896-1919$

by

STEVEN WAYNE HARMON

A thesis submitted in partial fulfillment of the requirements for the degree of

\section{MASTER OF ARTS}

in

GERMAN

Portland State University

1988 
TO THE OFFICE OF GRADUATE STUDIES:

The members of the Committee approve the thesis of Steven Wayne Harmon presented May 24, 1988.

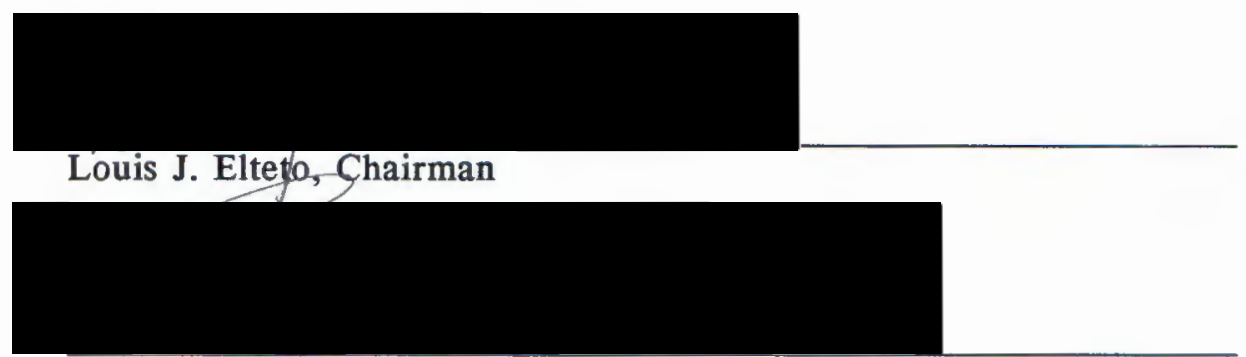

Linda Parshall

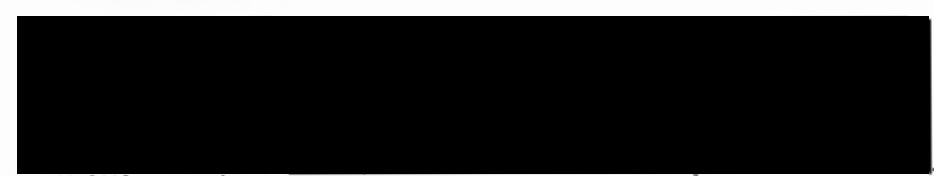

William Fischer

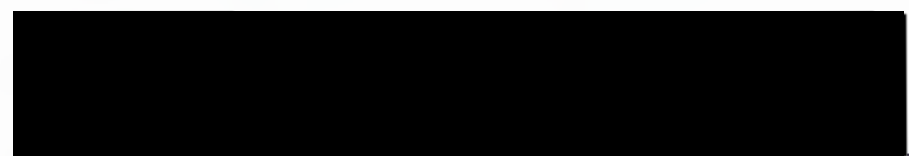

Franklin West

APPROVED:

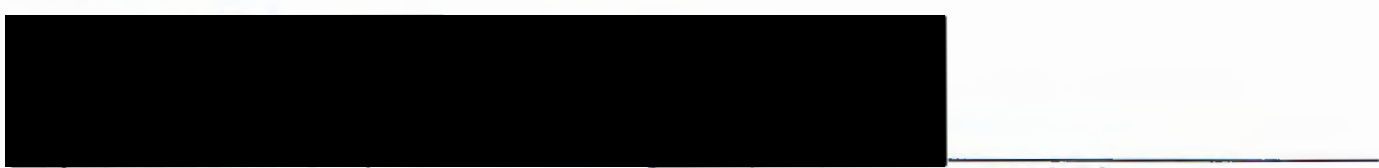

Linda Parshall, Chair, Department of Foreign Languages and Literatures

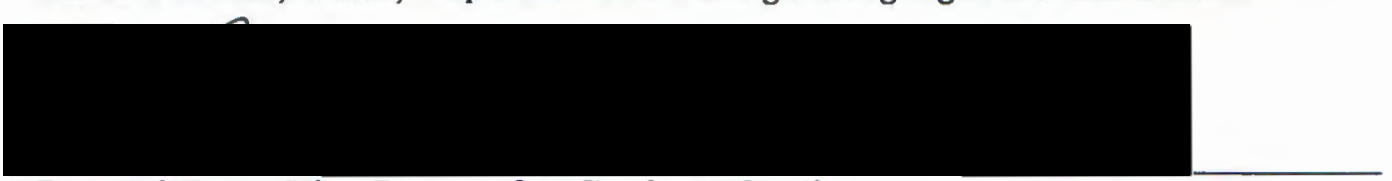

Bernard Ross, Vice Provost for Graduate Studies 


\section{ACKNOWLEDGMENTS}

Seldom has a graduate student been so indebted to so many for so much. I want to acknowledge the many people who have generously given me their support: Dr. Louis J. Elteto, my Magistervater, for his encouragement, and guidance; my committee members, Dr. Linda Parshall, Dr. William Fischer, and Dr. Frank West for their years of encouragement, enlightenment, and prodding; Dr. Patricia Wetzel, for her personal, and professional concern; Elizabeth Hengeveld, M.A., and Mari Noda, M.A., for their questions, suggestions, and for listening; Dr. Peter Parshall, for his interest and curiosity; Daphne M. Couch, M.A., for her constant belief, encouragement, and amazing erudition; Karin Herrmann, M.A., Tieneke Bierma, M.A., and Inger Olsen, M.A., for providing me with positive role models; Dr. Charles M. White, Dawn White, Anne Bender, Margaret Herrington, Nancy Goldman, Miles Turner, Jane Quigley, and Shirley Kremer for their personal and professional assistance, patience, and caring. I thank you all. 
TABLE OF CONTENTS

PAGE

ACKNOWLEDGEMENTS $\cdot$ •

\section{CHAPTER}

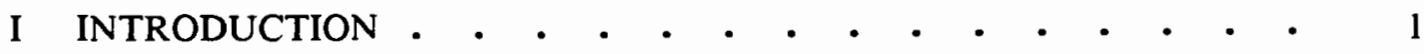

II THE ORIGINS OF THE ST. JOSEPHS-BLATT • • • • • • • 3

III THE POLITICAL ISSUES FACING THE ST. JOSEPHS-BLATT

BEFORE WORLD WAR I • • • • • • • • • • • • 6

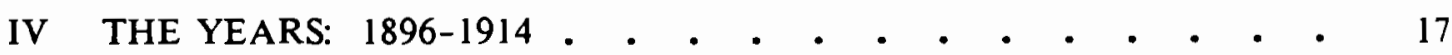

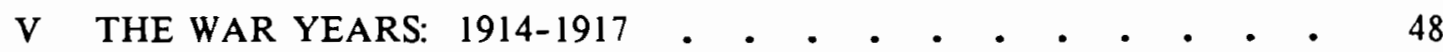

VI THE FINAL YEARS: 1917-1919 • . . . • . • . . . . 114

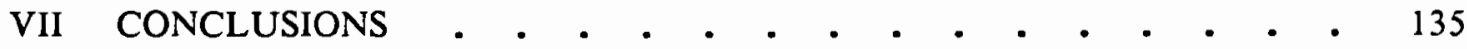

BIBLIOGRAPHY . . . . . . . . . . . . . . . . 137 


\section{CHAPTER I}

\section{INTRODUCTION}

The intent of this thesis was to examine the St. Josephs-Blatt from January 1896 through September 1919 and record any articles, editorials, headlines, special features, or advertisements that referred to 1) Germany, or German culture, customs, or language, either positively or negatively; 2) England, or English culture and heritage, either positively or negatively; and 3) the sentiments of others against Catholicism, Germany (including Austria-Hungary), or immigration. I analyzed these articles for purpose, mood, attitude, and viewpoint. I was looking for the newspaper's views on the Germanic heritage it shared with most of its subscribers; its views on the English heritage that it did not share with the majority of Americans; and its views on those agitating against "Deutschtum" in the United States. My intention was to determine what these views were, how and why they were formed, and how they affected the newspaper and its readers.

As to the sociological, religious, and political issues germane between 1896 and 1919, I used the secondary literature listed in the bibliography as my source of information. I specifically investigated xenophobia in the United States (KnowNothingism, anti-Catholicism), ethnic newspapers, and Catholicism in the Northwest. I contrasted what I learned about these subjects with what appeared in the St. JosephsBlatt.

What I found was a German-American Catholic newspaper, edited by a German-speaking Swiss monk, who as a staunch, unswerving supporter of 
"Deutschtum," and a vigilant protector of Catholic faith did not hesitate to openly, and at times defiantly, defend his heritage, language, and faith against any detractors.

The only fully extant collection of the St. Josephs-Blatt resides in the archives of Mt. Angel Abbey, in Mt. Angel, Oregon. Because the original newspapers are extremely sensitive and brittle, as well as so far from Portland, all research was done with the use of microfilmed copies of the newspaper, which had been made by the University of Oregon in 1965. A few of the films were of poor quality, at times completely illegible. This meant that a number of editions of the paper were not examined. I do not believe, however, that this problem adversely affected the research. 


\section{CHAPTER II}

\section{THE ORIGINS OF THE ST. JOSEPHS-BLATT.}

The St. Josephs-Blatt was founded in 1887 by Fr. Alois Sommer, the GermanAmerican pastor of St. Joseph's Catholic Church in southeast Portland, Oregon. His parish was a German speaking congregation, with the inherent German customs and traditions.

Little is known about Fr. Sommer except that as a pastor of an ethnic parish, he wanted to do more than just preach to his parishioners on Sundays, baptize their children and teach an occasional catechism course. He wanted to contribute to their day-to-day lives. ${ }^{1}$ To that end Fr. Sommer decided in 1887 to publish a monthly newspaper, written in German and dedicated to news that would interest his congregation. Accordingly, the St. Josephs-Blättchen was born. ${ }^{2}$

In its first year of publication Fr. Sommer was the sole editor, typesetter, proof reader, and printer of the Blättchen. His nephew and a member of the parish, Ernst Sommer, later worked as his aide and assistant. Sister Dominika, a Benedictine nun from St. Joseph's Grade School in Portland replaced Ernst after he left to begin his university studies.

The Blättchen began as a simple monthly publication, but as this small, part-time project grew in popularity and correspondingly in circulation, the paper's publishing schedule was increased to semimonthly. Fr. Sommer eventually found it necessary to

1 "Fünfzig Jahre St. Josephs-Blatt: Das goldene Jubiläum des St. JosephsBlattes," St. Josephs-Blatt [1938], special edition: 1 .

2 "Fünf zig" 1. 
change the layout from two columns to three. By 1888 the demand for the Blättchen had grown too great for Fr. Sommer and Sister Dominika to handle effectively. Fr. Sommer began to look for options to continue its publication, and was able to find assistance in the small village of Filmore, Oregon. Filmore, founded around 1849, was originally a community of German farmers. In 1882 this group had asked Archbishop Seghers, the Oregon prelate, for permission to establish a German church. ${ }^{3}$ Father Adelhelm Odermatt, a monk sent from the Swiss Abbey of Engelberg to find a suitable location for a Benedictine monastery in the United States, became convinced that Filmore would be the ideal place to build a priory and school. The Archbishop agreed and gave Fr. Odermatt permission to begin. A Benedictine Priory was then founded in 1882 , and it was to these Swiss monks that Fr. Sommer turned. After some debate among the community, Prior Odermatt informed Fr. Sommer that the Priory would take over the publishing of what Odermatt called Fr. Sommer's "Käfeblättchen." Despite a lack of funds, the Benedictines were confident that St. Joseph, their patron saint, would provide them with the needed support. ${ }^{5}$

Fr. Leo Hübscher, O.S.B., was chosen to be the first editor of Mt. Angel's new newspaper, but his tenure lasted only a short six months before he was transferred to a university in Washington. An ideal choice as his replacement was a 22 year-old printer from Switzerland who in 1888 petitioned to join the Order of St. Benedict at Mt. Angel, Oregon. This printer, Wilhelm Müller, who would later take the name Brother Cölestin,

3 Lawrence J. McCrank, Mt. Angel Abbey: A Centennial History of the Benedictine Community and its Library. 1882-1982 (Wilmington, Delaware: Scholarly Resources Inc., 1893) 24.

4 Martin Pollard, O.S.B., "Mount Angel Abbey: Chronicle of 100 Years," Mt. Angel Letter 33 (February 1982): 5.

5 "Fünf zig" 2. 
was born in 1866 , and had learned the printing trade in Switzerland as well as in Austria and Berlin before emigrating to America. ${ }^{6}$

In 1889, when Brother Cölestin took over the editorial duties of the paper, the first modifications he instituted were to change its name to the St. Josephs-Blatt, enlarge the format, increase the number of pages, and change the semimonthly publication schedule to weekly.

Br. Cölestin continued as the editor of the St. Josephs-Blatt up to the day of his death on June 12, 1929. The development of the newspaper was due to this monk, who guided it through the long, of ten controversial years of growth. He saw the Blatt grow from a small church-oriented monthly to an internationally read weekly concerned not only with the Church but also with local and international politics; a newspaper that was concerned about Catholics, German-Americans, Germany, and the world. The Blatt, under the guidance of $\mathrm{Br}$. Cölestin, became a voice in the defense of the German people, culture and language, especially as they affected the local and national character of the German-American communities in Oregon and the West Coast.

6 "Fünf zig" 2. 


\section{CHAPTER III}

\section{THE POLITICAL ISSUES FACING THE $S T$. JOSEPHS-BLATT BEFORE WORLD WAR I}

The first part of this study is a profile of the St. Josephs-Blatt and the positions Br. Corlestin took on the prevailing issues of the times, particulary his views on xenophobia and anti-Catholicism.

In the late 19th century German-Americans and Catholics, although in many instances separate groups, were both considered minorities in the United States. As outsiders, they felt the effects of the xenophobia that prevailed in the United States in the late 1800 's and the early 1900 's.

The reader should not be surprised to find that the German-American Catholics found themselves in a unique and precarious position in the history of the xenophobic movement in the United States. As an immigrant or the child of one, the GermanAmerican was suspect. As an immigrant Catholic he was under double suspicion. He could be accused of everything from vagrancy to divided loyalties. The charge of complicity in all types of devious plots and subplots could be levelled against him. The St. Josephs-Blatt was one line of defense for the German-American Catholic.

Only a few of the colonists arriving on the eastern shores of the New World were members of the English Catholic Church, and those who were found themselves restricted essentially to two colonies, Maryland and Pennsylvania. ${ }^{7}$ This small group was eventually augmented by other Catholic ethnic groups, such as the Irish, Germans and French. All

7 Philip Gleason, Catholicism in America, Interpretations of American History (New York: Harper \& Row, 1970) 12. 
were slowly absorbed by the English Catholic minority, which maintained its English cultural dominance. 8

Catholicism, therefore, cannot be considered a foreign export to the American colonies or the United States. Nor is anti-Catholicism a new phenomenon in America. It came to the New World with the Puritans of Massachusetts Bay and the Anglicans of Virginia. ${ }^{9}$ Both groups had in common the hatred of the Roman Church. The Reformation was still fresh in the minds of these colonists. Ray Allen Billington, in The Protestant Crusade, informs us: "The settlers who came to America, reared in this atmosphere of intolerance, carried with them to the new land the same hatred of Popery which characterized the England of that day."

Anti-Catholic prejudice affected all aspects of the lives of the few Catholics who ventured to the New World. They were taxed more highly; they were denied the companionship of priests; many colonies refused Catholics entrance altogether; many banished Catholics. ${ }^{10}$ The small, ethnicly disparate group of Catholics, whose customs, traditions and languages differed greatly, did survive, however, by assimilating into the predominately Anglo-Saxon culture of the colonies. ${ }^{11}$

In the mid nineteenth century, immigrants from all over the world began arriving in greater numbers including many more Catholics. By 1830 Catholics were still in the minority in the United States (approximately 700,000 out of $11,000,000$ inhabitants were Catholics.) ${ }^{12}$, but the number of immigrants rose from about 10,000 per year between

8 Gleason 12.

9 Ray Allen Billington, The Protestant Crusade, 1800-1860. A Study of the Origins of American Nativism (New York: Rinehart \& Co., Inc., 1952) 1.

10 Billington 1.

11 Billington 4.

12 Carleton Beals, Brass-Knuckle Crusade. The Great Know-Nothing Conspiracy: 1820-1860 (New York: Hastings House, 1960) 9. 
1790 and 1820 to almost 250,000 in 1879 , which meant a similar percentage increase in the Catholic population. ${ }^{13}$

Immigrants were streaming into the United States for many reasons. In their homelands political, social, and economic pressures were giving many people good reasons to leave. The revolutions of 1848 in Europe created numerous refugees looking for political freedom in the United States. Many Germans left Germany to escape the rise of German militarism and if they were Catholics, to escape Otto von Bismarck's Kulturkampf. ${ }^{14}$

After 1865 a new military-industrial society had a deleterious effect on traditional craftsmen and small shopkeepers in Germany. Many Germans witnessed an end to their traditional way of life. Coming to the New World, these immigrants brought their own ideas about society, politics, and religion, which did not always coincide with the traditional ways of doing things in America.

Certain characteristics of the immigrants arriving in the United States began to be sources of irritation and confrontation between them and "native" Americans. Poverty was common among those men and women coming to America from the Old World. Many were forced to leave their homelands with nothing except what money they could gather together after selling their meager possessions. Others were banished from their homelands with little or no chance to liquidate their assets. Still others had nothing to sell or to bring.

The lack of property and assets forced many people to rely on local charity programs and organizations in the cities and states in which they settled, most of which were inadequate. The average man-on-the-street saw only dirty, seemingly uneducated,

13 Max Farrand, "Immigration in the Light of History," New Republic IX (December 23, 1916) 209.

14 John Cogley, Catholic America (New York: The Dial Press, 1973) 150. 
poverty-stricken foreigners and was left with the impression that immigrants were nothing but an unproductive drain on the already strained social services available. Prejudices began to form early.

Many of the ideas and attitudes of the newly-arrived immigrants were by-products of the revolution in Europe. These ideas included such time-honored American traditions as freedom of religion and a free press; but along with these were new ideas: direct voting, abolition of property qualifications for voting, the right of referendum and recall, popular suffrage primaries, the emancipation of women, and non-sectarian education. Immigrants also brought an appreciation of culture and art which directly confronted the traditional American puritanical distrust of all the arts.

But of all the ideas the immigrants imported into this country, the most provocative were new religious creeds. New Protestant splinter groups were looked upon with distaste and distrust; Roman Catholicism "aroused hate and terror."15

A political reaction to the increase of Catholic immigrants coming to the United States was the rise of the "nativist movement." A nativist was someone who reacted with hostility to the personal and cultural characteristics of a foreigner and, most importantly, combined this hostility with a fervent desire to protect a distinctly American way of life. ${ }^{16}$ John Higham defines nativism as "intense opposition to an internal minority on the ground of its foreign (i.e., 'un-American') connections." Suddenly it was popular to be a native son and uncomfortable to be from a foreign country.

Thus, modern American nationalism was born. At first the nativists banded together in political groups, which gradually became known collectively as the Native American Parties. Coalescing into the American Party, they began to exert more and

15 Beals 8.

16 John Higham, Send These to Me. Immigrants in Urban America (Baltimore: The Johns Hopkins University Press, 1984) 24. 
more pressure on the American political scene. "Americanism" became a philosophy of the nativist. One American nativist group proclaimed "the grand work of the American party is the principle of nationality...we must do something to protect and vindicate it. If we do not it will be destroyed."17

Soon secret societies, dedicated to maintaining the purity of the race and "pride of

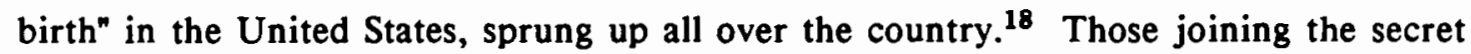
societies were looking for others with ideas and sentiments congenial to their own.

One of the first such organizations that gained national notoriety was the "Order of the Star Spangled Banner." Founded in 1854 in New York City, this at first insignificant group gained enough recognition and membership to influence not only local and state but also national politics. ${ }^{19}$ Suspected members of this organization, when questioned about its existence and secret rituals, answered with a uniform "I know nothing about it." This evasive answer was so typical that those using it quickly became known as "Know-Nothings", and the term became the popular designation for the movement and the political party. ${ }^{20}$

The Know-Nothings reflected the political ideas of a large segment of the American population who considered "free thinkers" and intellectuals threatening to the Republic. ${ }^{21}$ Immigrants with their new ideas, and cultures were scorned by the KnowNothings and, with the increase in the number of Catholics, the nativists began to focus on that vocal group of immigrants.

17 Sr. M. Evangeline Thomas, Nativism in the Old Northwest, 1850-1860 (Washington, 1936) 131.

18 Beals 9.

19 Peter J. Rahill, The Catholic in America. From Colonial Times to the Present Day (Chicago: Franciscan Herald Press, 1961) 104.

20 Rahill 20.

21 Beals 12-13. 
Most of the vitriol against the Catholics was aimed at the "whore of Babylon," the Church itself. The feeling in the country was that Catholics, under the orders of the Church, were intent on taking over America and then forcing America to subordinate itself to Rome.

Catholics were conceived as puppets of the pope. Influenced and controlled by the Church, they could not give allegiance to America but only to Rome. Anti-Catholic prejudice became so prevalent that it took on an almost hysterical mien. The security of Catholic churches was threatened by destruction by fire and vandalism. Priests and nuns were ridiculed, threatened, and maligned on the streets as well as in print. Convents were labelled brothels, and priests accused of every form of debauchery and perversion.

The hysterical anti-Catholic propaganda was so widespread and insidious, that it created a goldmine of "profit and power for propagandists and unscrupulous politicians." 22 Novels and "autobiographies" were published about and by "nuns" describing unheard of horrors committed in the name of the Catholic Church. Especially popular were stories about nuns who had escaped from convents, where they had been allegedly forced to submit to the bidding of perverted priests. Politicians began to win elections by espousing an anti-Catholic platform.

In the 1860's the anti-Catholic hysteria began to wane as the mood of the country gradually mellowed toward Catholics and immigrants in general. Nativism, however, did not disappear, nor did anti-Catholicism. By 1870 nativism was almost an institution unto itself. Perhaps less vocal, the nativists nonetheless continued to raise the anti-Catholic banner throughout the years following the Civil War and some say they have continued to do so to this very day. ${ }^{23}$

22 Beals 60.

23 See Andrew M. Greeley, An Ugly Little Secret: Anti-Catholicisim in North America (Kansas City: Sheed Andrews \& McNeel, 1977) regarding the continued nativist movement in contemporary America. 
By the 1870's the movement against Catholicism was directed more towards the clerics and the Church hierarchy than towards the Catholic laity. Because of their demands for more input into the education of Catholic children, equitable funding in the schools, and elimination of the "Protestant tinge" that Bible reading gave to the public schools, the Catholic clergy was considered the predominant enemy of the Protestant status quo in the United States. ${ }^{24}$

In the 1870's most state school systems were under the control of private "benevolent Protestant societies" supported by tax money. They were only nominally public and non-sectarian, but in reality religiously based and biased against Catholics and other religious minorities. ${ }^{25}$ The Church began to demand private schools for its children, as it was obvious to all Catholics that the publicly run schools were blatantaly anti-Catholic. Almost all the public schools used the King James Bible as a basic reader, and most schools compelled students to attend Protestant religious services. ${ }^{26}$ Other texts used in the public schools also belittled Roman Catholicism. The Church began to look for alternate means to educate its children; ways in which they would not be exposed to the anti-Catholic teachings with which Catholic children were continually bombarded. It was felt that the faith of Catholic children was in peril. The nonCatholic, however, saw this drive for separate schools as a resurgence of popery: a gradual, insidious papal plot to subsume American public education.

Simultaneously with the resurrection of resentment against the Church, rose another concern in the American native. According to John Higham, writing in Strangers in the Land: Patterns of American Nativism, 1860-1925, fervent American patriotism was

24 Higham 28.

25 Beals 28.

26 Beals 28. 
declining because of the growing influence and power of the immigrant. ${ }^{27}$ Yet the slow pace of assimilation of the immigrant into a "homogeneous people" began to cause the nativist worry. ${ }^{28}$

By the 1890's the nativist was championing American nationalism again. Now, however, the immigrant was viewed as good for America, if and when he assimilated into society. As soon as he became American or was "Americanized" he became an asset to the nation. Americanization became the focal point of the nativist.

Catholic immigrants faced not only protestant pressure to Americanize, but also pressure from within the Church itself. Many American Catholics had their own ideas about immigrants, who were different and had their own way of doing things. Native members of the Church, led by their religious leaders, began to require conformity and unity from the foreigners filling their churches. The immigrant was expected to assume American cultural characteristics, language, and customs. They were expected to assimilate and to do so as quickly as possible. Many prominent Catholic lay and religious leaders felt that assimilation was too important to leave to chance or to natural progression. They began a concerted effort to hasten immigrant Catholic absorption into mainstream American culture.

Notable Catholic leaders such as Orestes A. Brownson (1803-1876), and Isaac Hecker (Founder of the Paulist Order), would advocate fast and immediate assimilation of immigrant Catholics. Although active at different times (sometime between 1820 and 1920) they had common objectives. Orestes A. Brownson, active between 1820 and 1860 , wanted to "eliminate the distinction" between the native-born Catholic and the immigrant

27 John Higham, Strangers in the Land: Patterns of American Nativism, 18601925 (New Brunswick: Rutgers University Press, 1955) 74-75.

28 Higham, Strangers 63. 
Catholic completely and immediately. ${ }^{29} \mathrm{He}$ believed total cultural assimilation would

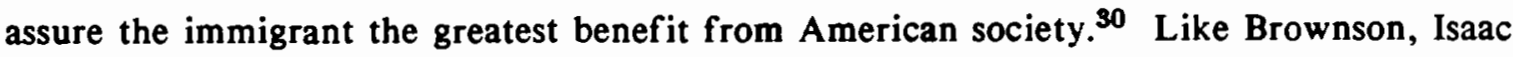
Hecker insisted that immediate assimilation would benefit the immigrant the most. Both men, according to Colman J. Barry, were striving for a "traditional Catholicism formed in an American democratic mold and based on a fusion of all national groups...a religious and national unity among the Catholic immigrants. ${ }^{\text {"31 }}$

Insistence that immigrants adopt American customs and language, consequently meant that they give up their own. Many liberals believed that if the diverse Catholic immigrant groups coming to America were to maintain their separate language and customs, it would clearly lend credence to the prevailing idea that the Catholic Church was a church of foreigners, and that it was, therefore, a menace to the existence of the Republic. These were perceptions that liberals wanted to avoid at all costs.

The alien threat to the United States was not just a protestant perception fueled by fears of a plot by the pope to take over the country. American Catholic liberals were also convinced that the Germans, for example, were out to "Germanize" the American Church. The liberals saw every novel idea, as manifested by the Germans, or the Irish, as a threat to the traditional American way of life. On the other hand there were those American Catholic leaders who firmly believed that assimilation of ethnic minorities had to proceed slowly and carefully. Men such as Bishop John Martin Henni (first German bishop in the United States), Bishop John Nepomucene Neumann of Philadelphia, Archbishop Michael A. Corrigan of New York, and Bishop Bernard McQuaid of Rochester were concerned that the hasty adoption of American ways would lead
29 Gleason 24.
30 Gleason 24.
31 Gleason 66. 
immigrants to lose their faith. The preservation of the faith was their overriding objective. $^{32}$

"Americanization" was, in fact, perceived by these conservatives as a threat to the immigrant's faith. Leaders such as Corrigan and McQuaid maintained that assimilation should take several generations during which, they insisted, the mother tongue would be preserved and the immigrants would continue to live among their own. ${ }^{33}$ They believed that this was how the immigrating Catholics would hold onto their religious beliefs.

German Catholics, as a whole, agreed to just such a policy from the very beginning. They brought an extraordinary loyalty to their religious customs: "sound organizational technique, and a strong community pattern of worship, culture and social action. $^{.34}$ As the number of German Catholics increased in the United States they demanded that the Church allow them language rights, national parishes, and proportional representation in the Church hierarchy in order to preserve their traditional religious observations and their faith. ${ }^{35}$ Assimilation had grave consequences according to Rev. Anton H. Walburg. In The Question of Nationality in its Relation to the Catholic Church in the United States, published in 1889, he wrote: "Denationalization is demoralization....It degrades and debases nature. A foreigner who loses his nationality is in danger of losing his faith and character. ${ }^{\text {"36 }}$

"Language saves the Faith" became the rallying cry of those German Catholics

32 Richard M. Linkh, American Catholicism and European Immigrants (1900-1924) (New York: Center for Migration Studies, 1975) 2.

33 Linkh 3.

34 Gleason 66.

35 Gleason 66.

36 Linkh 6. 
trying to preserve their customs and traditions in the New World. ${ }^{37}$ The continued use of the German language, not only in church but in schools, at home and in newspapers, was seen as the only way to preserve the faith--something that many German immigrants had come to the United States specifically to do.

Otto von Bismarck's Kulturkampf, an anti-Catholic campaign in Germany in the 1800's, practically destroyed papal jurisdiction over German Catholics, abolished religious orders, and made life in Germany unbearable for many Catholics. Due to the Kulturkampf Germans began emigrating in greater numbers to the United States. ${ }^{38}$ Between 1865 and 1900 Catholics made up an average of over $35 \%$ of the total German immigration to the United States. 39

Secular and religious controversies within the American church continued to occur at regular intervals throughout the early 1900's. Yet despite their obvious differences of opinion about ethnic assimilation, both conservatives and liberals did agree on one thing: American nationality and American culture would ultimately prevail. ${ }^{\mathbf{1 0}}$

The battle lines were drawn early in the history of ethnic immigration to America. The battle was at first conceived as a fight between native Americans and non-native immigrants. It became anti-Catholic when more and more Catholic immigrants refused assimilation. Catholicism became the scapegoat. The Church itself became part of the problem and the reaction among German-American Catholics manifested itself in the establishment of Catholic German-language newspapers and periodicals. As part of this reaction the monks of Mt. Angel Priory established a Catholic press. From this press came the St. Josephs-Blatt.
37 Gleason 69.
38 Gleason 67.
39 Gleason 67.
40 Linkh 7. 


\section{CHAPTER IV}

\section{THE YEARS: 1896-1914}

The German-Americans living in Oregon and on the west coast of the United States were affected by the social and political movement of nativism as much as any other immigrant group. Their awareness of the surrounding bigotry and hostility caused them steadfastly to defend and shore up their beloved Deutschtum. The dominant culture in the United States was based on an English foundation. German immigrants were bombarded daily with the Anglo-Saxon point of view and their natural reaction was a promotion of German culture as a counter to the English. ${ }^{41}$

Germans banded together for solidarity. Their beloved institutions such as the Church, Vereine and Logen became safe havens: in Oregon alone between 1857 and 1916, 34 independent social and cultural Vereine existed. ${ }^{42}$ By separating into groups and lodges he maintained contact with that culture which created philosophers, musicians, composers, politicians, and artists whom the world knew and admired. The German immigrant refused to shed his cultural traditions and customs. This did not mean that the German immigrant refused to become an American. He did, however, refuse to lose his Germanness. America was and is a pluralistic society. All types and kinds of people make up the ethnic fabric of this country. The Germans believed that they could become American and still retain an ethnic uniqueness. Thus, instead of being a German in

11 Frederick C. Luebke, Bonds of Loyalty: German-Americans and World War I (Dekalb: Northern Illinois University Press, 1974) 86.

12 Winfried C. Decker, Oregon und sein Deutschtum (New York: n.p., 1920) 168-221. 
America, or an American devoid of traditions, he became an amalgamation, a GermanAmerican.

The hyphenated American -- German-American, Irish-American, etc. -- was someone who had a distinctive ethnic identity. When the term was first used in the 1800 's it was non-perjorative, neutral in tone. There was an implication of a different lifestyle, distinct from that of the native American. ${ }^{43}$ In order to preserve their ethnic uniqueness immigrant groups used many tools in their struggle to slow the integration into American society. One common to all immigrant groups in the United States was the use of the immigrant press.

It becomes apparent to anyone studying the St. Josephs-Blatt that this newspaper was different from the usual ethnic newspaper common in the late 19th and early 20 century. Edward Hunter, in his book In Many Voices: Our Fabulous Foreign-Language Press explains that the articles commonly printed in ethnic papers in the early 19 th century were usually confined to topics and interests peculiar to the particular racial or religious group publishing it. Another historian, La Vern Rippley, in his The GermanAmericans, agrees with Hunter that few if any ethnic papers deviated from the norm of ignoring international news and concentrating on local news and topics relating directly to the interests of their unique readership. ${ }^{44}$ The St. Josephs-Blatt was one of the exceptions.

In 1896 , the eighth year of publication and also the first year available to us for study, the Blatt unveils to its readers what seems to be by then a familiar yet

\footnotetext{
43 Luebke 68.
}

14 La Vern J. Rippley, The German-Americans (Lanham: University Press of America, 1984) 165. 
unconventional format. ${ }^{45}$ The front page is entirely devoted to international news formatted under the daily feature Rundschau. Often leading it off was a poem either by a nationally known poet (more often than not German or an American of German descent) or even a local poet, including members of Br. Cölestin's own order. Br. Cölestin determined the position of information in the Rundschau by order of importance. Naturally it was he who determined what news was most newsworthy for any given week.

In this front page news, various themes were reported upon, some in more detail than others. Within the body of the paper other topics appeared that were more relevant to the lives of the German readers. Page two and three were generally dedicated to serial features, with a weekly feature appearing called Land und Leute. This particular column, divided into Ausland and Inland featured very precise one line or two line descriptions about foreign countries and the United States. Page four was the editorial page. On occasion part of page five was also used for the continuation of the editorials. Aus Welt und Kirche, usually with reports on the religious world, appeared on the last page of the Blatt.

As society slowly proceeded towards war in 1914 the Blatt concentrated its efforts in fighting the nativistic encroachment on German-American rights. The battle to maintain German customs and language in the lives of the readers of the St. JosephsBlatt became more and more important. Deutschtum in America faced strong opposition and the Blatt fought not only the external political forces pressuring German-America to shed all ethnic baggage, but also the internal pressures of the Church to speed-up artificially the assimilation of her immigrant flock.

45 It must be noted here that the first seven years of the St. Josephs-Blatt have been lost. It is impossible to know what was printed during those first years but from the editorials from the first issues of 1896 it can be surmised that the Blatt did not drastically change its goals. 
In the January 3, 1896 issue, the goal and plan of the Blatt was spelled out in the first editorial of the new year. "Wahrheit und Recht" are the key words. ${ }^{46}$ The Blatt vows to take responsibility for the fight for truth and justice. The battle is the "geistige Kampf um die höchsten Güter der Menschheit." ${ }^{m 7}$ The battle lines are drawn between the Church and her foes. The Blatt leaves no room for neutrals in its fight: "Wer nicht mit mir ist, der ist wider mich." ${ }^{48}$

The Catholic press was seen by the editor of the Blatt as a weapon in this spiritual battle. The power of the press, so contends the Blatt, is strong and pervasive; it controls public opinion. Its influence covers every area: politics, art, science, and even religion. It was so powerful that even one's religious faith could be affected by it. The readers are admonished to allow only such newspapers in their homes that recognize their faith and Church, otherwise they become a traitor to the Catholic cause. ${ }^{49}$ The St. Josephs-Blatt, according to its editor, is the German-American's best friend. It holds back all that is contrary to truth and Christian love. The Blatt's weekly search for news that offers the most current domestic and foreign events, its short and long reports relating to history, the Oregon region, and the people, all will teach the reader something of life and nature. ${ }^{50}$ But above all else, the St. Josephs-Blatt will consider the events influencing the religious area:

...die Leiden und Freuden unserer heiligen Kirche und ihres geheiligten Oberhauptes, die Ausbreitung der Religion, die Wirksamkeit des Apostolischen Stuhles, die Thătigkeit der Bischöfe und Priester, der Entwicklung der Missionen

\footnotetext{
${ }^{46}$ Blatt 3 January 1896: 4.

47 Blatt 3 January 1896: 4.

48 Blatt 3 January 1896: 4.

49 Blatt 3 Janaury 1896: 4 .

50 Blatt 3 January 1896: 4.
} 
und Orden--überhaupt was immer die Aufmerksamkeit eines katholichen Christen verdient, dem die Ausbreitung des Reiches Gottes auf Erden am Herzen liegt. ${ }^{51}$

It was in the area of international news, however, that the Blatt distinguished itself from most ethnic newspapers of the times. In its coverage of world news much of the attitude of the editor towards England and English culture was revealed. In 1896 the German-American community still felt a residual resentment towards the Anglo-Saxon element which proposed assimilation and Americanization. ${ }^{52}$

In an article about the English "feindliche Stimmung" against everything German Br. Collestin focused on the anti-German animosity of the British people. ${ }^{53}$ But it was the anti-German attitudes of the British press that especially irritated the Blatt. "Die Deutschen bleiben kühl bis an's Herz hinein gegenüber den Schimpfreden der englischen Presse und den Schmăhungen des Londoner Pöbels." This British enmity towards all things German, as manifested by the British press, is protested over and over again throughout the years $1896-1914$.

The British hunger for extension of their empire around the world is another topic which preoccupies the Blatt at this time:

Die Engländer haben neuerdings wieder eine gewaltige Ausdehnung ihres Machtbereiches vorgenommen, indem sie jetzt auch die ganze südliche Hälfte der Halbinsel Malakka unter britische Verwaltung gestellt haben. ${ }^{54}$

The problems that the British encounter in their imperialistic endeavors are at times gleefully spelled out:

Es thut einem wahrhaft im Herzen wohl, wenn man sieht, wie die

51 Blatt 3 January 1896: 4.

52 Rahill 132.

53 Blatt 17 January 1896: 1.

54 Blatt 24 January 1896: 2. 
selbstsüchtigen, geldgierigen Engländer vor den Buren der Transvaal Republik sich endlich nun doch ducken und etwas vernünftiger werden... ${ }^{65}$

The historic sympathies of the Americans for the British seem to grate on the nerves of the editor of the Blatt when England finally declares war on the Transvaal on October 17, 1899. It is pointed out that of the European powers none is sympathetic to England. There is mention of an "Anglo-Saxon Alliance" between England and the United States, but the Blatt demands that those who consider the United States an Anglo-Saxon nation should look around and learn the "ABC's of politics." Amerikaner...zeigen Sympathie für England....Immer die alte Leier. ${ }^{n 57}$ It is the Americans, points out Br. Cölestin, who always seem to be the one to pull England's "Kastanien" out of the fire when she gets herself into these political problems. It is always her allies that end up winning her wars. "Uncle Sam" and the many "asses" in this country are now supposed to do it.

In the June 4, 1901, issue British imperialism and the prejudice of the British press are again reported. The Boers in the Transvaal are compared with the American Revolutionaries. The American government is a group of "anglophiles" who with their stand on the war will leave a black mark in the history of the United States. According to the Blatt the large newspapers, which are considered predominantly "englandfreudig" report little of the war, and what is reported comes from English sources, and is therefore less than reliable.

The fact that the Blatt was so expressly critical of the British, especially in their endeavors to extend their empire, bears out my contention that the xenophobic attitudes of the American nativist movement had had a deleterious and lasting effect on the

\footnotetext{
65 Blatt 21 September 1899: 1.

56 Blatt 19 October 1899: 1.

57 Blatt 9 November 1899: 1.
} 
attitudes of the editors of the German-American newspapers. Yet it was the antiCatholic prejudices that still existed in the United States that most obviously affected the attitude of the editor of the Blatt.

From the very first issue of January 3,1896 , the articles and the editorials in the St. Josephs-Blatt reflect a concern for the welfare of Catholics in Oregon and the United States. Specific anti-Catholic hate groups, such as the "American Protective Association (A.P.A.)," are condemned in no uncertain terms. In fact, a long article on May 14, 1896, illustrates the Blatt's concern:

"Die Pflichten des deutsch-amerkanischen Katholiken" war das Thema, über welches Msgr. Dr. Schroeder in einem Vortrage den er kürzlich in Cleveland hielt, sprach. Msgr. Schröder legte seinen Horrern an's Herz, gut deutsch zu bleiben, der deutschen Errungenschaften eingedenkt zu sein und die deutschen Sitten und Gebrăuche wie ein Heiligthum zu wahren. Redner schenkte seine Aufmerksamkeit aber auch der A.P.A. dem verbissensten und fanatischsten Feinde der katholischen Kirche in Amerika, die er als unrepublikanisch und als eine Beleidigung der republikanischen Institutionen bezeichnete. "Als Bürger kőnnen wir Republikaner oder Demokraten sein," sagte Dr. Schröder, "das mögen wir halten, wie wir wollen. Wenn ich aber mit zwei Candidaten zu thun habe, von denen der eine meine Sprache und meine Religion respektirt, der andere mich aber meiner religiösen Freiheit beraubt, so stimme ich für den erstern, gleichviel ob er ein Republikaner oder Demokrat....Kein Katholik kann seine Pflicht gegenüber der Kirche ganz und voll thun, der nicht einem katholischen Verbande angehört. Eine Armee wird gegen uns ins Feld gestellt; unsere Pflicht ist es, ihr eine größere Armee entgegenzustellen, um unsere religiöse Freiheit zu vertheidigen--Man soll uns gerüstet vorfinden. ${ }^{\text {58 }}$

This concern for the welfare of German-American Catholics is reflected in the first issue of 1897 when the St. Josephs-Blatt's masthead was changed from St. Josephs-Blatt. Zeitung für Wahrheit und Recht, to St. Josephs-Blatt. Eine Zeitung für das kath. Volk. The emphasis is now on the "Catholic," and from this point the frequency of articles relating to Catholics and German-Americans increases dramatically. As far as the Blatt was concerned the plight of German-Americans and Catholics was one and the same. If German-Americans lost the battle to maintain their culture and language in America, it was feared that the Catholics would surely lose their freedom of religion. 
The columns of the Blatt reflected the German-Americans' desire to be loyal American citizens and still remain German. In 1899, on the occasion of his 70th birthday, Carl Schurz spoke to a packed house of German-Americans in New York City. He made it clear that German-Americans owed their new homeland their fullest devotion; that they must feel American, i.e., politically American. The sooner this process was completed the better. However, according to Schurz:

...diese Verpflichtung schließt keineswegs ein, daß der Deutsche in Amerika von den guten und wünschenswerthen Eigenschaften, die er aus der alten Heimath in die neue mitgebracht hat, auch nur das Geringste aufgeben müsse. ${ }^{59}$

Schurz continues specifically addressing those German-Americans who for political expediency discarded the German language, to admonish them for their foolishness. He describes the German language as a very dear treasure that uncounted thousands sweat in order to learn. "Wer von uns neben der erlernten englischen Sprache die Pflege der deutschen Sprache beibehălt, wird dadurch nicht ein schlechterer Patriot, sondern ein gebildeterer Amerikaner."

When it came to the voting power of German-Americans the Blatt swelled the April 27, 1899, editorial page with a reprinted article from the Katholisches Volksblatt. President McKinley, according to the article, sat in the White House by virtue of the German-American vote. Had they not been solidly behind him, he would not have been there. But the Volksblatt, as well as the St. Josephs-Blatt, was well aware that McKinley, a Republican, dismissed their voting bloc as inconsequential. Despite the opposition of the combined German press, McKinley had appointed a known nativistagitator, a Mr. Powerly, to the influential position of Commissioner of Immigration. The reprinted Katholisches Volksblatt editorial reminded its readers that during the recent rabble-rousing propaganda against Germany, the American government had done nothing 
to discourage those who had insulted and belittled the German people. The Republican

correspondent Major Habercom is quoted:

Die jetzige Administration dankt ihre Erwăhlung, wenn ihre Platform sie nicht allein herbeigeführt hat, in erster Linie den Deutschen! Hat sie aber die Ansichten und Wünsche der Deutsch-Amerikaner in irgend welchem Grade berücksigt? Hat sie sich je mit diesen in Verbindung zu setzen gesucht? Nicht daß ich wüßte. Ihre Politik ist den Deutsch-Amerikanern nicht sympathisch gewesen;...Prăsident McKinley ist immer ein guter Politiker gewesen; als solcher muß er auch jetzt noch wissen, wie gefăhrlich es für irgend eine Partei und einen Kandidaten ist, das deutsche Element herauszufordern. Ohne die Stimmen der großen Mehrzahl der Deutsch-Amerikaner hătte er nie Prăsident werden können; ohne dieselben kann die republikanische Partei nicht siegen, wenn es eine einigermaßen starke Oppositionspartei giebt. ${ }^{60}$

In the last part of the reprinted article from the Volksblatt the paper gives a sad prediction, that unbeknownst to the writer would occur in the near future:

Wir Deutsch-Amerikaner sind Amerikaner, selbst in einem ungerechten Kriege gegen Deutschland würden wir es sein, aber wir würden die Leute dafür bestrafen, die ihn herbeigeführt haben, politisch natürlich; unsere Langmuth ist groß, aber beide haben doch ein Ende und wir kommen dem Ende bedenklich nahe. ${ }^{61}$

The German element in the United States at this time was very proud of its homeland. Despite the growing militarism in Germany, many saw the recent accomplishments of the German government and people as positive. The public in general, however, had changed its mind regarding the German military prowess. In 1871 they had looked at it as a model of efficiency and strength. Now the public was more concerned about Germany's military might. ${ }^{62}$ The Pan-German League had begun activity to promote German ideology. The leaders of the league were quite militant in their endeavors. ${ }^{63}$ Meanwhile the public had become more and more critical of the league and

Blatt 27 April 1899: 4.

61 Blatt 27 April 1899: 4.

62 Luebke 73.

63 Luebke 74. 
Germany in general. Hence the upsurge in anti-German rhetoric referred to by the Katholisches Volksblatt.

In the St. Josephs-Blatt's coverage of national news most of the articles were dedicated to either news of the Catholic Church or news about German-Americans. It was not unusual to see articles about the many German-American societies that existed in the United States. In 1899 a group of 20 German organizations had gathered in Chicago in an effort to express publicly their displeasure with the efforts of the American government to entangle this country in alliances that, according to them, would endanger American prosperity and peace. The Chicago Germans were referring to an incident involving a Captain Coghlan, a commander of the U.S.S. Raleigh. Captain Coghlan, on his return to the United States from action in Manila, enjoyed a small party in his honor. At this party he gave free voice to his feelings regarding the Germans in Manila and especially of one Admiral Dietrich. The Commander of the fleet gave Captain Coghlan a dressing down for his insulting remarks about the Germans and Admiral Dietrich, but President McKinley "gab ihm aber nachher Candy...." It was pointed out that no one was surprised at this behavior since President McKinley and Coghlan were very "chumy" and that "Natürlich, gleich und gleich gesellt sich gern."

The Chicago German-Americans were outraged that their president ignored the insults to their people. In a resolution, issued on April 18, 1899, they let their pride of culture and morals be known:

Wir wollen mit deutscher Ernsthaftigkeit das Beste in unserer nationalen Kultur und Moral, das wir über das Ozean brachten, aufrechterhalten und verpflichten uns deshalb zur Pflege unserer deutschen Sprache, deutscher Sitten und deutscher Geselligkeit und allem denjenigen, was gut ist im deutschen Charakter.

Wir vereinigen uns zu einer Offensiv- und Defensiv-Allianz gegen jede Agitation zur Einschrănkung der deutschen Einwanderung und gegen alle Angriffe auf unseren nationalen Charakter, unsere Ideen und Gewohnheiten. ${ }^{64}$ 
This passage speaks out against the restrictionist immigration policies of the American government that were promulgated during the 1880 's. It was at this time that the American government actively began to lobby for the control of immigration into this country. ${ }^{66}$ German-Americans weathered these efforts by organizations like the American party, the Know-Nothing party, the Ku Klux Klan, and the American Protective Association. ${ }^{66}$ They were not, however, ready to sit back and allow the government to discriminate against them. ${ }^{67}$ The Blatt took it upon itself to protest the politically aggressive rhetoric against Germany. Germany had its faults, naturally, but she was, after all, the source of German culture. When she was ridiculed or insulted, especially by the local press, the Blatt took exception.

One such incident involving the Oregonian illustrates the point. In a St. JosephsBlatt editorial dated May 11, 1899, the Oregonian was taken to task for its anti-German attitude, which according to the editorial was not an isolated occurence. Headlined in the Oregonian as "Germans in the United States" the article among other things takes a small group of Germans living in the United States to task for defending the aggression of the German military in the Phillipines and Samoa:

...The Oregonian's only grievance against the Germans of this country is that some of them, haply they are few, have been beguiled into defense of German aggression towards the United States in the Philippines, and in Samoa, and even into denial of the plainest and most unquestionably attested facts. The course of Admiral Diedrichs [sic] at Manila was one of insufferable arrogance and impertinence. The course of Germany's representative in Samoa has been indefensibly mischievous. To deny the facts is the boldest kind of stupidity. To defend them stops little short of malignity. The Oregonian is persuaded that

65 Rita J. Simon, Public Opinion and the Immigrant: Print Media Coverage, 18801980 (Lexington: Lexington Books, 1985) 13.

66 Simon 13.

67 See Rita J. Simon's book, Public Opinion and the Immigrant: Print Media Coverage, 1880-1980 for more information on the history of immigration legislation in the United States between 1880 and 1980. 
neither denial nor the defense has any considerable following among the Germans of the United States. ${ }^{68}$

The Blatt calls the Oregonian's posture sanctimonious prating (Salbaderei) claiming that the staff at the English-language paper read few if any German-language papers and thus could not substantiate its claims. In fact, the Blatt refutes the story and cites the numerous (24 to be exact) German newspapers it had consulted as proof that the Germans in the United States had never been more united than now, especially in their condemnation of the "gelbe Presse" and its echoers, to which the Oregonian occasionally had to count itself. The editorial in the Blatt ends with a personal message to the Oregonian from Br. Collestin:

Also mein Freund vom Oregonian, nur keine Beweise, die sich auf die gelbe Presse stützen, nur keine petito principii. Damit mogen Sie Suckers fangen aber keinen denkenden Deutschen. Wir sind sicherlich gute Amerikaner, brauchen aber deßwegen [sic] nicht Ja und Amen zu allem zu sagen, was die Regierung oder ihr Vertreter thut. P.B. ${ }^{69}$

It is in the editorials of May 18, 1899, however, that the Blatt chided the Englishlanguage press for its limitations and then eloquently defended German culture to its readers and their children. The Blatt ironically regretted that the editors and the staff of most of the so-called world papers could not understand foreign languages or read foreign newspapers. This was the reason that these papers were so limited and bigoted, and unable to grasp anything that was not patterned after "Yankee-Notions.."70

On the same editorial page the Blatt reiterated its defense of German culture and at the same time bemoaned the lack of understanding the children of German-Americans had towards their heritage. If they knew what the Germans had achieved in the areas of art, science, education, industry, and commerce they would have to be proud of their

\footnotetext{
68 "Germans in the United States," editorial, The Oregonian 6 May 1899: 4.

69 Blatt 11 May 1899: 4.

70 Blatt 18 May 1899: 4.
} 
origins. If the children of German parents learned a sense of decency in school they would perhaps be somewhat more careful in their judgments about their German heritage and perhaps not be ashameed of it. The Blatt was admonishing German-American parents to teach their children about their homeland and origins. ${ }^{71}$

The paper goes as far as applauding the increase in German immigration to this country in 1899. This increase will "...dem Deutschthum helfen." ${ }^{m 2}$ The position of the liberal German-Americans continued to be that they must persevere in their organizing; they must continue to speak German, and they must take care that their children do not forget.

There was a large group of German-Americans who were ashamed of their language, admonished the Blatt. They mimiced everything that was American and in doing so were traitors to their language and German traditions and customs. This could not be condoned. Good German-Americans had to protest anti-German movements and articles. German organizations had to be founded and the established organizations had to be joined.

Br. Cölestin points out that German-American Californians had set a good example by founding a statewide German association:

Kurzum "Vorwärts!" das sei unser Schlagwort, fort mit der alten, elenden Scham, zeigen wir uns als rege, ăchte [sic] Deutsche, die Antheil nehmen zu wissen am Wohl und Wehe des Landes und dabei das alte Land mit seiner schönen Literatur und seinen schönen Gebräuchen und Sitten nicht vergessen! ${ }^{73}$

The Blatt points out that Catholic German-Americans had more reason to follow the preceding advice than the average German-American:

Besonders wir Katholiken haben allen Grunden [sic] das zu thun, damit wir getreu alter Ueberlieferungen, nicht bloß uns, sondern auch unsere Kinder und

\footnotetext{
71 Blatt 18 May 1899: 4.

72 Blatt 22 June 1899: 4.

73 Blatt 22 June 1899: 4.
} 
Kindeskinder in unserem alten, wahren Glauben erhalten und nicht der verwerflichen, auf das Aussterbeetat schon gesetzten Yankee Rasse uberliefern. ${ }^{74}$

The idea that the beliefs of the Yankees were reprehensible was echoed by many Catholic leaders. Some went so far as to maintain that when a German immigrant attempted to take on American customs and the English language too quickly, the first word or phrase he usually picked up was a curse: ${ }^{75}$

Ihr alten, thörichten, anglikanistirten [sic], einfăltigen, amerikanernachahmenden und zipfelkappigen Schlafmūtzen und Hanswürste denkt einmal darüber nach und kommt zu dem Schluß, in Eurer Familie nicht blos [sic] das Englische, sondern auch das Deutsche recht fleißig zu pflegen....Deutsche Sprache, deutsches Fleiß, deutsche Sitten, deutsche Kraft, und deutsche Biederkeit ist es was uns hier ganz besonders Noth thut, und was wir erhalten wollen und müssen....Also es lebe hoch die neuerwachte deutsche Bewegung in unserem Lande vivat, erescat, floreat, ebenso die deutsche Einwanderung. ${ }^{76}$

In the June 22, 1899, issue the strength of German Catholicism worldwide was praised; in Puerto Rico and Cuba German bishops had been named and German Benedictines were active in South America. If the Teutonic race remained true to its traditions, they would be guaranteed a special place in history. "Also, fort mit allem Humbug. Laßt uns stolz sein auf unsere Heimath und nie den Verrăther an derselben spielen. Lieber sterben, als das von den Altvordern Ererbte aufgeben. ${ }^{\text {"77 }}$ Yet in the same issue there appears an article that does not just praise the Germans and their wonderful virtues, but actually looks at them with some objectivity. This article questions whether or not the so-called German qualities such a "deutscher Fleiß, deutsche Redlichkeit, deutsche Gutmüthigkeit, deutsche Treue, deutsche Liebe, deutsche Keuschheit, deutsche Frömmigkeit, deutscher Ernst, deutsches Gemüth, deutsche Gründlichkeit" among others were restricted to Germans. The writer birngs up the German love of alcohol and

\footnotetext{
74 Blatt 22 June 1899: 4.

75 Linkh 7.

76 Blatt 22 June 1899: 4.

77 Blatt 22 June 1899: 4.
} 
their general enjoyment of drinking. All and all, the Germans are viewed with humor and frankness. They are seen as a people with cultural and social problems. To recognize these weaknesses was to be stronger and to that end reveal the real "deutsche Gesinnung, deutsche Treue und deutscher Fleiß."78

The campaign against the anti-German movement that was sweeping across America in 1899 continues with a reminder by the St. Josephs-Blatt of the number of GermanAmericans and Americans with German surnames that had fought and died in the Spanish-American war. The article's conclusion is that the current detractors of the German people have forgotten just how many had died for the United States. ${ }^{79}$

The October 12, 1989, issue of the Blatt appeared with another new masthead. To either side of St. Josephs-Blatt we read: Gott zur Ehr'/Dem Bösen zur Wehr'! and Der Wahrheit zum Schutz/Der Lüge zum Trutz!. Under the banner there is now: Familien Zeitung, für alle Stände zur Erbauung, Belehrung und Unterhaltung. A family newspaper for the edification, instruction and entertainment of all classes seems to sum up the Blatt's goal of teaching its readers and protecting their rights as Catholics and Germans. Br. Coblestin as the editor of the Blatt took his mission seriously to heart. The barrage of articles on the importance of German culture and of maintaining the German language continued throughout the years preceding the outbreak of war in 1914.

In 1901, the advantages that German-American children who spoke both German and English were noted. ${ }^{80}$ The fact that the nativist movement was not yet dead is also noted in the Blatt in 1901 . The "anglo-amerikanische Nativistenbande" applauded the police in Yonkers, New York, when they used an antiquated law against GermanAmericans celebrating with beer and good music. But, reports the Blatt, when the plice

78 Blatt 22 June 1899: 6.

79 Blatt 7 September 1899: 6.

80 Blatt 28 May 1901: 4. 
tried to stop a baseball game on Sunday in Yonkers, the nativists screamed "Vergewaltigung!" The Blatt answered with, "Ja, Bauer, das ist ganz was Andres."

The March 1, and March 8, 1907, issues of the Blatt boasts a two part article entitled: "Die deutsche Sprache." This article was the largest printed by the St. Josephs-Blatt in the years 1896-1914. As in previous articles on the German language, the editors extol the virtues of maintaining the mother tongue by German-Americans and their children. Those philosophers and writers who had used German as their medium of expression were legion, and to lose that heritage would be to lose one's soul.

The May 31, 1907 issue also informs the reader about the circulation of the Blatt. Average circulation during May 1907 was as follows:

May 3, 19,050 copies

May 10, 19,150 copies

May 17, 19,400 copies

May 24, 19,600 copies $^{81}$

The figures were verified and sworn to by a notary public by the name of Dr. Urban F. Fischer, Mt. Angel, Oregon. The entire piece was printed in English. On September 27, 1907, the circulation of the Blatt was listed as 20,240 copies. $^{82}$

The January 3, 1908, issue of the Blatt illustrates one little known function of the paper. On page two of this issue an ad appeared which illustrated one of the secondary raisons d'etre for the St. Josephs-Blatt: "Auskunftsbureau für Einwanderer in Mt. Angel, Oregon." Addressed specifically to the "deutscher katholischer Heimsucher" who might be in the market for a farm, a place of business, a hotel, or a smithy, prospective immigrants are coaxed into coming first to Mt. Angel to view the town and the surrounding area. The ad continues: "Es befindet sich da die größte und blühendste deutsche katholische Gemeinde des Westens, berühmt durch ihre vorzüglichen katholischen

81 Blatt 31 May 1907: 4.

82 Blatt 27 September 1907: 3. 
Kirchen und Schulen. ${ }^{n 83}$ The ad writer proceeded to compliment the fertility of the soil and the healthiness of the climate of Oregon. ${ }^{84}$

This type of ad appeared only once in the years studied, yet throughout the history of the Blatt the idea of promoting the relative advantages of Oregon and the entire west coast was an ever present one. This could in itself be a fascinating subject for another thesis, but let it suffice to say that one of the Blatt's goals was to be sure that the newly arrived immigrant would know that it would behoove him to continue westward once he had landed on the shores of the New World.

The January 24, 1908, issue begins with a poem titled "Hymne an Amerika" (no author listed) which praises the glories of America: blessings from God; rich, fertile land with riches beyond imagination. The people are said to have a certain boldness that in ways relates to Germany (Vaterland). America will protect you with a strong hand:

"Das Land, das schöne, große --es heißt Amerika!"85

In October of 1908 the St. Josephs-Blatt addresses, in an editorial, the issue of German-Americans and their contributions to the growth of the nation:

Die meisten unserer Geschichtsbücher für Schulen wurden mit großer "anglosăchsischer" Hinneigung geschrieben. Jeder von Englăndern und deren Nachkommen ausgeübte Einfluß wurde in übertriebener Weise hervorgehoben, indes alle anderen Nationalităten ignoriert wurden. Dies ist nicht billig. Die Ver. Staaten hătten ihren gegenwătigen [sic] Stand als Nation nie erreicht, wenn keine Kelten und Teutonen mitgewirkt hătten. Gebet den Deutschen Kredit für den ihnen beim Aufbauen eines grossen Landes zukommenden Anteil. ${ }^{86}$

\section{Blatt 3 January 1908: 2.}

84 Father Martin, archivist at Mt. Angel in 1987, spoke of this goal of the Blatt to draw people to Oregon. As part of the national trend in the late 1890's and early 1900's a number of German-Americans advertised in German-language papers trying to entice German settlers to a particular part of the country. Father Martin mentions one Mr. Fuchs, a real estate agent, whose business it was to find people interested in buying farms, small businesses, etc., in Oregon, Idaho, and Kansas.

Blatt 24 January 1908: 1. 
Again we hear complaints of the American prejudice towards the Anglo-Saxons. The bigotry facing Catholics in the United States in 1908 was indicated by Br. Cölestin in another editorial. He theorized about the wonderful idea of electing a Catholic as President of the United States, but recognized the reality of the situation when confronting the "immer noch herrschende unverantwortliche Bigoterie" which would completely rule out the mere possibility of a Catholic president ${ }^{87}$ No one, however, recognized more the need to do battle against these bigoted ideas than did the $\mathrm{Br}$. Collestin. In the very same issue that the idea of electing a Catholic president is dismissed with annoyance, the editor reprints a major piece calling for resistance to the apathy and ennui that seemingly had taken hold of the German Catholic population in Portland. Quoting a speech by one Fr. Schmidt, O.P., delivered at a German-American Celebration of the Family on November 16, 1908, the editor stresses the need to participate actively in resisting, instead of merely discussing.

In the article a story is told of a sick man. He was freezing and going hungry when the neighbors finally found him and took him to the doctor. The neighbors asked how they might help him. No one, however, could figure out what he needed. Arguments over just what to do for him ensued. No solution could be found, until finally one neighbor suggested that all he needed was a warm room and good food. Finally, he began to heal. It was this unceasing debate as to what was wrong and what do do to save the "Deutschtum" in Oregon that was in fact killing it, according to Fr. Schmidt:

Die Leute sagen oft: "Die Deutschen sterben aus. Das Deutschtum hier zu Lande leide an Mammonismus, Lungenschwindsucht und Auszehrung." Man hat schon alles mögliche versucht, um dem kranken Mănnlein, das doch einst ein starker achtungsgebietender Mann gewesen, wieder auf die Beine zu helfen, doch alles scheint umsonst. 88

\footnotetext{
87 Blatt 4 December 1908: 4.

88 Blatt 4 December 1908: 5.
} 
Fr. Schmidt continues, suggesting that despite the founding of different Vereine, (Grülliverein, die Hermannssöhne, Brionsängerbund, etc.), which purported to subscribe to German ideals, Deutschtum still continued to die out. Those attending Fr. Schmidt's speech were asked if that was what they wanted:

...dann höret auf mit deutschen Festen, mit deutscher Sprache, dann verleugnet Euere deutsche Herkunft und vergesset die großen Kulturtaten, die Eurere Văter in diesem Lande, wie in der alten Heimat vollbracht haben. ${ }^{89}$

The listeners are challenged to halt this decline of Deutschtum:

Dann werdet Ihr mir auch ein geneigtes Ohr schenken, wenn ich bei dieser Festfeier einige Vorschläge mache und Mittel empfehle, die ganz sicher dem schwachen Mănnlein wieder auf die Beine helfen....Ihr werdet nicht blos [sic] die Vorschlăge annehmen, sondern von den Worten zur Tat schreiten, zur Lösung der großen Aufgabe, die den deutschen Katholiken in Portland abliegt. ${ }^{90}$

The first and "most important" means to save Deutschtum in Portland was the "German-Catholic press." The newspaper, according to Fr. Schmidt, had become a powerful tool, which helps form the world outlook of its readers, and its power is so pervasive that some dare not even think except in the way the paper wrote. ${ }^{91}$ When a reader is asked why he or she thought a particular way, Fr. Schmidt insists that the answer will be: "Es stand in der Zeitung; es muß wohl richtig sein." Fr. Schmidt not only considers the press a "Weltmacht" but more importantly a "Volkschule für die Erwachsenen," where adults get their social, political, and religious education.

The fact that the German-Catholics know this about the press doesn't seem to matter. According to Fr. Schmidt they still do not use it to its fullest advantage. He cites the St. Josephs-Blatt itself as an example of a good German-Catholic newspaper, which although published for almost 20 years, still had not reached the power it could or

89 Blatt 4 December 1908: 5.

90 Blatt 4 December 1908: 5.

91 Blatt 4 December 1908: 5. 
should have. The fault lies not with the Blatt, but with its readers, who do not spread the word. The readers are urged to subscribe to the Blatt, and to use it to their fullest possible advantage; to teach the German language and to awaken German ideals in its readers. Where it was read by children and adults, the fear of the diminishing or death of the German Catholic spirit would disappear. ${ }^{92}$

Fr. Schmidt concludes his speech on the German-Catholic press by showing one side of his obvious prejudice for just such an ethnic and religious press. He intimates that although by reading only the German-Catholic press the reader may be getting only one side of the story, that is not a problem, and there are practical reasons why Catholics should read only Catholic papers:

Ich frage, können andere Blătter, die nicht auf unserem deutschen, kathol. Standpunkt stehen, können die uns verstehen oder unserer Sache gerecht werden? Bei der herrschenden Stimmung gegen das deutsche Volk, bei der natürlichen Abneigung, Geringschătzung und Mißgunst, die man leider im Stande der unbeschränkten Freiheit findet, ist es ganz und gar unmöglich, daß andere Blătter uns gerecht werden oder auch nur ohne Vorurteil behandeln....Also Ihr deutschen Katholiken, in Euer Haus gehört ein deutsches, katholisches Blatt, das St. Josephsblatt, das ist das erste wirksame Mittel um dem [film unreadable] Korper wieder Leben und Geist zu geben. ${ }^{93}$

In 1908, however, not all ethnic Catholics reacted positively to the organization of their countrymen or immigrants in general into hyphenated ethnic-social or ethnicpolitical groups. The Blatt's editor questions the validity of one Irish-Catholic priest's denouncement of the hyphenated Catholic. Rev. Kelley, speaking before a congress of missionaries, caused quite a bit of controversy and rebellion among the ethnic Catholics in Chicago, when he denounced the Irish-Catholic and German-Catholic as entities. He believed too much emphasis was being placed on politics and not enough on saving souls. He especially thundered against Catholic organizations which emphasized "Selbstsucht und 
Vergnügungssucht." ${ }^{m 4} \mathrm{Br}$. Colestin found it hard to agree with Rev. Kelley since he knew "mehrere große Organizationen, die keinen Tadel, sondern Lob verdienen." 95 The editor punctuates his point by printing the conclusion of Fr. Schmidt's speech before the German Family Celebration on November 16, 1908. The topic of this part of the speech addresses the same issue --the life of ethnic Catholic organizations. Fr. Schmidt contradicts Rev. Kelley's thesis:

Wir brauchen ferner Vereine, wenn wir etwas bedeuten und erreichen wollen; wir brauchen starke, blühende, opferwillige Vereine. Der einzelne Mann gilt im offentlichen Leben eine Null. Hier kommt alles auf die Massen an; die Massen werden nur durch andere Massen überwunden. ${ }^{96}$

Fr. Schmidt then continues by illustrating his point with reference to the trend in the early 1900's of German-American Catholics joining non-sectarian "Logenvereine":

Das wissen die Gegner unseres christlichen Standpunktes wohl und darum halten sie eine so rege Agitation unter neuen Einwanderen, um sie gleich für irgend einen Logenverein zu kapern. ${ }^{97}$

His point is that there were plenty of groups and organizations existing in Oregon and the rest of the United States, but not all were worthy of validation by the Church or by German-American Catholics. Not all worked for the "deutsche Ideale," nor did all agree with the "religiose Ueberzeugung" of his Catholic audience. 98

In the same vein, the Blatt prints in the February 5, 1909, issue an article sent in from Cincinnati, Ohio, called "Totengräber der deutschen Sprache." Again the issue revolves around the importance of German-Catholic Vereine and their function of furthering both Catholic and German ideals. It should again be remembered that the two

94 Blatt 11 December 1908: 4.

95 Blatt 11 December 1908: 4.

96 Blatt 11 December 1908: 5.

97 Blatt 11 December 1908: 5.

28 Blatt 11 December 1908: 5. 
are thought of in tendem. Without the German language and German customs, the German-American Catholic would lose his faith. Faith and language are intrinsically connected with one another. The "Totengraber" are described as infiltrators of the German-Catholic Vereine who are now boldly agitating for their agenda to "verenglisieren" the Vereine. Indeed, the movement to allow English to be spoken in Vereine all over Cincinnati was spreading, even though, according to the article, the impetus seems to be laziness on the part of the members; they are too lazy to learn German in school or too lazy to speak it. Yet, according to Br. Cölestin even more insidious than that was the other shadowy side of the problem; one that was even more telling of the youth of the times. It is:

...die Rücksichtslosigkeit der Jüngern gegenüber ihrer Eltern, das schon mehr Mißachtung bezw. Respektslosigkeit als etwas anderes genannt werden muß....Ist es Liebe und Achtung vor den Eltern, wenn die Jungen in brüsker Weise verlangen, daß in Kirche und Schule nur Englisch gesprochen werden sollte? ${ }^{99}$

The German language was of paramount importance to German-American Catholics according to many other articles in the Blatt. In 1909 the paper celebrates its readers' mother tongue by publishing a poem entitled "Meine Muttersprache":

Ich hab dir ins Aug' geschaut So tief bis auf den klaren Grund; Ich habe selig jedem Laut

Gelauscht von deinem süßen Mund.

Ich ging an deiner Hand den Pfad, Und leuchtend kam das Glück mit dir; Aus deinen Worten sproß die Saat

Des Glaubens in der Seele mir.

Noch ahnt' ich kaum, wie reich und schön, Doch o wie lieb du warst, wie lieb!

Und deiner Liebe Goldgetön

Zum Einklang weckte Trieb und Trieb.

Vertraut wie in der Kinderzeit Sprichst du noch immer Trost mir zu: Dein Sehnen mein, und dein mein Leid, 
O Seele meiner Seele du!

Und wenn ich bete, bebt dein Laut, Und wenn ich singe, singt dein Mund, Und wenn ich sinn' und trăume, schaut

Mein Herz in deins bis auf den Grund.

Und stockt dereinst das milde Blut, So drückst du mir die Augen zu,

O Mutter, Mutter, lieb und gut,

Mein Stolz und Glück, mein Eigen du!

J. Rothensteiner ${ }^{100}$

The poem clearly illustrates the connection felt by so many German-American Catholics at the time between their language and their faith. One notes particularly the second verse, lines 3 and 4: "Aus deine Worten sproß die Saat/Des Glaubens in der Seele mir."

With the language comes Faith and from the fifth verse, line 1, comes: "Und wenn ich bete, bebt dein Laut." Both quotes verify the German-American Catholics' belief that with their mother tongue comes faith; that to maintain their langauge in their new homeland would help them retain their faith; that in losing their language they will lose their faith. This sentiment is sounded so of ten in the Blatt and in the writings of the time that it becomes a rallying cry for the readers of the Blatt.

An illustration of this premise of "language means faith" are the many articles printed in the St. Josephs-Blatt from its earliest years up through the early 1900's on the meetings of state organizations of German-American Catholics called Katholikentage. ${ }^{101}$ A Katholikentag was a convention of German Catholics, both clergy and laity, in which the participants discussed and debated the best approach to safeguarding their religious rights and the best approach to a successful cultural, civic,

100 Blatt 2 July 1909: 3.

101 Blatt 9 July 1909: 2. 
economic, and social life. ${ }^{102}$ In the Katholikentag held on April 8, 1899, according to the Blatt, the convention passed resolutions declaring their desire to remain firm on Catholic faith, on the German language and German customs.

"Language saves faith" was the slogan of many German-American religious leaders, Protestant and Catholic, in the United States. ${ }^{10 s}$ To most, the adoption of the English language and American customs was a desirable goal, but it needed to happen slowly. ${ }^{104}$ Since German immigrants generally lived in German speaking communities, their religious observances were in German. In order to keep their children in the fold the GermanAmerican Catholics believed they needed to teach their children their mother language. This required Catholic schools; schools where German was the common language of instruction. 105

The Katholikentage would continue in the United States with the idea in mind of bringing together "Katholiken deutscher Zunge" until the United States entered the war against Germany. ${ }^{106}$ Their purpose continued to be a combination of 1) stressing the use of the German language as a means to maintain the Catholic faith among GermanAmericans and 2) continuing Christian social reforms in the United States. "Unser oberster Hirt Pius...erwartet...von der tatkrăftigen, einmütigen Mitarbeit der Laien die 'Wiederherstellung der Reform der Welt in Christo!'m107

102 Colman James Barry, The Catholic Church and German-Americans (Milwaukee: Bruce, 1953) 23.
103 Barry 10.
104 Gleason 69.
105 Luebke 36.
106 Blatt 9 July 1909: 2.
107 Blatt9 July 1909: 2. 
In the years 1910 to 1914 many editorials in the Blatt dealt with Catholicism in the United States but fewer and fewer with the German language or culture. However, in the July 8, 1910, issue Br. Cölestin began the front page Rundschau with an article that ostensibly celebrated the 4 th of July. In fact, he turned the article into an apology about immigrants and their contributions to the growth and prosperity of the United States:

Ob allerdings die Freiheit, welche der Verfasser und die Unterzeichner der Unabhăngigkeits-Erklărung meinten, wirklich uns erhalten geblieben ist, das ließe sich billiger Weise bezweifeln. Es gibt hier nur zu oft Ereignisse, welche dartun, daß die gleiche Freiheit und das gleiche Recht für alle in mehr als einer Beziehung ein leerer Wahn sind, der sich leider nicht erfüllt hat. Es gibt manches in unseren sozialen und Erwerbs-Verhăltnissen, was einer gründlichen Remedur bedarf, wenn ein ernster Konflikt vermieden werden soll. Eines ist aber unbestritten, nämlich das Verdienst der Einwanderer an der Entwickelung [sic] der Ver. Staaten; die Stolze Columbia verdankt sehr viel der Treue und dem Fleiße ihrer Adoptivkinder. Während die Bürger der Vereinigten Staaten schon von der Natur in so überaus reichem Maße begünstigt werden, hat zu ihrem heutigen Reichtum, ebenso wie zu ihrer Macht und Weltstellung, das alte Europa in einem Maße beigetragen, das in der Geschichte einzig dasteht. Europa gab Amerika das größte Geschenk, das jemals seit Urzeiten einem Reiche gemacht worden ist, ohne dafür anderes als Undank zu ernten. Ohne dieses dafür anderes als Undank zu ernten. Ohne dieses Geschenk wüßten die Amerikaner nichts mit ihren Naturschătzen [sic] anzufangen, sie würden unbenutzt daliegen, und es erginge ihnen wie jenem Goldsucher, der in der Wildnis Millionenschătze findet, und doch Arbeitskräfte, um das Land zu entwickeln, um seine Naturschătze zu heben, zu verarbeiten und damit auch auf dem Weltmarkt zu verwerten....

The editorial continues.

Fünfzig Jahre lang dauerte dieser Menschenstrom, und er ist heute eher noch im. Steigen als im Versiegen begriffen, er erreicht jetzt jährlich dreiviertel bis zu einer Million. Seit Jahrzehnten verlassen Tag für Tag, Sommer und Winter durchschnittlich ein bis zweitausend Menschen die heimatlichen Gestade, um in dem gesegneten nordatlantischen Dorado ihr Glück zu versuchen und damit die Entwicklung und den Reichtum Amerikas zu fördern.

Das ungeheure Opfer, das die alte Welt der neuen mit diesen 20 Millionen Menschen gebracht hat, wird in seiner ganzen Große viel zu wenig in Betracht gezogen. Ebenso bleibt es bei der Beurteilung Amerikas gewöhnlich unbeachtet, daß zum grőßten Teil Europa das neue Amerika geschaffen hat. Jede Mutter weiß, welchen Kummer, welche Sorgen die Erziehung eines Kindes ihr bereitet. Jeder Vater kennt die empfindlichen Kosten, die ihm das Großziehen eines Knaben in den ersten zwei Jahren seines Lebens verursacht hat. Werden durchschnittlich nur einige hundert Mark jăhrlich angenommen, so erreicht der Gesamtbetrag für Unterhalt und Erziehung, mit Zinseszinsen gerechnet bei jedem Mann in seinem fünfundzwanzigsten Lebensjahre etwa 20,000 Mark. Bei 20 Millionen also die gerade unfaßbare Summe von 400 Milliarden! 
Gerade in dem Zeitpunkte, wo diese Millionen Menschen in die Lage gekommen waren, das in ihnen angelegte Kapital zum Besten ihres Heimatlandes durch eigenen Tătigkeit zu verzinsen, verließen sie dieses und führten so das Kapital der neuen Welt zu, ohne daß diese auch nur das Geringste dafür geopfert hătte. Europa hatte die Ausgaben, Amerika den Gewinn.

Zum weitaus grőßen Teil waren diese Menschenmassen für die ihnen in Amerika erwachsenden Aufgaben besonders befăhigt, denn es gehŏrt för einen jungen Mann nicht wenig Tatkraft, Entschlossenheit und Wagemut dazu, die gewohnten heimatlichen Verhăltnisse mit ganz neuen in einer fremden Welt zu vertauschen, die Fahrt über das Weltmeer zu unternehmen und in einem Lande, dessen Sprache er nicht spricht, und dessen riesengroße Verhältnisse ihm unbekannt sind, sich ein neues Leben zu schaffen.

Diese 20 Millionen, zu denen im Laufe der verflossenen fünf Jahrzehnte noch Millionen Nachkommen gelangten, die in den Bergwerken die mineralischen Schătze zu Tage förderten und die großen Prărien des Westen besiedelten --eine Armee von Industriesoldaten und Bauern, wie es nie eine größere mit segenreicherer Tătigkeit gegeben hat. Die Fremdenhasser mögen diese Tatsachen beherzigen. 108

Obviously the nativist backlash against the immigrant had not completely subsided, although for the most part few if any other articles in 1910 mention the nativist problem. In February of 1911 the Blatt shows its readers a convincingly fair side of its editor's personality. Despite Br. Colestin's strong convictions and beliefs regarding the wounds inflicted on the immigrant Catholic in the United States by the American nativist movement, he takes great care in writing the Rundschau on February 24. A Catholic newspaper, the Indiana Catholic suggests that the song "My Country 'tis of Thee" ("Heil dir, Mein Vaterland") should not be sung in Catholic societies, supposedly because its contents injure Catholic sensibilities. The Indiana Catholic insists that the song, written by a Methodist minister, was introduced in the "Know-Nothing" era in order to replace the "Star Spangled Banner" as the national anthem. The mention of the pilgrim fathers, according to the Indiana Catholic, sounds uncomfortable to Catholics. The melody, contines the newspaper report, is the same as that of the "Konigshymne" of England and reminds one of tyrannical monarchism. It is not the national anthem and therefore should not be sung by Catholics. 
Br. Cőlestin's responded: "Echter Blödsinn!" and "überspannter Fanatismus." He categorically states that 1 ) there is no recognized national anthem in the United States (the "Star Spangled Banner" was declared the national anthem by an act of congress in 1931); 2) the "Star Spangled Banner" refers too much to war and blood and doesn't fit with the peace loving American people; 3) republican tyranny is more to be feared than a monarchy; and 4) it doesn't matter that a Methodist minister wrote "My Country 'tis of Thee"; there is no trace of confessionalism in it. Br. Colestin ends the article with the admonition that such bigotted nonsense by Catholics should be avoided. It is this type of groundless fanaticism that gives the enemies of the Church the fuel they need to brand Catholics as "unpatriotic" and "inferior," argues Br. Collestin. Catholics complain of "Verfolgung" and then give their enemies the grist for the mill. ${ }^{109}$

The Blatt's defense of the German-American contribution to the life of the United States is again put forward in April of 1911. This time Br. Cölestin editorializes:

Kein anderes Element in der kosmopolitischen Bevölkerung der Ver. Staaten trägt soviel bei, wie das deutsch amerikanische, zur Tüchtigkeit, zu dem industriellen Fleiß und zu dem unermüdlichen Fortschritt unseres amerikanischen Lebens. Unsere Vaterlandsliebe, unsere Freiheit, unsere humanen Institutionen und unsere warme Menschenliebe sind unverkennbar deutscher Abstammung und sind auf das deutsche Blut zurückzuführen, von welchem ein so reichlicher Teil in unsern Adern pulsiert. Nimm den deutschen Einfluß von unseren amerikanischen Institutionen und die Fundamentaleigenschaften des amerikanischen Volkscharakters werden einer raschen Wandlung unterliegen. Deutsche sind hier keine Fremden --sie sind Amerikaner. ${ }^{110}$

A June 9, 1911, editorial continues his debate on the importance of language and faith. This editorial makes Br. Colestin's feelings clear to all who read it; he is definitely an advocate of natural assimilation of the Catholic immigrant, and an opponent of Americanization:

Es gab eine unglückselige Zeit, wo man dem Einwanderer geradezu das Recht abgesprochen hat, in seiner Muttersprache das Wort Gottes zu hören; das

109 Blatt 24 February 1911: 1.

110 Blatt 14 April 1911: 4. 
Englische mußte genügen. Daraus entstanden fur die Kirche große Verluste. Heute sieht man den Fehler ein. Die Reorganisation der kath.

Kolonisationsgesellschaft kann als Beweis dafur gelten. Sie will nicht nur die Einwanderer mőglichst in der Năhe von Kirche und Schule ansiedeln, sondern sie nach Moglichkeit mit Priestern versehen, die ihrer Sprache măchtig sind. Die Verschmelzung der verschiedenen Nationalităten wird sich naturgemăß vollziehen; es ist ein Frevel gegen eine von Gott gewollte Ordnung, diese Verschmelzung mit Gewalt durchzuführen. ${ }^{111}$

The Blatt brings the message of the good immigrant closer to home when in an editorial in July 1911 American Deutschtum is recognized:

Eine Anerkennung des amerikanischen Deutschtums schrieb Oberleutnant J.A. Watrous (microfilm was obscured and the spelling may be wrong) in einem Artikel des Chicago Record Herald, welcher sich mit der Einwanderungsf rage befaßt. Es heißt allda: "Man betrachte die Millionen Deutsch-Amerikaner. Sie haben auf allen unseren Schlachtfeldern mitgefochten; sie haben Milliarden zu unserem Nationalwohlstand hinzugefügt; sie haben alle guten Interessen im Verein mit allen anderen Klassen befordert; sie gehören mit zu den besten Bürgern des Landes. Man denke nur an General von Steuben, welcher Washington in einer kritischen Zeit unschătzbare Hilfe leistete. Herr Eingeborener, begehen Sie nicht den Irrtum, daß dieses Land den Deutsch-Amerikanern etwas gegeben hat, das sie nicht wohl verdient haben. ${ }^{112}$

As one can see, the nativist intrusion and the subsequent comments by the Blatt were few and at this time far between. However, as in 1887, 1889, 1902, 1906, and now in 1912, the effort to enact a literacy test to be used as a weapon against a new influx of immigrants into the United States became a central issue. The Blatt reports on March 20, 1912, that the House committee for immigration chaired by Burnett of Alabama had introduced a new literacy test bill. According to the Blatt Burnett was eager for a reduction in immigration. Br. Colestin does, however, give the literacy test bill its due in that it didn't go as far as the previous bill introduced by Senator Lodge. Burnett's bill would allow those passing the test to bring in family members who did not pass it. The Blatt also notes that the Burnett bill would exempt those immigrating to this country because of religious persecution. The final word on the bill by the Blatt is that the

111 Blatt 9 June 1911: 4. 
Democrats are opposed. ${ }^{113}$ The Blatı's position opposing the Burnett bill is clearly stated in an April 5, 1912, editorial:

Die Nativisten behaupten, der Bildungstest habe seinen Hauptgrund darin, daß die ungebildeten Einwanderer in erster Reihe für die Vermehrung des einheimischen Verbrechertums verantwortlich seien. Ein Beispiel aus Pennsylvanien beweist das Gegenteil. Laut dem eben im Druck erschienenen 42. Jahresbericht des Arbeitshauses in Allegheny County, Pa., wurden im verflossenen Jahr dieser Strafanstalt insgesamt 4171 Uebeltăter eingeliefert, von denen 2473 oder 66 Prozent in Amerika und 1428 oder 34 Prozent im Ausland geboren waren. Rechnet man die Englånder, Irlănder, Schotten, Waliser und Canadier von der Gesamtzahl der Eingewanderten ab, so verbleiben 991 Auslănder oder nur 24 Prozent. Noch günstiger stellt sich das Verhăltnis in der Zusammenfassung aller Jahre, die seit der Gründung der Anstalt verflossen. In diesen 42 Jahren wurden insgesamt 148,758 Personen eingeliefert, von denen 95,784 oder 64 Prozent auf das Ausland entfielen. Mit Ausschluß der Irlănder, Englănder, Schottlănder, Waliser und Canadier hatte das Arbeitshaus seit 1869 nur 21,061 Ausländer oder 14 Prozent aufzunehmen. Und unter diesen befanden sich nur 8199 Deutsche oder 5 1/2 Prozent. Das sollten sich die Nativisten hübsch hinter die Ohren schreiben! ${ }^{114}$

Despite the occasional mention of the nativists and the literacy test bill, the Blatt's concern with the national elections of 1912 was based more on other national problems such as anti-trust and the Tariff acts. The Blatt devoted numerous columns of the Rundschau on the front page as well as a number of editorials throughout 1912 to the battle for the Republican and Democratic nominations for the Presidency. The fact that Theodore Roosevelt lost the Republican nomination to Taft and Roosevelt's subsequent nomination as the candidate of his own third party, the "Progressives," was well covered by the Blatt.

The control of immigration through passage of immigration laws did not itself preoccupy Br. Cölestin, as one might have thought. The nativists and their campaign to restrict immigration were looked upon as problems to be treated with careful thought and organized opposition. 
The June 20, 1913 Rundschau covers another resurgence of congressional

immigration restrictionism. This time an anti-immigration bill was introduced by

Republican Senator Dillingham from Vermont. The Blatt seems to consider the bill

another wayward nativistic attempt to restrict immigration, but sees it as a dangerous

bill with a good chance for passage:

In der Dummheit ist eine Zuversicht, woruber man rasend werden kőnnte. Hat da Bundessenator Dillingham, der Mann mit den großten Kartoffeln im Staate Vermont, eine Vorlage eingereicht zur Beschrănkung der Einwanderung. Daß Dich das Măuslein beiße! Es ist leider wahr, die Feinde der Einwanderung haben die năchst gebotene Gelegenheit ergriffen, um im Kongreß eine Bill zur Beschrănkung der Einwanderung durchzusetzen. Bei der Abstimmung über die nach ihrem Urheber, dem demokratischen Abgeordneten Burnett von Alabama, benamsten [sic] nativistischen Einwanderungs-Bill hatten dei Feinde der Einwanderung im vorigen Kongreß eine solche Macht zu entfalten vermocht, daß eine neue Bill von gleichen Tendenzen wie die von Präsident Taft vetierte in dem neuen Kongreß wohl Aussicht auf Annahme haben dürfte. Dieses um so mehr, da die Zahl der republikanischen Stimmen, die vom vorigen Kongreß gegen die Burnett-Bill agbegeben [sic] wurden, bedeutend weniger geworden ist und von den Demokraten, die in diese Kongreß eingezogen sind, viele mit den Zielen und Zwecken einer Bill wie der Burnett'schen einverstanden sein dürften. Was das Reprăsentantenhaus anbetrifft, so dürfte eine Bill nach Art der jetzt von dem einwanderungsfeindlichen republikanischen Senator von Vermont eingebrachten, mit Bestimmtheit auf Annahme zählen kőnnen....

Br. Collestin reminds his readers that such a bill must be opposed and that it is the repsonsiblity of everyone to do so:

Weil die Chancen entschieden für die Annahme einer Bill wie der jetzt von Senator Dillingham bevaterten sind, kann eine Agitation gegen diese oder ăhnliche Einwanderungs-Bills nicht früh genug in Angriff genommen und nicht energisch genug betrieben werden....Die neue Dillingham-Bill hat vor der BurnettBill und ăhnlichen früheren Einwanderungs-Bills den einen Vorzug, daß der Zweck deutlich ausgesprochen ist. Von dem Bildungstest in der Burnett-Bill, der nur als ein Mittel zur Beschrănkung der Einwanderung gedacht war, wird in der neuen Bill abgesehen und es wird anstatt dessen klipp und klar bestimmt, es sei die Einwanderung der verschiedenen Volksarten dahin zu beschrănken, daß in einem Jahre nicht mehr als zehn Prozent der von solcher Volksart in den Ver. Staaten anwesenden Elemente zugelassen werden dürfen....Die Dillingham-Bill ist denn auch, wenn sie auch verschiedene Nationalităten gar nicht treffen würde, als eine einwanderungsfeindliche Maßnahme zu betrachten und zu behandeln....Gegen die Dillingham-Bill sollte wie gegen jede andere nativistische Einwanderungs-Bill eine rege Agitation eingeleitet werden, weil sie den Interessen des Landes zuwiderlåuft, weil sie gemeinschădlich ist, weil sie unnőtig ist, und weil sie im Widerspruch steht mit dem Geboten der Menschlichkeit, die bis dahin in den Ver. 
Staaten als eine Tradition behandelt worden ist und an der nicht gerüttelt werden sollte, so lange keine eiserne Notwendigkeit hierfür vorhanden ist. ${ }^{115}$ 


\section{CHAPTER V}

\section{THE WAR YEARS: $1914-1917$}

The St. Josephs-Blatt's battle to maintain the German language and preserve German culture in the lives of German-Americans in Oregon was waged against a foe which the German-American editor was hard pressed to identify in a physical sense. The enemy of the German-American was an idea. Immigrants were the object of irrational fear. They were the scapegoat for the lack in others, and for their enemies' failures and inferiorities.

On June 28, 1914, another era of fighting was thrust upon the German-American. Again the enemy was an idea: the hysteria of prejudice, irrational distrust and unwarranted cultural bigotry that faced the German immigrant with the advent of the Great War. This chapter focuses on the war years 1914 to 1917 ; the years when an American of German descent found himself not only defending his own American patriotism, which for a German-American was considered doubtful, but defending his ancestral German culture and heritage against a hysteria unequaled before or since in American society.

When the "Doppel Tragödie" that befell Archduke Franz Ferdinand and his wife in Sarajevo on June 28,1914 , finally reached the pages of the St. Josephs-Blatt on July 10th, the news of the assassination was preceded by a poem: "Die Trăne" by Victor Stauffer. It mirrored the Blatt's hope that war might be avoided:

Wer immer kommt zur rechten Zeit,

Der brăchte es schon ziemlich weit, Nur muß er suchen auch zu lernen, Zur rechten Zeit sich zu entfernen.

Du mußt Dich nicht gleich răchen wollen, 
Wenn der und jener Dir mißfállt;

Du kannst nicht jedem Steine grollen,

Der plump auf Deinen Weg Dir fallt. ${ }^{116}$

The Blatt began an extensive and positive coverage of the Archduke and his family, which was to continue throughout the war years. The Archduke was a part of the ever expanding Deutschtum that the German immigrant had brought to the New World. The heir to the Austrian-Hungarian throne had been a part of the GermanAmerican's heritage, and as such deserved a special place in the pages of the German language press. Appearing in many articles he became a part of the German propaganda line and subsequently a symbol of the goodness and wholesomeness of the Germanic personality and psyche.

The Blatt lauded the Archduke, whose alleged last words to his wife, Fürstin von Hohenberg, were about his children; "Sophie, bleibe am Leben für die Kinder." The loss of this "Katholik der Tat," known for his determination and opposition to the antiCatholic "Los-von-Rom" movement in Austria, was a great blow to Catholics and GermanAmericans alike. Br. Collestin used the Archduke's Catholicism to reiterate his dislike of the British and their press. Few English papers had given Franz Ferdinand positive coverage. He had been considered a bigot because of his stand against the liberal Jews in Vienna and he was described as an unpopular heir to the throne. ${ }^{117}$

Most of the early news coverage of the assassination and its consequences concentrated on the political maneuvers of the different governments involved. As early as July 17, 1914, speculations about a "plot" against Germany and Austria-Hungary, conceived by England and Russia, appeared in the Blatt. The intimate connections between these two nations were characterized as secret and anti-German. ${ }^{118}$ In the next

\footnotetext{
116 Blatt 10 July 1914: 1.

117 Blatt 17 July 1914: 1.

118 Blatt 17 July 1914: 1.
} 
issue, Br. Colestin reported that the plot was actually the combined work of the Dreiverband (England, Russia, and France) and planned in Belgrade. ${ }^{119}$ The assassination itself was considered a part of the plot and as proof, it was noted that many key political figures involved had somehow been warned of a possible assassination; King Peter of Serbia had abdicated before the assassination in order to deny any responsibility; and $\mathrm{K}$ ing Nikolaus of Montenegro returned unexpectedly to his country the day before the murders. ${ }^{120}$ The Blatt quotes a telegram that, according to a Croatian newspaper in Sarajevo, had been sent to one Major Pribitschevitsch in Belgrade. The telegram had been sent in German and read: "Beide Pferde gut verkauft!" According to the Blatt these words referred directly to the murder of the Archduke and his wife. ${ }^{121}$

The Blatt was already showing no reservations in denouncing England's part in stirring up problems in Europe. The English press's diatribes against the Archduke were dismissed as prejudiced and false. Br. Colestin accused England of two sins. One was her anti-German attitude, which he felt was obviously unwarranted, and two, her antiCatholic attitude which he felt was the cuase of her dislike for Franz Ferdinand. After all, the British were Protestant anti-Catholics and gave Franz Ferdinand no "wohlwollendes Andenken."122 On the other hand, the Archduke's unpopularity in the American press was more of a puzzle for $\mathrm{Br}$. Cölestin and basically attributed to the American press's traditional ties to the English and in more specific terms, to the Archduke's supposed hawkish determination to go to war with Russia and his unflinching opposition to Magyarism; in other words his affinity to the Prussian (read Austrian)

\footnotetext{
119 Blatt 24 July 1914: 1.

120 Blatt 7 August 1914: 1.

121 Blatt 7 August 1914: 4.

122 Blatt 17 July 1914: 1.
} 
militarism to which every German, Austrian, or Prussian was presently being connected.

Br. Cölestin believed that the characteristics for which the American press condemned the Archduke (the American press had in fact, per the Blatt, declared that the world had been done a great service by the murder of Franz Ferdinand), were exactly those characteristics that made Austria-Hungary a world power. ${ }^{128}$

In fact, according to an editorial on July 24, it had been Franz Ferdinand's strengthening of the Austrian army that had protected world peace, especially against the Russian hunger for land and domination of the slavic world. ${ }^{124}$ Germany was also praised for her efforts to keep the peace. Articles in the Blatt attributed the last 43 years of peace in Europe as a "Hauptverdienst" of Germany. ${ }^{125}$

At this point there was nothing appearing in the Blatt but praise for Germany and Austria and their handling of the situation. When Kaiser Franz Joseph of Austria issued his proclamation of war against Serbia on July 28,1914 , the Blatt reported on the Austrian celebrations which greeted the proclamation:

Diese ist fast uberall im Reiche mit großen Enthusiasmus aufgenommen wurden, da sie als eine Erlösung aus der fortwährend drohenden Lage begrüßt wurde. Es war allgemein bekannt, daß Frankreich und Rußland seit fünf Jahren bestrebt waren, Oesterreich nicht zur Ruhe kommen zu lassen und es dadurch bankerott zu machen und die gemeinen Frechheiten der Serben wurden nach und nach einfach unausstehlich. Oesterreich war es seiner Ehre schuldig, einmal durch die Tat zu zeigen, daß auch seine Gemütlichkeit ein Ende hat. ${ }^{126}$

The German people too, according to the Blatt, reacted with enthusiasm to Austria's declaration of war on Serbia, and even though England tried to call a conference of the European powers in order to settle the dispute, reports in the Blatt

123 Blatt 17 July 1914: 4.

124 Blatt 24 July 1914: 1.

125 Blatt 24 July 1914: 1.

126 Blatt 7 August 1914: 1. 
found Austria's and Germany's refusals to attend quite in order, "Selbstverståndlich hat Oesterreich auch da abgewunken und Kaiser Wilhelm war ebenfalls dagegen. ${ }^{\text {127 }}$

In the August 14, 1914 issue, there were banner headlines for the very first time: "Ganz Europa unter Waffen. Der verheerendste Krieg in der Weltgeschichte. Rußland, England, Frankreich, Belgien, Japan, Bulgarien und Serbien gegen Deutschland und Oesterreich-Ungarn."

The front page began: "In folgendem geben wir eine kurze und wahrheitsgetreue Statistik über die Entwicklung und Ereignisse dieses weltumfassenden Krieges. ${ }^{129}$ The important phrase to notice here is "wahrheitsgetreue." From this point on, the Blatt began to stress its strictest adherence to the truth, as it found it, in its coverage of the war. Like most editors of German-American newspapers in 1914, Br. Cölestin would not tire in his campaign to "truthfully" report all sides of the issues. What this meant, in fact, was a concerted effort by Br. Colestin to insure that the German side of the controversy was presented. Because so many of the German news sources in the United States had been closed even this early in the war, the majority of American newspapers were giving only the Allied version of the war news. ${ }^{130}$

The coverage of the war and its causes became the Blatt's cause celebre. This is understandable when we connect the war with the Blatt's unswerving loyalty to Germany, Austria and Detuschtum in general. It became a matter of German pride. The Blatt found itself again in the role of apologist for Germany and Austria.

\footnotetext{
127 Blatt 7 August 1914: 1.

128 Blatt 14 August 1914: 1.

129 Blatt 14 August 1914. 1.

130 Carl Frederick Wittke, German-Americans and the World War, with Special
} Emphasis on Ohio's German-language Press (columbus: n.p., 1936) 7. 
It should be pointed out her that despite the Blatt's apparent bias for Germany and Austria, in the beginning Br. Colestin felt that he was giving an unbiased account of what led up to and contributed to the war. His first step in doing so was to begin a weekly column called Vom Kriegsschauplatz. The first report was issued August 14, 1914. Described as a "kurze und wahrheitsgetreue Statistik über die Entwicklung und Ereignisse dieses weltumfassenden Krieges," the column chronologically listed dates and events in short, concise summaries of important events. The first entries read:

Der Krieg zwischen Oesterreich und Serbien. Wien, 29. Juli. Belgrad steht in Flammen. ${ }^{131}$

Oesterreich-Ungarn erklärte am 6. Aug. den Krieg mit Rußland. Die Aufregung in beiden Ländern ist eine große. ${ }^{132}$

Madrid, 6. Aug. Es heißt, daß ein britisches Geschwader bis jetzt 50 deutsche Schiffe gefangen genommen hat. (Diese Meldung scheint sehr zweifelhaft.) $)^{133}$

I have been unable to determine the sources for the Vom Kriegsschauplatz, but I believe that most information was gleaned from the dispatches issued by the British propaganda office in Wellington. The parenthetical comment following the Madrid, 6. August entry gives one the impression that the editor found the information unreliable. The information in the Kriegsschauplat $z$, which was continually published up through the end of the Blatt's coverage of the war, was basically objective and precise with an occasional comment added by Br. Cölestin. Victories and defeats of both sides were reported. All efforts on the part of both sides to find a workable peace were evenly covered. The Vom Kriegsschauplatz column is an excellent chronicle of the war.

It must be remembered that from the beginning of the war a large part of America sided with the Allies and that a majority of American newpapers:

\footnotetext{
131 Blatt 14 August 1914: 1.

132 Blatt 14 August 1914: 5.

133 Blatt 14 August 1914: 5.
} 
reflected this attitude and presented in their news columns, either purposely or because most of the news channels to Germany had been closed, what may be called the Allied version of the war....Accordingly, the German-language press felt doubly responsible for presenting the other side of the controversy. ${ }^{134}$

German-Americans were, in the beginning of the conflict in Europe, basically loyal to their homeland and to Deutschtum in general. There was no conflict yet between Anglophiles and Germanophiles. No one's loyalty to the United States had yet to be called into question. The issue of split loyalties had not yet emerged on to the American political scene. It was natural then to expect Br. Colestin to praise GermanAmerican enthusiasm for a victorious Germany. An editorial on August 14th extolling German patriotism and calling for victory for Germanentum illustrates the degree of support German-Americans and their Vereine were willing to demonstrate. The editorial is entitled "Deutsche Treue."

Im Hinblick auf die sich in Europa's Wetterwinkel drohend zusammenballenden Kriegswolken fand am Volksfestes in Brooklyn, N.Y., eine spontane und umso eindrucksvollere patriotische Demonstration statt. Ueber 10,000 Personen nahmen an dem denkwürdigen und imposanten Akte teil, bei der "Die Wacht am Rhein", "Gott erhalte, Gott beschütze unseren guten Kaiser Franz" und "Deutschland, Deutschland, über Alles" in mächtigen Akkorden durch die weiten Parkanlagen klang.

Es gab einen patriotischen Umzug, einen von Begeisterung getragenen Redeaktus und zum Schluß ward die folgende von Clemens Huenewinckell verlesene Kabeldepesche an den deutschen Kaiser gesandt:

"Begeistert von der Nachricht, daß Deutschland seinen Bundesbrudern in Oesterreich-Ungarn in der Stunde der Gefahr in echt deutscher Bundestreue zur Seite steht, entbieten die zum 31. Plattdeutschen Volksfest in Brooklyn versammelten deutsch-amerikanischen Plattdeutschen, Bayernschen Schwaben und sonstigen Vereine in Gemeinschaft mit den Vertretern der Deutschamerikanischen Nationalbundes von Brooklyn ihren Gruß und gratulieren zu dem echt deutsch-patriotischen Standpunkt mit dem Wunsche, daß die große Stunde eine glückliche Lősung finde, und daß dadurch die Suprematie des Germanentums in Europa für die Zukunft begründet sein möge im Interesse der Kultur der Menschheit." ${ }^{\text {135 }}$

During the early months of conflict the Blatt also endeavors to show that Germany and Austria and their respective monarchs were doing everything possible to prevent a 
war. Kaiser Wilhelm's annual "Nordlandreise" was described and applauded not as a vacation but as an occasion to confer with his closest advisors on how to prevent a war. ${ }^{136}$ The Blatt actually praised the deceased King Edward of England as being responsible for the current power-groupings in Europe, the Dreibund and the Dreiverband, which were given the credit for maintaining peace in Europe because of their equity in power. ${ }^{137}$ It was Germany, however, which was given the most credit for striving to keep peace. The Blatt suggested that even the governments of England, France and Russia (the Dreiverband) would not doubt the German government's love of peace. ${ }^{138}$

The Blatt also took every opportunity to point out that the Redaktion was not alone in its belief that Germany and Austria were not guilty of beginning the war:

Deutschland muß gewinnen, es führt einen gerechten Krieg. Die sămtlichen bayrischen Bischøfe haben in einem Hirtenbriefe darauf hingewiesen, Deutschland sei durch Verrat zum Kriege gezwungen worden. Die anglo-französischeamerikanische Presse, welche das Blaue vom Himmel herunterlügt, wird sich aber trotzdem nicht an die Tatsachen halten, nămlich daß Rußland, Frankreich und England die Urheber des Krieges sind. ${ }^{138}$

The issue of neutrality affected the German-American in the most number of ways. It became an issue as soon as the shots were fired in Sarajevo by the Slav extremist Gavrilo Princip. Problems and questions of neutrality appeared more and more frequently as the crisis engendered by the assassination of Archduke Ferdinand grew.

Ironically, in a nation whose constitution quarantees freedom of speech and freedom of assembly, the problem became one of constitutional rights. The United States was officially, by policy and by law, a neutral nation. As such, a German-American had the right to side with or against either of the belligerent nations. Naurally most, but

\footnotetext{
136 Blatt 24 July 1914: 1.

137 Blatt 24 July 1914: 1.

138 Blatt 24 July 1914: 1.

139 Blatt 28 August 1914: 4.
} 
not all German-Americans tended to be loyal to their homeland. Many other Americans, especially those of British descent, favored the Allies in the war.

Both powers had their proponents in the United States. Both powers had their propaganda organizations, weak and strong, operating in the country. The official policy of neutrality was announced and vigorously defended by Woodrow Wilson, President of the United States. In his neutrality proclamation, President Wilson urged neutrality in "thought" as well as in action. He understood that the United States, a nation of such a heterogenuous ethnic mix, could deal with a possible war only if all involved realized that the conflict was an internal Euorpean problem and that Americans of whatever national origin could not take sides.

On August 5, 1914, President Wilson delivered a message to the people of the United States. In it he issued a proclamation, which declared to the world that the United States was neutral and would remain neutral in the crisis. The Blatt rerported this proclamation in a one line statement as part of its Vom Kriegsschauplatz. ${ }^{140}$

In the August 14, 1914, issue of the Blatt the first editorial by Br. Coblestin on American neutrality appeared. This particular editorial was entitled in bold letters, "Neutralităt der Ver. Staaten." It read as follows:

Die Ver. Staaten werden gegenüber den europăischen Wirren, ganz gleich, welche Ausdehnung diese nehmen mőgen, eine neutrale Haltung einnehmen. Hierüber kann auch nicht der geringste Zweifel bestehn. Die Sympathien, die sich unter der Bevőlkerung je nach dem obwiegenden Elemente fühlbar machen mögen, werden an dieser Stellungnahme der Ver. Staaten nichts zu ăndern vermögen. Eine derartige Haltung ergibt sich nicht nur aus Gründen der Rechtlichkeit und Billigkeit, sondern auch allzumal aus Gründen der Notwendigkeit. Diese politik der absoluten Nichteinmischung in die Hăndel der alten Welt ist von den Tagen Washington's an maßgebend für die Ver. Staaten gewesen und ihrer getreulichen Uebung war es zu danken, daß die mancherlei Katastrophen, die im Laufe der letzten 140 Jahre über Europa hereingebrochen sind, den Vereinigten Staaten keinen sonderlichen Schaden angetan haben. Es ist of fenkündig und einleuchtend, daß ein Abirren von dieser weisen Politik, und wăre es nur in anscheinend unwesentlichen Stücken, mit unseren Traditionen, und was mindestens ebenso viel besagt, mit unseren besten Interessen im Widerspruch 
stănde, eine Mőglichkeit hierfür ist denn auch so gut wie uberhaupt nicht vorhanden. ${ }^{141}$

Thus Br. Colestin approved the official stance and established his own official policy of neutrality and that of his paper, although what he considered neutral in his reporting and editorializing quickly became an issue, eventually leading to the suspension of the publication of the St. Josephs-Blatt. Br. Colestin admits how the difficulty of remaining "unparteiisch":

Unparteiisch zu sein in diesem Volkerkriege ist eine schwierige Sache. Wir bestreben uns so viel we möglich allen Nationen gerecht zu werden und besonderes keine irgendwie zu verletzen. Aber auch wir können es nicht allen recht machen. Das Blut kocht in den Adern, wenn wir sehen, wie sozusagen die ganze Welt sich gegen die deutschen Nationen verschworen hat, wie ein allgemeiner und planmäßiger Verleumdungsfeldzug gegen sie geführt wird... ${ }^{142}$

And he was not alone in his battle to keep America neutral. Up until April 6, 1917, when the United States entered the war, a majority of German-American newspapers were adamant in their call for American neutrality. ${ }^{143}$

In the meantime the Blatt continued to show that Britain was not the hero in this war. The Blatt's coverage of the British begins very quickly to show a certain prejudice and in doing so Br. Cölestin did not hesitate to use the British against themselves. On August 21, 1914, the Blatt takes up a propaganda ploy that both sides eventually used but one that the Germans used more extensively in their campaign: quoting a citizen of a neutral country or an enemy country speaking out for the German cause. In one such incident the Blatt quoted Sir Roger Casement, a former British diplomat:

Ich beklage diesen unseligen Krieg, er ist ein Verbrechen wider der Menschheit; aber ich glaube nicht, daß Deutschland der schuldige Teil ist. Deutschland hat den Kampf nicht gewollt, sondern muß für seine Existenz Krieg führen. Es kămpft für die europăische Zivilization. Deutschland...vertritt nach meiner Meinung die Tüchtigkeit, die Kultur und die Mannestugenden der weißen Rasse

\footnotetext{
141 Blatt 2 October 1914: 1.

142 Blatt 2 October 1914: 1.

143 Rippley 164.
} 
vom kontinentalen Europa. Aus diesem Grunde gehơren meine Sympathien den Deutschen....Als ich die Stelle aus der Rede des deutschen Kanzlers "Laßt eure Herzen zu Gott schlagen und eure Făuste auf die Feinden las, ward es mir klar, $\mathrm{daB}$ das deutsche Volk ein Recht hat, auf seinen Kaiser und sein Land stolz zu sein. ${ }^{144}$

In a different version of the same type of propaganda ploy, the Blatt quoted George Bernard Shaw in its denunciation of Britain. In a story for an American paper Shaw told the world how "gentlemen" like the British had executed a 60 year old man who had been accused of mistreating an English hunting party, which had allegedly shot pigeons illegally. The Blatt spells out the punishment meted out to the sexagenarian: removed from his home by force, he was executed in front of his family, neighbors, and friends. ${ }^{145}$

Another instance of quoting neutrals or enemies who agree with the German position is used here. "A Frenchman as witness to the peace-loving Kaiser Wilhelm." The French psychologist Lebon published a study of the German Emperor, which was not well-received in France. Lebon declares the Kaiser innocent of starting the war and praises him as peace loving. It was the early dates of the mobilization that led eventually to war -- they went so fast they could not be controlled. According to $\mathrm{Br}$. Cölestin these sentences are the most objective written since the outbreak of war. ${ }^{146}$ By August, 1914, the issue of contraband was being discussed in Washington and reported by newspapers. The contraband being discussed were items being shipped from the United States to countries involved in the European conflict. The American government wanted to be certain that its official neutrality be maintained at all cost. Trade with the belligerents could be construed as unneutral. In the Blatt the administration was lauded for its attempt to maintain American neutrality, although the

144 Blatt 21 August 1914: 4.

145 Blatt 16 October 1914: 4.

146 Blatt 3 March 1916: 7. 
paper found fault with some of the measures. First of all, an of ficial list of contraband had yet to be published. Secondly, the commander of the forces responsible for patrolling the Atlantic coast and overseeing the campaign, Commander Sims, was reportedly the same Commander Sims who had previously given an anti-German speech in London and who had received a rather mild rebuke from the American government. ${ }^{147}$ The government, commented the Blatt, despite all assurances to the contrary, was not yet as neutral as it should be. The issue of contraband, especially what constituted contraband, and with whom the Wilson Administration finally allowed American manufacturers to trade, would become more and more devisive as the war continued.

By August of 1914 the Germans had already begun their march through Belgium. Lütich was in the hands of the German forces and the remaining forts in Belgium that had any kind of strong fortifications were being destroyed. Brussels had fallen to the Germans by August 28th. ${ }^{148}$ The newest controversy Germany faced was her violation of Belgium's neutrality. The overwhelming sentiment was against Germany.

Germany's march through neutral Belgium was covered by Br. Collestin one month after the actual invasion. Although it had not been mentioned in the Blatt up to this point, the story must have appeared in the socalled "Anglo-American" press. In the September 4, 1914, issue, as part of the Rundschau the Blatt defends Germany's decision to use Belgium as a bridge to France. In doing so Br. Cölestin parrots the official German explanation:

Belgien, welches nun von den Deutschen beherrscht wird, steht in Gefahr von der Karte zu verschwinden. Ganz ohne Schuld sind der König und die Regierung nicht. Deutschland hat sich Belgien gegenüber in ernster $\mathrm{K}$ risis sehr nobel gezeigt. Vor dem Einmarsch seiner Truppen garantierte der deutsche Kaiser, daß der Besitz Belgiens nicht angetastet und das Land wieder gerăumt werden würde, sobald die Kriegsereignisse es gestatten, aber Kaiser Wilhelm erhielt eine schroffe Abweisung. Nach dem Fall von Lüttich ist der Kaiser neuerdings mit einem 
friedlichen Anerbieten an die Belgier herangetreten, um abermals abgewiesen zu werden. England und Frankreich gegenüber aber hat es Belgien mit der Neutralităt nicht so ernst genommen, sondern hat ein geheimes Abkommen mit jenen Lăndern getroffen, es hat seine Festungen von den Franzosen modernisieren lassen und hat gestattet, daß franzosische Truppen vor der Kriegserklărung zur Verstărkung der Garnisonen in Lüttich, Namur, etc. die Grenze überschritten haben. Die Freundschaft mit den hinterlistigen Nachbarn wird Belgien jetzt bitter büßen müssen. Es war zudem absolut verwerflich, daß Belgien sich anmaßte, dem măchtigen Deutschland, das ohnehin den Bestand Belgien garantierte und als Freund kam, zu trotzen und 16,000 Mann auf dem Schlachtfeld verbluten zu lassen, sowie etwa 50,000 teilweise lebenslănglich zu Krüppeln schießen zu lassen. So groß nămlich sollen die Opfer Belgiens sein. Da waren Kơnig Albert und seine Regierung ubel beraten und sie können sich jetzt bei ihren "Freunden" bedanken. ${ }^{149}$

The Blatt reports the official German propaganda line: It was not Germany who violated Belgium's neutrality, but the Allies who, by making treaties with neutral countries, invalidated these countries' neutrality. Belgium was then responsible for her own predicament because of secret agreements with France and Britain that allowed France to modernize Belgium's fortresses and allow French troops to cross the border to man the garrisons in Lüttich, Namur, and others. ${ }^{150}$

Part of the German propaganda that was developed to counter the British exploitation of Germany's invasion of Belgium was the publishing of papers allegedly proving that Belgium had held these secret meetings with France and Britain resulting in the agreements mentioned above. ${ }^{151}$

The Blatt continued to repeat the same claims as long as the Belgium story was news. Weapons made in France and allegedly confiscated by the Germans in Belgium were grounds for Br. Cölestin to believe Belgium had agreed as early as February of 1914 to fight alongside France. ${ }^{152} \mathrm{Br}$. Cölestin finally dismissed the problem of Belgium's loss

149 Blatt 4 SEptember 1914: 1.

150 Blatt 4 September 1914: 1.

151 Harold D. Lasswell, Propaganda Technique in the World War (London: Kegan, Trench, Trubner \& Co., Ltd., 1927) 65.

152 Blatt 20 November 1914: 3. 
of national integrity in an editorial as "sad" but inevitable since she had "dug her own grave. ${ }^{n 153}$

When Japan entered the war on the side of the Allies, the Blatt reminded its readers that one of Japan's motives for entering the war against Germany was to regain the colony of Kiautschou on the Chinese mainland. The colony, a rich and promising prize, was created and maintained by German "Fleiß, Tüchtigkeit und Kapital," but most important, argued the Blatt, was that China was neutral and Japan could not take Kiautschou without compromising China's neutrality.

Da drücken aber alle Feinde Deutschlands, die so sehr gegen die Verletzung der belgischen Neutralităt durch die Deutschen gewettert haben, hübsch die Augen zu. Sogar die Ver. Staaten schweigen und schauen zu, wie ihre verhaßten Gegner sich unmittelbar vor ihrer Rasse festsetzen. Ja in Washington, ist man so naiv zu glauben, Japan werde Kiautschow [sic] den Chinese zurückgeben. Dieses Verhalten unserer Regierung in dem Streit um Kiautschou wird sich noch einmal bitter rächen. ${ }^{154}$

The Blatt also takes Britain to task for allying itself with Japan, a "barbaric" country in order to destroy Germany:

...von allen Streichen des perfiden Albion ist dies vielleicht der schmutzigste und gemeinste. --Wie es die englischen Staatsmănner vor der Welt verantworten konnen, einem stammverwandten, kulturell hoch entwickelten Volke, das in schwerem Kampfe um seine Existenz ringt, noch diese asiastischen Barbaren mit den nur schwach maskierten Raubtierinstinkten auf den Hals zu hetzen, ist eine Sache, die sie mit sich selbst abmachen müssen. Diese Tat spricht allen Gesetzen der Natur und allen Regeln eines ehrlichen Kampfes Hohn. Die unbestechliche und unwandelbare Gerechtigkeit der Weltgeschichte wird diese Tat einst furchtbar an den britischen Staatsmănnern und dem britischen Volke răchen. ${ }^{155}$

Kiautschou becomes more than just an issue of neutral rights; it becomes an issue of culture versus barbarism. The Japanese issued an ultimatum demanding that Germany leave the Chinese colony it had settled. The Blatt takes a stand against the move 
believing that it would cause great hardship not only on Germany but on the Chinese. Germany is praised highly for its "Kulturarbeit" in Kiautschou. The quality of the colony was a direct result of the good work done by the German government, German businessmen, and German school teachers.

The Blatt insists that Germany is required to ignore the ultimatum from Japan, not out of desire for prestige or economic interests, but in consideration of cultural progress. Germany, if it fights in Kiautschou, will be fighting for the enlightenment of the human spirit. For the first time Br. Colestin describes the war, especially now that Japan has entered the fighting, as a "Kampf für Kultur und gegen Barbarei." The Japanese are described as the "gelbe Scharen" and the peoples of French African colonies are called the "schwarze Horden." The Blatt warns the American people that President Woodrow Wilson and Secretary of State Bryan are naive if they believe that Japan will return Kiautschou to China. ${ }^{156}$

In addition to defending Germany in open editorials on the war issue, the Blatt also undertook to raise the image of Germany in more indirect ways. Very soon after the war broke out the St. Josephs-Blatt began a concerted effort to show Germany and German culture and traditions in a positive light. This effort resulted in a number of purely romantic articles on a number of different topics, for example, German prisoners in the United States requested parole in order to return home to fight for their fatherland. $\mathbf{1 5 7}$

One especially descriptive article appeared in August of 1914 titled "Mit Gott für Kaiser und Reich." The article is a short, romantic history of the Iron Cross. Emperor Wilhelm is praised by the Blatt for re-issuing the medal. By doing so, he has followed the example of his grandfather, Emperor Wilhelm I, when he re-issued the Iron Cross as 
a decoration for valor and courage during the German-French War of 1870 and 1871 . The Blatt describes the creation of the medal by King Friedrich Wilhelm III of Prussia on March 10,1813, in Breslau as an order for service to the Fatherland in the War of Liberation against France. The different ranks of the order are mentioned as well as the associated ribbons. The foundation created by Friedrich Wilhelm IV in 1841 for the recipients of the decoration is also described.

It is this type of story that the Blatt has begun to use as part of its campaign to prove to the West Coast that Germany is honorable and peace loving. The Blatt is now taking every opportunity to celebrate its Deutschtum. For example, Kaiser Franz Joseph's 84th birthday is used as an occasion to praise him for his valor and bravery in leading his countrymen into battle against the "serbische Mordbuben." ${ }^{158}$ Another story, obviously designed to tug at the heartstrings of the readers of the Blatt, was on the children of the assassinated Archduke, how they played, how they were being raised, and what good, brave altar-boys they were..$^{159}$

As part of this particular propaganda campaign the Blatt published an interesting letter about the differences between the royal families of Germany and England. This letter, by a certain "Karl Müller, contrasts the great, brave Kaiser, who goes to the front with his men, and King George of England, the "Pantoffelheld." The Kaiser is described as a man of war, at the front with his men. The King, on the other hand, is described as a homebody, sitting before a fire with the Queen. The German princes are lauded for giving their lives to the Fatherland, but the Prince of Wales is taunted for staying out of the fighting because of an appendicitus. A typical English excuse, writes Br. Colestin. It was nothing more than fear that gave him his stomach aches. Hoefully the Frau Mama will let him smoke cigarettes so that he will have another excuse if 
something should happen! And the brave English heros, where are they? Their mothers and daugthers are ashamed of them and are trying to take up arms. To earn a shilling seems more important to them than to save their Fatherland. ${ }^{160}$

By August 28, a month after Austria declared war on Serbia and less than a month after Germany declared war on Russia the Blatt enthusiastically predicted Austria's and Germany's imminent victory over the combined forces of her enemies. In an editorial, the Blatt's unbridled enthusiasm for the victory is boldly expressed:

Vor hundert Jahren trat Frankreich unter Napoleon I. Deutschland, Österreich, Italien, Rußland und England entgegen -- und war siegreich. Wir erwarten, daß Deutschland und Österreich, gegen welche sich sozusagen das ganze Europa erhoben hat, um sie am Boden zu zerschmettern, siegreich aus dem schweren und ungleichen Kampfe hervorgehen werden. Sie haben es redlich und ehrlich verdient. ${ }^{161}$

This confidence in the Central Powers' ability to win the war is held not only by the editor of the Blatt but by many of the paper's German-American readers. In a weekly "letters to the editor" feature called Briefkasten, subscribers frequently wrote in expressing one sentiment or another. The Blatt did not reprint the original letters but following the initials of the writer and place of origin, the Redaktion answered the questions or replied to the comments of the sender; the answers give the clues as to what was being asked. It was not unusual to see answers to letters that had come from as far away as San Francisco.

In one such letter the editor of the Blatt reiterated his firm belief "in the victory of German weapons in the dreadful world war." In the reply Emperor Wilhelm is given the new honorific of "Friedenskaiser" to be worn along with that of "Heldenkaiser." Responding to this reader's request, the Blatt reprinted three stanzas of "Deutschland, 
Deutschland, über Alles" while ascribing envy of Germany's "wonderful blossoming" as one of her enemies reasons for forcing the Emperor into a war. ${ }^{162}$

J.G., San Francisco. Wir glauben fest an den Sieg der deutschen Waffen in dem entsetzlichen Weltkrieg; Kaiser Wilhelm wird dann neben dem Ehrentitel "Friedenskaiser" auch den Ruhmestitel "Heldenkaiser" füren. Die Feinde Deutschlands, gelb geworden vor Neid ob des geradezu wunderbaren Aufblühens Deutschlands, haben Kaiser Wilhelm das Schwert in die Hand gedrückt. Um Ihrem Wunsche und wahrscheinlich auch dem Wunsche der Mehrzahl unserer Leser zu entsprechen, bringen wir das betreffende Lied hier zum Abdruck:

Deutschland, Deutschland über alles, Ueber alles in der Welt, Wenn es stets zu Schutz und Trutze Brüderlich zusammenhălt! Von der Maas bis an die Memel, Von der Etsch bis an den Belt -Deutschland, Deutschland über alles, Ueber alles in der Welt! ${ }^{163}$

This faith in the Central Powers' victory over the rest of Europe is nourished by the Blatt and by most other German-American newspapers until 1917 when the United States entered the war. ${ }^{164}$ In the meantime, the September 4, 1914, Rundschau headlined with "Hurra! Auf nach Paris!!" celebrates the vindication of the Blatt's claims that the French and British reports of victories in Europe had been lies. The Blatt quotes Mirza Schaffy as saying, "Wer da lügt, muß Prügel haben." And "Prügel" is just exactly what the Blatt claims France and England have received. so much, in fact, that their harbors are no longer whole. The report offers the good news:

Der erste Teil der gewaltigen Schlacht zw. den Deutschen und den Alliierten (Franzosen, Englănder und Belgier) ist ausgefochten worden und endete mit eineim glănzende Siege der Deutschen. Der franzősische Ehrgeiz hat eine tiefe Wunde erhalten und die vielgerühmte franzősische Strategie hat versagt. Das franz. Kriegsbulletin sagt ganz lakonisch: "Infolge unvorhergesehener Schwierigkeiten sind wir zum Rückzug in geschützte Positionen gezwungen gewesen." Die Franzosen gestehen also, daß sie nicht imstande gewesen sind, das Vordringen der Deutschen auf zuhalten. "Geschützte Positionen" meint hier nichts

162 Blatt 4 September 1914: 3.

163 Blatt 4 September 1914: 3.

164 Wittke 166. 
anderes als die Festungen entlang der Heerstraße nach dem Herzen Frankreichs. Der Sieg gibt Deutschland freie Bewegung in Belgien und hat die Hoffnung Frankreichs und seiner Verbundeten vernichtet, die Deutschen an der Grenze aufs Haupt zu schlagen und sie müssen nun ihre ganze Energie dem bedrohten Paris zuwenden. Die năchsten Schlachten werden auf französischem Boden geschlagen.... ${ }^{165}$

The article continues with an expansive description of the successes of the Germans in this particular battle and ends with:

Der erste große Sieg der Deutschen muß eine große moralische Wirkung ausüben, so daß Italien, Rumanien und Bulgarien, die zum Losschlagen bereit sind, sich zweimal besinnen werden, ehe sie gegen Deutschland und Österreich-Ungarn ins Feld ziehen. ${ }^{166}$

In the July 2, 1915, issue the Blatt again restates its belief that Germany will win the war. According to the Blatt: Germany and Austria have won, and will win. We have not deceived ourselves. On the contrary, our expectations have been exceeded. Not since the beginning of this murderous war has the situation for the Central Powers been so shining. 167

Part of the problem that $\mathrm{Br}$. Colestin found while trying to report a "wahreheitsgetreue" version of the war news was the abundant amount of anti-German reporting found in what he referred to as the "Anglo-American" press. Not only did he feel that this coverage was highly biased in favor of England and the Allies, but most blatant of all, that much of it, according to the Blatt, was out and out lies. Br. Cölestin began to answer and counter what he saw as the animosity of the "Anglo-American" press coverage of the war news. He was also determined to help the public recognize the blatant lies that were being foisted onto the American people through the "englische Lügenpresse":

\footnotetext{
165 Blatt 4 September 1914: 1.

166 Blatt 4 September 1914: 1.

167 Blatt 2 July 1915: 1.
} 
Die Deutschen kőnnen nicht schießen, ihre Artillerie taugt nichts, die Geschosse ihrer Geschütze richten keinen Schaden an, ihre Kavallerie kann nicht reiten, derartige Mitteilungen kann man jeden Tag in allen Variationen in der hiesigen englisch/amerikanischen Presse lesen. Ob sich das Publikum diesen haarstrăubenden Blodsinn noch lange wird ruhig gefallen lassen und dafür bezahlen wird? ${ }^{168}$

Throughout the coverage of the war news -- from the beginning in 1914 to the entry of America into the war -- the Blatt reported on what it called the complicity of the "Anglo-American, pro-British' press in the Allied conspiracy to force the United States into war against Germany. The "blatant lies" being imposed upon the American public through the "englische Lügenpresse" were being repeated by the American press, which the Blatt was determined to counter.

Since the cable to the United States had been cut by Britain early in the war, most if not all of the news being printed in the United States came from sources which Britain controlled very carefully. Censorship of the press in England, allowed under the Defense of the Realm Act (DORA), which gave control over "all statements intended or likely to prejudice His Majesty's relations with foreign powers," was one of Britain's most effective propaganda moves. ${ }^{169}$ The American press was forced to get its news where it could and that was from England. Even news from other European countries was "filtered through the British censorship" and this in effect meant that "British news...became American news. ${ }^{170}$ And even though there were many American news correspondents on the battlefields in Europe, all trying to get un-biased news home to America, the British censors had too much control over what was sent out to allow for an objective analysis. ${ }^{171}$

168 Blatt 28 August 1914: 4.

169 H.C. Peterson, Propaganda for War: The Campaign against American Neutrality, 1914-1917 (Port Washington: Kennikat Press, Inc., 1939) 12.

170 Peterson 14.

171 Peterson 14. 
The British control over the war news became so obvious that the Blatt noted numerous times that the dispatches received about the war contained a lot of misinformation. Br. Cőlestin subsequently assured his readers that he would give them a very careful "Auslesen from the dispatches in order to get to the truth. ${ }^{172}$

Br. Cölestin wrote a vitriolic Rundschau on October 9, 1914, taking the American press and public to task. It gives a great deal of insight into just how the Blatt received its information. Beginning with a complaint about the numerous "Lügenblatter," that he has to read, he calls them "Quatsch." He is thankful that the readers of the Blatt do not have to read this "Lektüre von Lügen und Schauergeschichten," which he is forced to read because the Blatt receives no cable or radio signals:

Es ist gegenwärtig so viel von Neutralităt die Rede, wenigstens wenn es sich um Deutschland und Oesterreich handelt. [Unreadable word] Neutralităt, wie sie hier von der Großzahl der Amerikaner und ihrer Presse verstanden wird, hat aber ein Loch.

Man könnte bald meinen, die Ver. Staaten seien eine englische Kolonie. Gleich am Anfang des Krieges würde von englischer Seite das deutsche Kabel durchschnitten, wodurch das schon durch Waffengewalt schwer bedrăngte Deutschland auch in idealer Hinsicht schwer geschădigt wurde. Die amerikanische Regierung rührte keine Hand. Im Gegenteil. Sogar die drahtlose Telegraphie Deutschlands wurde verboten, und erst, nachdem die englische Presse die amerikanische Publikum durch Lügen vergiftet hatte, gelang es der deutschen Regierung, wenigstens amtliche Depeschen durch Funkenspruch zu übermitteln; aber selbst diese wurden der amerikanischen Zenzur unterworfen. Und wie steht es mit der Zenzur der englischen Nachrichten? Wir haben nichts davon gehört. Es ist vielmehr der amerikanisch-englischen Presse gestattet, die schamlosesten Lügen und Verletzungen Deutschland gegenüber zu veröffentlichen und die amerikanische Regierung tut auch nichts dagegen, wenn in den eigenen Landeszeitungen englische Redakteure sitzen und durch Wort und Bild Deutschland und Oesterreich-Ungarn, und somit einen großen Teil amerikanischer Bürger und Einwohner beschmutzen. Unsere Regierung sagt kein Wort, wenn England die Fracht neutraler Schiffe in neutralen Gewässern (Holland) kapert, angeblich weil sie für Deutschland bestimmt sei, wăhrend dieselbe England und auch Frankreich Lebensmittel jeder Art, Waffen, Flugsmachinen, Pferde usw., aus den Ver. Staaten exportiert.

Noch etwas. Als es ein paar Tage lang mit den Aussichten der Deutschen im Kriege schlecht zu stehen schien, beeilte sich bekanntlich Prăsident Wilson in seiner Herzensgüte an den Kaiser zu telegraphieren, ob derselbe nicht bereit sei, über den Frieden zu verhandeln. Was wir über diese Depesche gedacht haben und noch denken, haben wir unseren Lesern nicht vorenthalten, und die Antwort, 
welche der deutsche Reichskanzler dem Prăsidenten herübergekabelt hat, war höchst sachgemåß und wirkte erf rischend. Wer zwischen den Zeilen zu lesen verstand, ersah daraus, daß der Reichskanzler meinte: "Wenn die Herren Alliierten Frieden haben wollen, so sollen sie uns kommen -- wir haben "kein BusineB", ihnen entgegenzukommen. Und noch deutlicher war, was der deutscher Boschafter Graf Bernstorff in dieser Sache in New York gesprochen hat.

Das der Prăs. in der Sache an den Kaiser telegraphierte, und diesem von Neuem seine schon einmal mit Dank quittierte und zurückgewiesene Vermittlungsofferte wiederholte, wăhrend es ihm gar nicht einfiel, den Alliierten ebenfalls eine solche Offerte aufzuoctrovieren (unreadable), warf sicher ein hőchst eigentümliches Licht auf die Neutralităt, welche Prăs. Wilson vorher erklărt hatte. Denn welcher Art dieser Frieden gewesen sein würde, lag ja auf der Hand, es konnte absolut kein anderer sein als ein "Peace made in England". Seitdem aber hat sich das Blăttchen gewendet, und nun kehrte Herr Wilson ganz wieder zur alten Neutralităt zurück und erklărt, er kőnne die Alliierten nicht auffordern, Frieden zu schließen, ohne die Ver. Staaten dadurch vielleicht zu kompromittieren oder in Komplikationen zu verwickeln. Also jetzt, wo die Aktien Deutschland wieder gestiegen sind, wird nicht mehr von Friedensvermittlung gesprochen, jetzt will der Prăsident ruhig abwarten, bis die Ereignisse selber zur Frieden drăngen. Das ist sehr vernünftig von Herrn Wilson und es wăre vielleicht besser gewesen, wenn er von vornherein diese Politik befolgt hătte. ${ }^{173}$

The Blatt's coverage of the war news through the Vom Kriegsschauplatz continues in the August 28, 1914, issue. In it much of the information is now followed by editorial comments. A report titled "Faustdicke Lügen" telling of numerous victories by the Belgians over Germans is followed by: "Merkwürdig, wie viele Siege die Belgier über die Deutschen schon errungen haben, die trotz ihrer 'Siege' sich immer rückwărts bewegen und sogar den Sitz der Regierung von Brussel nach Antwerpen verlegt haben."174 In the same Vom Kriegsschauplatz a report titled "Die deutsche Armee dringt unaufhaltsam vor" is printed without any particular comments:

Die Deutschen treiben die Belgier auf der ganzen Linie zurück. Die deut. Kavallerie ist bis nördlich von Antwerpen vorgedrungen. Die Einnahme von Brussels [sic] gilt als gewiß. Die Konnigin, sowie såmtliche Mitglieder der franz. und russischen Gesandtschaft sind nach Antwerpen geflohen. König Albert bleibt im Feld bei den Truppen. ${ }^{175}$ 
In an article commemorating the anniversary of America's "Erbfeind" England burning the Capitol in Washington in 1814 the Blatt used another German progaganda ploy to remind its readers about the historical animosity between the United States and Great Britain. ${ }^{178}$ This was just the first shot of a long anti-British propaganda barrage perpetrated by the German language press, reminding Americans of every major and minor incident attributed to the British during the Revolutionary War and the War of 1812. 177 In May and June of 1915 , as part of this propagand campaign, "Lest We Forget," a poem first published in Harper's Weekly on May 18, 1863, was reprinted throughout the United States. ${ }^{178}$ The Blatt published the poem in full on June 25, 1915. In an article called, "Is England a friend of the United States?" the editor of the Blatt answers with the statement: "Anyone who reads [Lest We Forget] must answer no to the above question." The poem is as follows:

We will remember it -- England's "neutrality", We who have witnessed her cowardly craft; Friendly in seeming, a foe in reality, Wiping her eyes, while she inwardly laughed.

We will remember when round us were lying Thousands of gallant men, wounded and dead. Rebels on all sides our pathway defying -"Down with our rival" was all England said.

We will remember her sham aristocracy, Cheerful and jubilant over our fall, Helping when treason would stifle democracy, Turning a deaf ear to liberty's call.

We will remember with lasting emotion, When her starved workmen were grasping for breath.

While stores of grain WE sent over the ocean, Her ships came laden with weapons of death.

We will remember the Keokuk sinking,

176 Blatt 4 September 1914: 4.

177 Lasswell 128.

178 Wittke 182. 
Riddled with balls "neutral England" had sent;

We will remember her laughing and winking,

Feasting arch-traitors on board of the Trent.

We will remember it when we are stronger.

When once again we stand saved and erect;

Her neutral mask shall shield England no-longer,

By their foul deeds she'll know what to expect! ${ }^{179}$

At the end of the article the paper also reminds the reader. "Wăre es nicht für die heute verdăchtigten sagen, 'Bindestrich Amerikaner' gewesen, so wăre die Union der britischen Tücke unterlegen." $^{\text {180 }}$ In Br. Colestin's opinion, this poem seemed quite appropriate for 1915. English treachery and aristocraticness, which were naturally distrusted by the greater part of the American populace, were noted as attributes that separated America from England. The poem evokes memories of English treachery and strongly rebukes those who might forget.

In a poem by J. Rothensteiner called "England," British greed, hunger for land, and willingness to fight are negative points in a very negative poem:

Ich bin die Herrscherin der Welt,

Mein Reich so weit, als reicht mein Geld.

Und meine Boten, Ost und West,

Sind Krieg und Hungernot und Pest.

Die Klugheit ist mein Diadem:

Das Kămpfen mach ich mir bequem.

Ich hetze Volk und Volker auf,

Dabei hab ich gar leichten Kauf.

Ein Söldnerhausen ist mein Heer, Und Söldner peitschen mir die Meer.

Ich selbst verachte sie darum,

Weshalb ist auch die Welt so dumm?

Der Hunger ist mein Herrscherstab, Ich nehme, was die Erde gab.

Ich lass den Schwachen nur die Wahl: Gehorsam oder Todesqual.

Blatt 25 June 1915: 7. 


\begin{abstract}
Alt Irland weiß, wie schrecklich hart Ihm Mut und Kraft gebrochen ward, Am Hungertuch der Inder nagt, Sobald er sich $z u$ regen wagt. Und Deutschland selbst und Oesterreich Sie werden wohl von Hunger bleich. Und stehn sie mir zu lange fest Dann kommt am Ende noch die Pest.

Und sinkt der Freund, und sinkt der Feind

Mir bleibt es gleich, wer klagt und weint:

Wie oft ward Freund in Feind verkehrt!

Von Toten mir sich keiner wehrt.

Ich bin die Herscherin der Welt, Mein Reich so weit, als reicht mein Geld. Und meine Boten, Ost und West, Sind Krieg und Hungernot und Pest. ${ }^{181}$
\end{abstract}

All the while that Br. Cölestin was trying to maintain his neutral press coverage of the war in Europe, many considered the Blatt one of their only resources to read the German side of the story. Others considered the stories and news in the Blatt as distorted and biased against the Allies. Br. Cölestin did not hide the fact that some disagreed with his editorial policies. In fact, he let his readership know by publishing many of the anti-St. Josephs-Blatt letters to the editor that he received. To his chagrin, one of the first letters he received was from the Trappist monks at the Abbey of Gethsemani in Oregon requesting that the St. Josephs-Blatt no longer be sent to the Abbey. Br. Cölestin printed the letter in the September 11, 1914, issue. The Trappists found it surprising that a Catholic paper like the Blatt would print so much "German war news." They suggested that the Blatt should be like the English Catholic papers and only pray for peace. Br. Colestin answered that the Blatt never lost sight of its goal of honoring St. Joseph, but it was duty bound to reserve space for war news, which was the most important news in $1914 .^{182}$ 
Many other letters of such ilk were received. Not all were as polite as the one from Gethsemani. One letter from Canada began with "You french eating Prussians!" The Blatt comments that this reader probably had a German name (the letter was sent unsigned), but living in Canada he probably also hated all things German, because of the historical Canadian animosity for the Kaiser. ${ }^{183}$

The influx of letters addressed to the editor of the Blatt reached a point that Br. Cölestin created a new letter section called $Z$ wischen Uns. The first installment on October 9, 1914, was correspondence from some of the Blatt's readers who disagreed with the paper's "neutrales Verhalten" towards Germany. The editor called all of this the Blatt's "Kleinkrieg." What seemed to anger his readers was the paper's criticism of the French-English press and their animosity towards Germany and the Kaiser. "Wir protestieren, wenn in englischem Solde stehende amerikanische Blätter von Deutschen Horden sprechen und bemerken, daß wir Amerikaner die allergeringste Ursache haben, Deutschland anzuschwärzen." The Blatt then reprints a number of letters in English. Two examples:

Guthrie, Gentlemen: --I have not ordered the "St. Josephs-blatt" and I want you to discontinue sending it. I prefer the "Menace" to your sheet....There is no room on American soil for your German fanaticism....Yours truly, (Rev.) Charles Standaerd.

Silver City, N.M., ...Send your stuff to the real slaves of the Kaiser. H. Heiz. ${ }^{184}$

The December 4, 1914, Rundschau begins with a another report that many of the Blatt's readers felt that the Blatt should not report about the war. Br. Cölestin answers that the war is the most important cultural-historic event of the century, which must be "gebührend registriert werden," and that it cannot be denied by any intelligent man, that he reports it to the best of his knowledge and conscience. The fact that the Blatt's

Blatt 11 September 1914: 4.

184 Charles Standaerd, letter; H. Heiz, letter, St. Josephs-Blalt 9 October 1914: 3. 
sympathies are with the side of Germany and Austria-Hungary will be understood by the friends of the French and the English if they "sich an der Hand von Beweisen überzeugt haben, daß weder Deutschland noch Österreich die Fackel ins Pulverfaß geworfen habe, welche den Weltbrand entfachte. ${ }^{\text {185 }}$

The June 18, 1915, issue presents the next Zwischen Uns column. Another anti-St. Josephs-Blatt letter was received complaing about the Blatt's position calling for a "Waffenausfuhrverbot." The letter called the Blatt anti-American. Br. Collestin answers:

Wir sind dieser Tage in den Besitz eines Briefes gelangt, in welchem wir nicht nur unsere Stellungsnahme im gegenwărtigen Weltkriege getadelt wird, sondern auch als Feind der Ver. Staaten angeklagt werden....Bezüglich unserer Richtung in dem Völkerkriege und ganz besonders in der Agitation für ein Waffenausfuhrverbot stehen Millionen von Amerikanern auf unserer Seite. Die Bundesregierung ist in vielen Millionen von Unterschriften aus allen Klassen der Bevölkerung wiederholt und dringend ersucht worden, ein solches Ausfuhrverbot zu erlassen, indem sie nicht nur auf die schwere Verantwortung, welche unser Land dadurch auf sich nimmt, hinweisen, sondern sie haben sich auch für eine ehrliche Neutralität erklărt. Was aber Millionen von Amerikanern tun, das wird auch dem Redakteur des St. Josephs Blattes gestattet sein. Und wenn unsere Sympathie auf Seite der gerechten Sache der Deutschen und Oesterreicher ist, so hat niemand ein Recht uns darob zu tadeln. Als Amerikaner haben wir unter der Verfassung des States [sic] und des Bundes das Recht, unsere Sympathie zu bezeugen, solange wir innerhalb der Gesetze handeln. ${ }^{186}$

The editor answers a particularly bad letter in Briefkasten. Br. Collestin informs the letter writer L.M., that the Blatt will not stop telling the truth because of threats. He is surprised that the writer believes that the starvation plan of England against millions of innocent children and women is a "durchaus rechtmăssige und erlaubte Kriegsmaßregel." ${ }^{\text {187 }}$

This letter praises a central topic in the war of words which raged between 1914 and 1917, that of "atrocities." Accusations of war atrocities became so profuse in the quest to secure America as an ally, that from one week to another it became increasingly

Blatt 4 December 1914: 1. 
difficult to distinguish who was doing what to whom. Once one side accused the other of a particular crime, the accused immediately countered with accusations of his own. It became a matter of degree as to who had committed the most dastardly of crimes.

The British, however, appeared to have won the upper hand in this battle of riposte and retort. As usual, their propaganda machine exploited all possible opportunities which presented them with any evidence of German wrong doing. The Germans, on the other hand, ignored, misread or misjudged many opportunities to take the offensive. Instead, most of the stories circulated in the American and GermanAmerican press of British crimes were defensive countercharges. ${ }^{188}$

Most German-American newspapers regularly filled columns with denials of the stories being printed about the Germans by the American press. ${ }^{189}$ The St. Josephs-Blatt countered these stories by regularly accusing the British of atrocities, defending German actions which had been condemned as crimes, and reporting stories describing the humanity of the Germans.

Because of a lack of military atrocities that could be attributed to the British -- a result of both the thoroughness of the British censors and the lack of aggressive propaganda by the Germans in the United States (they believed that Americans could be won over by the "truth about the war" or "actualities of the case" ${ }^{\text {190 }}$ ) - - the Blatt published stories of innocent Germans who, living in British and Canadian cities, were persecuted, mistreated and killed. Their shops were plundered and destroyed, and because their lives could no longer be assured, they were subsequently taken to "concentration camps." The British government, according to the Blatt, pretended to be

Peterson 140.

189

Luebke 93.

190

Peterson 142. 
helpless in the face of such mass hysteria. ${ }^{191}$ Yet, the Blatt continues, the British government had just given Viscount Byrne permission to publish a book on the atrocities of the Germans against Belgium and France. ${ }^{192}$ The Blatt calls that "infame Heuchelei," since no nation had more to be ashamed of than England, which had hunted hundreds of thousands to death through their "Ausbeutungssystem." 193

The Blatt dedicated many articles and editorials in repudiating the atrocities allegedly committed by Germany and the Axis Powers against the Belgians. Immediately following Germany's violation of Belgium's neutrality, the American press filled its papers with stories of German barbarism and inhumanity. The German-American press countered immediately, but found itself fighting an uphill battle. These detailed stories of alleged German atrocities proved the most difficult to rebut with any effectiveness. ${ }^{194}$ The most pervasive counter-argument that the St. Josephs-Blatt and the German-American press could find was "War is war," and along with such newspapers as the Express und Westbote, (8/29, 9/3/14); Cincinnati Volksblatt, (9/23/14): Cincinnati Freie Presse, (11/18, 12/9/16); Gross-Daytoner Zeitung, (12/9/16); and the Wächter und Anzeiger, (10/23/15) the St. Josephs-Blatt uses "war is war" as a justification of German action. ${ }^{195}$

Deutsche Soldaten sollen sich wie Wilde betragen haben. Natürlich alle Engländer sind Engel, nur die Deutschen sind Barbaren. Glücklicherweise haben wir Zeugnisse genug von Nichtdeutschen, welche dem Betragen der deutschen Truppen das beste Zeugnis ausstellen. Vergessen wir nicht, Krieg ist Krieg. Ein Soldat muß da gegen seinen Willen Handlungen vollbringen, die ihm widerstehen

191 Blatt 24 May 1915: 1; 28 May 1915: 4.

192 Blatt 27 November 1914: 1. Note that the Blatt did not exempt the French from accusations of brutality and atrocities. The "Gottlose" French, reminds the Blatt, are themselves no gentlemen. They overran Belgium in 1792, ransacking churches and castles, and continued to tyrannize Belgium and treat Belgians like slaves for the next 20 years.

193 Blatt 28 May 1915: 1.

194 Wittke 18.

195 Wittke 18. 
und erst wenn er gereizt und von Zivilisten versteckterweise auf den Soldaten geschossen wird, so mag er sich zu Ausschreitungen hinreißen lassen, die nicht $\mathrm{zu}$ entschuldigen sind. Das sind Ereignisse, weiche sich in alle Kriegen zutragen..... 196

In the same Rundschau, Br. Colestin shows us the strategy which he and many other German-American editors would continue to use in their coverage of alleged atrocities committed by Germans --the countercharge:

...Die Rückseite der Medaille über die von Brüssel und London gemeldeten "Brutalităten" deutscher Zivil- und Militărbehörden bekommt man jetzt in den Berichten belgischer Flüchtlinge, welche auf dem Dampfer "Finland" in New York anlangten. Was hier aus dem Munde vertrauenswürdiger Personen berichtet wird, überschattet in seiner Rohheit alles, was erfinderische Korrespondenten über deutsche Mißhandlungen in den letzten Wochen zusammengelogen haben. Mit dem Einmarsch der deutschen Truppen in Belgien war jeder deutsche Bewohner dort sozusagen vogelf rei und nicht mehr seines Lebens sicher. Johlende Volkshaufen durchzogen die Straßen, plünderten die sămtlich in deutschen Hănden befindlichen Warenhäuser und andere Geschäfte und legten zum Schluß noch die Brandfackel an die demolierten Gebăude. Selbst das bekannte großte Hotel Antwerpens, das sein Besitzer Weber, dem roten Kreuz zur Aufnahme von Verwunderten zur Verfügung gestellt, erging diesem Schicksal nicht, und die Stätte der Barmherzigkeit ist heute ein ausgebrannter Trümmerhaufen. Das dritte Beispiel dieses plötzlich auflodernden Deutschen- und Oesterreicher-Hasses war eine Dame, die, um nicht die Konfiskation ihres in Belgien zurückgelassenen Vermögens herauszufordern, die Angabe ihres Namens verweigerte, aber erzählte, trotzdem ihre zwei in Belgien geborenen Sơhne jetzt für ihre Heimat gegen Deutschland kămpfen, sie, die Mutter selbst, weil sie in Oesterreich geboren, außer Lande verwiesen wurde. Die Verfolgung alles Deutschen erstreckt sich, bis auf die Kinder und Kindeskinder. ${ }^{197}$

The Blatt also attempted to counter the pro-British press accusations of inhumane German treatment of Belgians by publishing articles which detailed Germany's "noble" handling of Belgium. The restaurants in Brussels were said to have been "showered with gold" during the seven hour march through the city. ${ }^{198}$ The Blatt printed a picture showing German soldiers sharing their rations with Belgian orphans and the caption read,

197 Blatt 4 September 1914: 1.

198 Blatt 4 September 1914: 8. 
"Die 'Deutschen Barbaren' -- Ein Idyll aus Feindesland." 199 The Blatt also takes great care in pointing out that if the Germans were behaving as atrociously as they were being depicted by the American press, the Belgians would not be treating them as kindly as they were. For example, a group of 70 Belgian monks, reports the Blatt, transported German wounded from a battlefield and cared for them. Later a group of German soldiers came to the same cloister and were received by the Belgians with water and refreshments. A dying German soldier told one priest there, "Bringen Sie meiner jungen Frau in Aachen die paar Mark noch, die ich habe, und meine Grüße. Ich habe ein Kind, das zweite werde ich nie kennenlernen." The priests there were all willing to help the Germans. "Das sind schöne Züge edler Menschlichkeit inmitten der ruchlosen Barbarei des Kriegs!"200

In the October 2,1914, issue of the Blatt there is a letter; "Kriegsbriefe eines deutschen Landwehrmannes," written from Stoumont, Belgium, August 21, 1914:

Wir sind heute weiter in Belgien vorgedrungen. Nach viertăgigen Aufenthalt in Trois-Pont nahmen wir dort Abschied, hatten nămlich gute Quartiere und hilfsbereite Menschen gefunden. Beim Abschied merkten wir, von welch măchtigem Einfluß dieser kurze Aufenthalt auf unsere Kenntnis des Französischen war, denn, wir konnten unseren Quartierwirten in leidlichem Französisch Lebewohl sagen und sie, die an einer Straße hegen, die wăhrend des ganzen Feldzuges größte Bedeutung haben wird, dem Schutze unserer Armee empfehlen. Ich hatte im Hause eines Eisenbahnbeamten gewohnt; ich drückte der Frau, die von ungewőhnlicher Lebhaftigkeit war und Sprachgewandtheit mit Fixigkeit in hauswirtschftlichen Dingen in glücklicher Weise vereinte, die Hand, versicherte sie unserer aufrichtigsten Dankbarkeit und empfahl sie, ihren Mann und ihre beiden prăchtigen Kinder dem Schutze Gottes. Als ich geendet hatte, brach sie in einem Strom von Trănen aus. Diese auf richtige Teilnahme an unserem Geschick rührte uns tief.... ${ }^{201}$

199 Blatt 1 January 1915: 3.

200 Blatt 25 September 1914: 1.

201 Blatt 4 October 1914: 3; note that page 3 and page 4 of this issue are dated as 2 October 1914, whereas the front page is dated 4 October 1914. Because the next issue is dated 9 October 1914, it must be assumed that the inside dating is correct and not the front page. 
One of the great atrocities allegedly committed by the Germans was the bombardment of the city of Rheims (Reims), France. It is described in the Vom Kriegsschauplatz of 2 October 1914:

Zwei Tage lang haben die Deutschen die alte bekannte franzosische Stadt Rheims, einer der wichtigsten Eisenbahnknotenpunkte Frankreichs, beschossen. Die berūhmte Kathedrale, eines der ehrwürdigsten und schönsten Denkmăler gotischer Baukunst, ist dabei teilweise zerstőrt und derart mitgenommen worden, daß eine Reparatur nicht mehr möglich sein soll. Darüber herrscht in deutschfeindlichen Kreisen wieder großer Zorn und wir werden wieder von deutschen "Barbaren" zu horren bekommen. Wer trăgt aber die Schuld? Wenn die Franzosen sich in der Stadt festsetzten und von dort aus die Deutschen mit Geschossen überschütteten, so blieb ihnen eben nichts anderes übrig, als das Feuer zu erwidern. Oder ist wirklich jemand so naiv zu glauben, daß die Deutschen sich widerstandlos niederknallen lassen sollen! $!^{202}$

This was the first of a number of articles that Br. Collestin devoted to the "destruction" of Rheims Cathedral. In the next issue the Blatt points out first, that it was not yet confirmed that the Cathedral had indeed been destroyed. Then the Blatt gives the German side of the story: the French, after the Germans had decided to give up the city in order to prevent its destruction, moved into the city center with their artillery. French officers set up spotters in the towers of the Cathedral in order to direct artillery fire against the Germans. The spotters were clearly visible in the towers and the German troops were forced out of self defense to fire upon the towers in order to force them out. The German2 Army staff regreted that the Cathedral was damaged in this incident, but the attack on Rheims was a military necessity, because the French made the city a part of the "front." The Germans did only what was necessary and in war that is often difficult and hard. "Wenn man Omeletten will, muß man Eier zerbrechen." 203 In a later editorial, the Blatt complains about France's protests over the "destruction" of the Cathedral by the Germans. The Blatt insists that France had no right to protest. She had allowed more churches to go to ruin and had desecrated more 
churches than any nation in the world. ${ }^{204}$ Rheims remains an issue for the Blatt up through March of 1916 when in the first five columns of the Rundschau Br. Colestin refutes the "barbarism" of the Germans for shooting at and "destroying" the monument. Counter-charges are again brought against France for using one of the towers as a guard tower. ${ }^{205}$

The French were not immune to the accusations of committing atrocities. According to the Blatt, the existence of Dum-Dum bullets in the hands of the French Army was in itself considered a crime against humanity. Germany, despite the denials of the French, had proof that they were being used. Dum-Dum bullets, in their original packing, could be seen in the Foreign Office in Berlin. Some even had an English stamp on them. Furthermore, there were copper-projectiles for "Labelgewehre" which were cut deeply into each side so that they shattered immediately upon impact. Dum-Dum bullets had been found in English and French soldiers' pockets. When a portion of the bullet was removed, it allowed the softer inner bullet to travel further upon impact and inflict then a horrible and unnecessarily cruel wound. Germany had found it necessary to protest in the strongest terms, because these bullets, which according to Art. 23, paragraph 1.e. of the Hague Landkriegsordnung were forbidden, were still being used by Germany's enemies. ${ }^{206}$

The Blatt also exploits its opportunities regarding the German-Americans' new ally, the Irish. Their common animosity to Britain became a common point of agreement. An editorial printed as early as September 11, 1914, mentions that the Irish in New York had sent their sympathy to the Kaiser, his government, and his people, hoping for freedom

Blatt 10 March 1916: 1. 
for Europe from Russian despotism and English greed. ${ }^{207}$ The Irish-Americans, who tended generally to be Catholic, were historically against Protestant England. AustriaHungary, being a staunch defender of Catholic policy in Europe, was a natural ally for the Irish. ${ }^{208}$ They held a strong belief that the Central Powers' defeat of England was the one last hope for Irish freedom from British rule. ${ }^{209}$ The German propaganda machine tried to exploit the Irish desire for independence from England by stirring up as much negative feelings and memories for the Irish as possible. ${ }^{210}$ An article on "homerule" appeared in the Rundschau on October 2, 1914. England had finally passed "homerule" for Ireland, something for which the Irish had been fighting for centuries, but the article reminded the reader that England had sinned against Catholic Ireland for centuries. In order to force Catholic Ireland "zum Abfall," protestant England had sent its war army into Ireland repeatedly with the orders "alles zu tơten, niederzumetzeln, zu vertilgen, zu plündern, zu verbrennen, zu vernichten, wie die Israeliten mit den Kanaanitern getan." Catholics were barred from sending their children to foreign schools; all priests and bishops were banned forever; no Catholic could hold public office or to serve as a lawyer, nor could Catholics was allowed own land, and if he bought some, a Protestant could take it away from him. These were just a few of the injustices the Blatt reported that the "protestant" English had perpetrated on the "catholic" Irish. ${ }^{211}$

207 Blatt 11 September 1914: 4.

208 Rippley 183.

209 Joseph P. O'Grady, The Immigrants' Influence on Wilson's Peace Policies (N.p.: University of Kentucky Press, 1967) 7.

210 Lasswell 177.

211 Blatt 2 October 1914: 1. 
The most vociferous and long-term protests voiced by those Americans trying to keep America neutral were directed at America's extensive munitions trade with England. In the opinion of many the war was actually extended because the United States supplied England and her allies with munitions. The protests against the Wilson administration's one-sided munitions policy came early in the war. In an October 16, 1914, editorial $\mathrm{Br}$. Cölestin demanded "strikte Neutralităt!" about weapons made by Winchester and which had been sent to England a few days before. Br. Colestin noted rather sarcastically that America's neutral stand seemed to be rather advantageous to England since she controlled the seas with her strong fleet. ${ }^{212}$ It was, in fact, the munitions sales to England that kept the question of American neutrality an issue in the Blatt. It became clear to many German-Americans soon after the hostilities in Europe had escalated to war that President Wilson's idea of neutral action was different from their own.

In speeches President Wilson continued to insist that America was doing everything possible to bring the European war to an end. Yet the English, according to an editorial in the Blatt, had asserted that the war in the West continued only because of the imported munitions received by England from the United States. Wilson's acts were becoming more and more culpable and Br. Cölestin insisted Wilson could, if he wanted, end the war. ${ }^{213}$ As much as President Wilson talked about America staying neutral in action and thought, the German-American saw only a continuation and escalation of the war mainly due to continued American munitions trade with England. Most of the protests in the Blatt were full of sarcasm, "unsere Neutralităt ist erweitert worden," claims Br. Cölestin. Not only does the United States ship munitions to "John Bull" but now allows a British officer to come to the United States to observe the construction of a firing range at Cape May Point by the Allies' main munitions manufactuer, Charles

212 Blatt 16 October 1914: 4.

213 Blatt 25 June 1915: 4. 
Schwab. The firing range will be used to test the murder weapons which are to be delivered to the British. ${ }^{214}$

President Wilson was in the center of the munitions controverys by 1915. As far as the German-Americans were concerned as long as the Wilson Administration allowed unrestricted munitions sales to Britain neutrality was unattainable. The Blatt followed the munitions issue closely. In June of 1915 Wilson was assuring visitors to the White House that the United States was doing everything possible to bring the European war to an end. If true, it rang of irony, since the English had said that the war in the west continued only because of American imported munitions. Wilson, if he had wanted, could have ended the war quickly, but because he didn't, his responsibility grew ever larger. ${ }^{215}$

The Blatt protested the shipping of munitions continually. Victory of the "Waffenlieferanten" and "Waffenfabrikanten", with their hearts of stone, was condemned. They were accused of fabricating munitons, bullets, bombs, shrapnel, and grenades, and profitting at the cost of thousands of lives. Br. Colestin wondered just how deeply the materialistic times had sunk. ${ }^{216}$

By August of 1915 the Blatt's editorials were openly accusing Wilson of lengthening the war because of his policies: "Sage da jemand, daß die Ver. Staaten den Frieden in Europa vermitteln werden. --Etwa durch Zusendung von Schrapnells und Granaten?"217

The editorials on Wilson continued:

Amerika zieht durch Munitionslieferungen den Krieg in die Lănge. Wie kann da Präsident Wilson als Friedensfaktor in Betracht kommen, wenn er die Ausfuhr weiter gestattet? 218

214 Blatt 6 August 1915: 4.

215 Blatt 25 June 1915: 4.

216 Blatt 23 July 1915: 1.

217 Blatt 20 August 1915: 4.

218 Blatt 17 September 1915: 4. 
Onkel Sam liefert den Alliierten Munition, Waffen, Năhrungsmittel und vielleicht auch Geld. Jetzt braucht er ihnen nur noch die Menschen zu liefern, damit man von seiner Neutralităt vollkommen überzeugt ist. ${ }^{219}$

President Wilson's prejudice against Germany was quite apparent to the editor of the St. Josephs-Blatt. The President is accused of endangering American lives by allowing American citizens to travel on munitions ships bound for England, while warning them to stay clear of Mexico, because of possible danger. The disparity in foreign policy convinces Br. Collestin of President Wilson's predisposition towards England. The Blatt explains that Wilson wants Americans on the ships in order to hinder their sinking by Germany. ${ }^{220}$ "Weshalb die Abneigung gegen Deutschland, Herr Präsident?" On August 15, 1915, the State Department warned Americans to stay away from Mexico, because of the dangerous conditions existing there. This stood in direct contrast to what President Wilson was saying regarding Germany. The Blatt questioned Wilson's motivation and then supplied its own answer. As far as Br. Cölestin was concerned, President Wilson's policies toward Germany were so incomprehensible that they no longer even surpised him. How President Wilson could justify forbidding Americans to travel to Mexico because something could happen to them, but then allowing them to travel with English munition ships, in order to hinder their sinking by the Germans, was inexplicable to the editor. ${ }^{221}$

The controversy over the shipment of munitions by the United States became a major issue by 1916. Besides simply accusing President Wilson and the American munitons manufactureres of extending the war, the issue proved to be motivated by greed. ${ }^{222}$ American weapons manufacturers were accused of getting rich from war

219 Blatt 1 October 1915: 4.

220 Blatt 24 September 1915: 4.

221 Blatt 24 October 1915: 4.

222 Blatt 23 February 1916: 4. 
production al in the name of neutrality is mentioned in the Rundschau of January 1 , 1916. Wilson's administration is blamed for it all. ${ }^{223}$ In an editorial of February 4 , 1916, "Munitionsfabrikanten," according to one Senator Cummins of Iowa, are criticized as dangerous men. Not everyone wanting profit from war is, but these men and corporations are not capable of "Zwistigkeiten zu beurteilen die zum Konflikt führen können." They should be removed from business. The government should make it impossible for men and corporations to earn money through the war. Above all, we need the rebirth of Americanism; that means "Treue" to pride and our past and trust in the future. It means a spirit in men to live for the country and if necessary to die for it. $^{224}$

Another Senator is quoted as saying the munitions suppliers on the east coast were pushing the United States into war and on the side of the Allies. The East is war crazy, because the munitions manufacturers are making millions, according to Senator Lawrence Sherman from Illinois, in a speech at the Union League Club in Chicago. He points out that in the preceding 14 months more millionaires had been created east of Pittsburg than in the preceding 14 years. $95 \%$ of the profits came from weapons and munitions. ${ }^{225}$

England is directly accused of enticing American citizens, including GermanAmericans, onto munition ships in order to protect them from German attacks, especially by submarines. In a box at the bottom of column two of the March 17, 1916, Rundschau the following ad appears in English:

Wanted.

Citizens of the United States to embark on British ships through the war zone.

223 Blatt 1 January 1916: 1.

224 Blatt 4 February 1916: 4.

225 Blatt 31 March 1916: 8. 
Only such Germam-Americans whose naturalization papers are in perfect order may call. Full particulars at Rua 24 de Maio, No. 2.226

The ad appeared in the paper A Tribuna in Santos, Brazil on September 13, 1915. According to the Blatt, England wanted as many Americans on her ships as possible for security. The address that appears was the General Consulate of England. Br. Colestin wonders what President Wilson would say to this shameful act, pointing out that Sweden had forbidden her countrymen from traveling on armed ships, and wonders why America didn't do the same.

Few political cartoons were used in the Blatt, but one did appear in the March 31 , 1916, issue. In the upper right hand corner, page 7, an American family is depicted as sitting on a box on a ship. The box is labeled "Ammunition to Liverpool." The caption reads: "By using all means and promises the English are trying to get Americans as passengers on their ships as protection so that Germany won't sink the ships carrying ammunitions. The ammunition is more important than the lives of Americans." 227

England took extraordinarily quick and extensive measures to stop as much trade between Germany and her allies as possible. These measures included halting whatever contraband they believed was headed to the Central Powers, whether shipped by neutral countries or not. This included the United States. The American government did little in demanding the right of free trade on the high seas by neutrals, at least in the opinion of German-Americans. ${ }^{228}$

The British blockade was very effective in keeping supplies from neutral countries in Europe. It was also affecting American commerce. Many Americans, whether of German descent or not, began to protest Wilson's lack of decisiveness in dealing with

226 Blatt 17 March 1916: 1.

227 Blatt 31 March 1916: 7.

228 Wittke 49-50. 
England and demanding the country's trading rights. The Blatt makes its own demands for action from Wilson against England's "Übergriff." The neutral nations' rights to trade must be protected and unrestricted trade between neutrals must be allowed.

The government did receive some praise in the article titled, "Beginnt sich unsere Regierung endlich auf die Einhaltung einer ehrlichen Neutralität?" Finally the State Department had sent a protest letter to England. High marks, however, were not given. The Blatt complained that the protests sounded like apologies and $\mathrm{Br}$. Colestin demanded more decisive action. ${ }^{229}$

"Das Wort 'Neutralităt' ist eigentlich ein Hohn" if we consider the actions of our government, begins another article. The Allies are allowed to export war material with falsified declarations but if someone travels to Germany with "rubber articles" (Gummiwaren) in unmarked cases, that is considered a break in neutrality. Supposedly, persons traveling to Germany have the idea to sell these rubber items there for a profit. "Das ist eine Gesetzübertretung," says the head "Schnüffler" of the Justice Department. Strange that it is not forbidden to export these items but they consider it smuggling. The crime is that they didn't mark their case, in order to make it easier for the British to confiscate it. The breaking of neutrality is that the Allied governments could take it badly to have this war contraband shipped from the United States to Germany even though they themselves send it in large quantities to England and France. One is always learning, especially what American neutrality is under the Wilson administration. ${ }^{230}$

An editorial of the same day suggests that England no longer is allowing the shipping of medicine from the United States to Germany, Austira-Hungary, Bulgaria, or

228 Blatt 8 January 1915: 1.

230 Blatt 7 January 1916: 3. 
Turkey. Before it was just rubber-articles that were kept from the sick, now it is everything. Br. Colestin calls this "English humanity!"231

Part of the problem was deciding what was contraband and what was not. It had been quite clear by 1916 that the British blockade was effective and the shortages of food and other material in the Central Powers had caused some major problems in Middle Europe. ${ }^{232}$ The Blatt argued that the blockade was illegal and should not have been permitted by the United States. Its arguments were traced all the way back to Thomas Jefferson. A special feature in English appeared called "Jefferson's neutrality." Jefferson lays down the rule in the simple proposition that the duties of neutrality require equal conduct to both parties, meaning of course, the parties at war. Jefferson denies that food stuffs were considered contraband and is quoted:

"It suffices for the present action to say that corn, flour and meal are not of the class of contraband, and consequently remain articles of free commerce--We see then, a practice begun which strikes at the root of our agriculture, that branch of industry which gives food, clothing and comfort to the great mass of the inhabitants of the state.... If we permit corn to be sent to Great Britain and her friends, we are clearly bound to permit it to France. To restrain it would be a partiality which might lead to war with France and between restraining it ourselves, and permitting her enemies to restrain it unrightfully is not different....This is a dilemma which Great Britain has no right to force upon us. She may indeed feel the desire of starving an enemy nation, but she can have no right of doing it at our loss, or of making us the instrument of it." ${ }^{\text {233 }}$

As part of the reaction of Americans against the Allies, especially England's prohibition of certain contraband being shipped to Europe, was a call for an embargo against trade with England. The purpose was twofold: one, to show America's resolve to protect her shipping rights as a neutral country, and two, to halt the export of war materials and munitions to the Allies. The embargo was seen as a means to end or at least to shorten the war. As part of the embargo campaign, the Blatt printed a special

231 Blatt 7 January 1916: 4.

232 Wittke 51 .

233 Blatt 3 March 1916: 4. 
feature "Schreibt sofort!" calling on all citizens who have the desire that the war be ended soon, to write to their representatives in Washington and pus for an embargo. The following letter was given in English as one that could be used:

Dear Sir:

As I am very anxious to see our country maintaining a position of neutrality, so definite and absolute that it cannot be questioned by any one whose sympathies are for either of the belligerents of Europe. I am appealing to you, my representative in Congress, to support the resolution ordering an embargo upon further shipments of war material, when it comes up for consideration.

A number of friends join with me in this appeal and I ask that you be good enough to favor me with an early answer so that I can announce to them your attitude.

Trusting that you will not allow us to suffer disappointment over any vote of yours, I beg to remain,

Very respectfully yours,

Name

Address

City, State. ${ }^{234}$

As part of a national movement this letter writing campaign was so successful -over two million signatures were collected nationwide-- that those with pro-British sentiments saw a "pro-German" plot in the effort and immediately cried foul, along with treason. ${ }^{235}$ The Germans were accused of trying to help Germany by "putting her interests above those of the United States. ${ }^{236}$ The campaign was designed to counter President Wilson's un-neutral stand relating to Germany. The prohibition of contraband by England had begun to take a major toll on American industry and agriculture, and because Wilson continually refused to interfere he was perceived to be pro-British. Along with this, because of the fact that other sectors of America's munitions manufacturing industry were producing millionaires, many saw Wilson's rejection of an

234 Blatt 28 January 1916: 8.

235 Rippley 182.

236 Wittke 64. 
embargo as pro-British. This stand against an embargo became one of the major issues that would follow Wilson throughout his presidential re-èlection campaign of $1916 .^{237}$

On May 7, 1915, the British ship Lusitania was torpedoed by a German submarine. On board were 1,195 civilians, including 128 Americans. The first article in the Blatt on the tragic sinking was two weeks after the incident. There was no glee on the part of the Blatt, as was the case in many German-American papers, only the fear of Wilson's capitulation to the pro-British press's demand for a declaration of war against Germany. ${ }^{238}$

The Rundschau begins with an admonition directed at the American government, which, according to published reports, despite everything, chose to ignore Germany's warnings of imminent danger to all civilians on board British ships carrying munitions. ${ }^{239}$ The sinking of the Lusitania, on which at least 128 Americans lost their lives, brought the war to America's door. The pro-British press was hounding President Wilson to declare war. Politicians, such as ex-President Roosevelt, calling the entire German nationa "Răubervolk," demanded that Wilson take immediate steps against Germany. Br. Cölestin's position was: "...der Vorfall ist absolut kein Anlaß für eine Kriegserklärung, ${ }^{240}$ but he recognized the danger ahead. American public opinion was so inflamed against Germany that the editor, like so many other German-American newspaper editors, knew that America stood on the very brink of war with Germany. The Blatt joined the rest of the German-American press in a campaign to justify Germany's act.

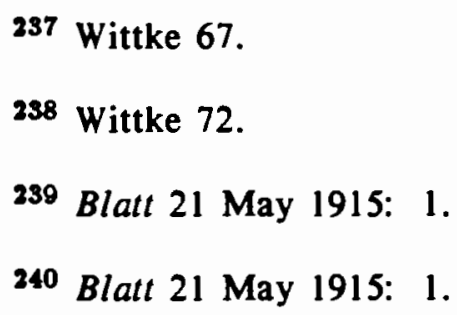


In the May 21, 1915, Rundschau the Blatt gives an account of the incidents that preceded the sinking. On February 18 Germany announced the beginning of submarine warfare and declared a war zone around England. The German ambassador let the passengers of the Lusitania know about the danger before their departure. On the day of departure, it was disclosed that the steamer would be torpedoed, but the warning was laughed off as a German "bluff." According to the British, the speed and construction of the Lusitania would protect her from any attack. Br. Colestin described the British actions as part of a perfidious, callous plan to involve the United States and German in a war. ${ }^{241}$

The Rundschau questions America's right to lay the responsibility for the sinking of the Lusitania on Germany. The Blatt declares that if England had the right to declare a war zone in the North Sea, then Germany had the right to declare English waters a war zone; Germany was fighting a war for its existence; the Lusitania was carrying munitions and explosives and that in itself was a crime against the passengers. It also gave Germany the right to sink her. The English Admiralty had done nothing to bring the Lusitania to port though they knew she carried passengers. ${ }^{242}$ These and similar arguments appeared in almost all of the German-language papers in the country following the sinking. ${ }^{243}$

The two most important issues, according to the Blatt, were the munitions the Lusitania carried and the warnings against embarking on the voyage given the passengers before departure. The editorials of May 21, 1915, reflected these points:

241 Blatt 21 May 1915: 1.

242 Blatt 21 May 1915: 1.

243 Wittke 73. 
Die Lusitania führte Munition und Explosivstoff als Fracht -- ein Verbrechen, welches den schărfsten Tadel verdient. ${ }^{244}$

Die engl. Regierung war Miteigentümerin der Lusitania; das Schiff führte Kriegsmaterial und fuhr in die von den Deutschen erklărte Kriegszone und das war für die Deutsche Ursache genug es zu versenken. ${ }^{245}$

Titanic und Lusitania, die grőßten Dampfer Englands sind blindlings dem Untergange entgegengeeilt. Die Titanic war ein "unsinkbares" Schiff und glaubte den Elementen trotzen zu kőnnen; die Lusitania war eindringlich vor der ihr drohenden Gefahr gewarnt worden, umsonst, der Befehlshaber des Kolosses spottete über den deutschen "Bluff". 246

The Blatt also publishes in the same issue a reprint of the warning issued by the German Embassy on April 22 more than a week before the Lusitania's fatal departure:

Reisende, welche sich zur Reise über den atlantischen Ozean einzuschiffen beabsichtigen, werden darauf aufmerksam gemacht, daß zwischen Deutschland und seinen Verbündeten u. Großbritannien und seinen Alliierten ein Kriegszustand herrscht: daß die Kriegszone die an die britischen Inseln grenzenden Gewăsser umfaßt; daß in Uebereinstimmung mit der von der kaiserlichen deutschen Regierung erlassenen formellen Bekanntmachung Schiffe, welche die Flagge Großbritanniens oder eines seiner Verbündeten führen, in diesen Gewăssern der Zerstőrung gewărtig sein müssen, und daß Reisende, welche in der Kriegszone auf Schiffen Großbritanniens oder seiner Verbündeten fahren, dies auf ihre eigene Gefahr tun. ${ }^{247}$

It was the British whom the Blatt took to task. The loss of the 128 Americans is attributed to the British desire to make Germany and the United States enemies. The fact that the Lusitania carried 5,471 cases of munitions along with other military supplies with a value of $\$ 166,000$ and 280,000 pounds of brass and copper wire and other contraband made the ship unsafe for passengers, yet the British actively contributed to their recruitment by promising that the ship would be escorted and protected by British

244 Blatt 21 May 1915: 4.

245 Blatt 21 May 1915: 4.

246 Blatt 21 May 1915: 4.

247 Blatt 21 May 1915: 5. 
warships. This was criminal behavior, in the eyes of the German-American press, and it deserved the severest retribution by the United States. ${ }^{248}$

Germany's actions, on the other hand, are reluctantly, but clearly justified by the Blatt. Br. Cölestin argues that enough munitions were shipped on the Lusitania to kill at least 100,000 Germans. Germany had repeatedly warned passengers on any ship sailing to England that traveling on such ships was dangerous. Germany had also declared unlimited submarine warfare, and the Blatt believed that Germany had no choice but to continue in its course as long as England was carrying out its plan to starve the civilian population of Germany, and as long as England insisted that the United States could only ship her grain to England, but had to halt all commerce with Germany and other neutral nations. ${ }^{249}$

Articles in the Blatt reflected the uncertainty and fear felt by many GermanAmericans in 1915. For the first time the United States had reached a point where war with Germany was a real threat. Many German-American newspapers reflected on where their readers would stand if war were declared, claiming that all German-Americans were American first and in the case of war would fight for America. ${ }^{250}$ Other papers, like the Blatt, demanded fair treatment for Germany while reflecting on the justness of a possible war with Germany.

The May 28 issue of the Blatt added more fuel to the issue of Britain's guilt in the Lusitania sinking. According to a congressman Hobson (Kutzbold) a cousin of his had been set to book passage on the Lusitania, but had decided not to after she was taken aside by a friend, an agent of the Cunard Line, who told her that under no circumstances was she to book passage. He told her that the ship was under the

248 Blatt 21 May 1915: 5.

240 Blatt 21 May 1915: 5.

250 Wittke 74. 
command of the British Admiralty. She promised to keep this information secret until after the ship's departure.

Congressman Hobson then posed a number of questions to his congressional colleagues. Why had the Cunard Line not warned all the passengers who wanted to sail with the Lusitania instead of just his widowed cousin? Why had the British Admiralty, which knew that German submarines were operating off the south shores of Ireland, not let the Lusitania take a less dangerous course? Why had the ship received orders from the Admiralty to travel no faster than 17 knots in the danger zone, when the ship had been capable of 25.5 knots? How could a torpedo have sunk such a ship in 20 minutes? Congressman Hobson believed that anyone knowledgeable of ship architecture would have known that there had to have been another cause inside the ship, an inside explosion, for example.

His questions continued: Why had no escort ship been in the danger zone for the ship's protection? Why had there been no escort ships there to help in rescue operations? Why had it taken so long for help to arrive ${ }^{251}$ Hobson asserted that Germany had had no desire to kill Americans, but had tried to save American lives by warning them. England, on the other hand, had a major reason for wanting American lives lost: to knock America into war with Germany. Hobson demanded an unbiased investigation into all the allegations and due process for Germany. He ended his speech with an affirmation of America's willingness to fight, as a Christian nation, in a just war. America, asserts Hobson, fears only God and shuns His rage. ${ }^{252}$

The case of the Lusitania finally begins to appear less often in the Blatt and in a final note, Br. Collestin declares that he doesn't believe Germany could accept the conditions sent to Germany by President Wilson as long as England continued her war 
policies. Br. Collestin declares that the entire Lusitania case was still so unclear as to preclude any rational judgment. ${ }^{253}$

In July of 1915, the Blatt begins a series of articles and features on the problems facing German-Americans and their endeavors to protect and maintain their cultural heritage in the United States. By 1915 anti-German sentiment had begun to show signs of reemerging as a major problem in the United States. Br. Cölestin sensed a need to begin efforts to affirm the importance of German heritage and tradition in the United States. As in past articles in which the Blatt praised German culture in the United States, the most effective means Br. Cölestin could use to catch the attention of his readers was the German language. The idea that "language saves faith" was still germaine to most of the German-American Catholics in the United States in 1915. The fact that German-Americans were threatened with the loss of their cultural identity was not lost on Br. Collestin. This was an issue which he could use very effectively.

The front page of the July 2, 1915 issue begins with a poem called "Die deutsche Sprache in Amerika." The poem reads as follows:

Du bist kein Fremdling in der Freiheit Lande Mein deutsches Lied, das voll und kühn erklingt Und bist du ferne auch vom Heimat Strande. $\mathrm{Zu}$ tausend Herzen eilst du leicht beschwingt: Mit allen einen dich die schönsten Bande. Durch welche je ein hold Geschick verschlingt: Die deutsche Sprache ist's, die uns verbindet. Ob Lust ob Leid das Lied des Sángers kündet.

Du bist kein Fremdling; viele Millionen Sind, fern von Vaterland, von Herzen dein. Und über all, wo deutsche Herzen wohnen, Bist du ihr Kleinod, du ihr Edelstein! Wir beugen uns nicht mehr vor Fürstenthronen, Vor dir, o Muttersprache, nur allein.

Mit jenem ersten Lied, das hell erklungen, Hast du auch hier das Bürgerrecht errungen.

Was kann, wie Du, so warm und hold erklingen, 
$\mathrm{Zu}$ pfeifen, was da groß und schön erblüht?

Was kann, wie Du, so wunderbar besingen,

Was in der Seele tiefverborgen glūht?

Ihr, deutsche Laute, könnt das Herz bezwingen

Denn ihr allein seid Seele und Gemüt!

Ihr seid die edelste von allen Gaben,

Die wir an diesen Strand getragen haben!

Mőgt ihr die Kühnen Pioniere preisen,

Die fleiß'ge Hand, die froh die Scholle baut,

Den, der da schürft der Berge Gold und Eisen,

Den, der da forschend zu den Sternen schaut.

Ich heb' auch sie: singt ihnen Rühmesweisen.

Doch ich will preisen deutscher Sprache laut!

Mein bestes Kleinod, in dem Land der Freien.

Fr. Alb. Schmidt ${ }^{254}$

Br. Cölestin points out, in a later editorial, that in 1913 more books were published in German than in English and French combined. He wonders why then in 1915 the use of German in the United States had diminished. Some people, claimed the editor, blamed the schools and churches, but he points out that the language must be spoken at home as the children's first language, before it can be taught in schools and used in the churches. Teaching children in German, when they come to school without a word of German in their vocabulary, would be like teaching them in Chinese or Japanese. The guilt, Br. Colestin preaches, lies with German-American parents. It is their responsibility to be sure the first language their children learn is German. English, he says, can be learned on the streets. ${ }^{255}$

In a subsequent article called "Deutsche die Weltsprache," Br. Cölestin quotes Houston Stewart Chamberlain, a naturalized Englishman living in Germany, who had written an article in "Die Internationale." No date for Chamberlain's article was given. In it he called the German language "ein lebendiges Kleinod das von Gott geschenkt ist..." Chamberlain is cited as believing that it was very important that German and not 
English become the world language. If English predominated, he claimed, humanity's culture would stand before closed doors, and that would mean its death. Those who do not speak German then are as good as "ausgestossen von der menschlichen Gesellschaft." ${ }^{\text {256 }}$

The German language theme is continued in another special feature: "Die deutsche Sprache." It is almost a repetition of the October 1, 1915 editorial cited above, with added emphasis on the importance of German being spoken by more than $80,000,000$ people in 1916. In the United States, however, the use of German had diminished significantly. Br. Colestin questions why so few children in German homes spoke German and why their parents allowed this to happen. So of ten, claims Br. Collestin, children find the German language a burden and it is then thrown overboard. When this happens, however, something very important, "deutsche Zucht, Sitte, Charakter, Eigenart und Wesen des Deutschen" is also thrown overboard. With it goes a worthy means of character building of the American people. Br. Cölestin even postulates in English that "[t]he more languages you know, the more man you are."

Language, continues the article, forms a key which opens the inner self to the world. It is a known fact that wherever the German language is heard there rules a certain "Gerechtigkeit, Ordnungssinn, Genügsamkeit, Sparsamkeit, Fleiß und Ausdauer." There is no "fleißigeres" intelligent and "beharrlicheres" people as the Germans. When one enters a traditional German home, one is met with a certain simplicity, together with cleanliness. The mother takes care of her house duties and when the tired husband comes home he will find his supper hot and ready. The daughter stands by mother's side smiling, supporting her in the kitchen, using the sewing machine, and doesn't shy away from the washing machine. This is the home of the German Language. 
We enter another German home and immediately believe we made a mistake. The house is dirty, there is nothing in the refrigerator. The son doesn't work and the daughter--o! how awful. The mother is to blame because she forgot to teach her children the German customs; she banned the mother tongue, she neglected the German virtues when the children were small; she turned her back on the German church because it wasn't "stylish" enough. She will eventually regret this and will remember her own Father and Mother and their good German ways--but too late! ${ }^{257}$

As part of the Blatt's efforts to shore up the diminishing power of German culture Br. Colestin also reports on the reemergence of "nativism" in the United States. In an editorial, the paper regrets the loss of "[d]ie schonen, freien Tagen in Amerika..." America had become a different country with "Heuchelei, Engherzigkeit, und Nativismus" celebrating their triumphs at the expense of the Constitution. Br. Corlestin illustrates this by examining a Pennsylvania law forbidding the un-naturalized, foreign born from owning dogs. It was signed into law by a Pennsylvania Dutch "abstammenden" Governor. The law, described as absurd, reads:

Es soll für jeden nichtnaturalisierten, im Auslande geborenen Bewohner des Staates ungesetzlich sein, entweder einen Hund zu halten oder im Besitze eines solchen gefunden zu werden. Die anwesenheit eines Hundes in eines Zimmer, in einem Gebăude, in einem Zelte oder in einem Lager, das von einem nichtnaturalisierten, im Auslande geborenen Bewohner eingenommen oder kontrolliert wird, soll als prima facie Beweis dafür gelten, daß ein solcher Hund von der Person, welche das Grundstück, in welchem der Hund gefunden wird, einnimmt oder kontrolliert, besessen oder kontrolliert wird. ${ }^{\mathbf{2 5 8}}$

A $\$ 25.00$ fine or imprisonment for a day for each dollar not paid was to be levied against those found in violation of the law. Dogs found in the possession of unnaturalized aliens would be confiscated and, if not worth anything, killed. ${ }^{259}$

257 Blatt 14 July 1916: 4

258 Blatt 2 July 1915: 4

259 Blatt 2 July 1915: 4. 
In the Rundschau of July 9, 1915 German-Americans were again the subject of an article this time concerning the newly introduced "Amerikanisierungstag."

Da soll denn doch gleich das Donnerwetter dreinfahren, und die denkfaulen Amerikanern mit und ohne Bindestrich zur Raison bringen. Es ist irgendwo einem Pro-Briten oder einem Feinde der Deutsch-Amerikaner der absurde Plan eingefallen, an Stelle der ublichen Feier des glorreichen Vierten ein Amerikanisierungstag zu feiern u. merkwürdig gab es noch Deutsche, sogar in Oregon, dies zu dem Plane Ja und Amen sagten. Das ist eine Schande. Wir brauchen keinen Amerikansierungstag: wir sind gute Amerikaner, ob unsere Wiege in Deutschland, Osterreich, Ungarn, in der Schweiz oder in irgendeinem anderen Lande Europas gestanden hat und wir werden auch immer unsern Mann stellen, wenn es notwendig werden sollte, die Unabhăngigkeit der Ver. Staaten zu verteidigen. Wozu also einen Amerikanisierunsgstag? Wir wollen die Antwort geben. 260

In short, the Blatt insisted that this "Amerikanisierungstag" was the idea of pro-British, who were heavily represented in the editorships of American newspapers. Historicallly, the 4 th of July celebrated the independence of the colonies from England. Now the plan was to replace the usual celebration with the "Amerikanisierungstag," so that the people in 1915 would no longer remember the "Willkürherrschaft" of England over the colonies. Br. Cölestin wanted the American people to remember that their most prized possession was the Declaration of Independence by Thomas Jefferson. ${ }^{261}$

The Blatt praises the patriotism of German-Americans in a special article on October 29, 1915. Titled "Wir Deutsch-Amerikaner sind die Besseren Patrioten, Herr Wilson!", the article, basically an answer to a speech given by Wilson in 1915 in which he suggested that there should not be such a thing as hyphenated Americans, takes the President to task for calling the patriotism of any hyphenated American into question.

Br. Colestin points out that it was hyphenated Americans (among whom Germans proudly counted themselves) who led the battles and fought to make this an independent country. He chides President Wilson to name just one German who in the hour of 
danger had let his adoptive land down or betrayed it! German-Americans remain true loyal citizens of the Union. "Wem das night passt, der kann uns den Buckel hinaufsteigen." 262 "Machen Sie die Augen auf, Herr Wilson!" It was unforgivable of President Wilson to have called the patriotism of every German-American into question. It as unheard of in the history of the Union. If he had opened his eyes, and had wanted to be persuaded about German-American loyalty, he needed only to have gone through the registers of state militias. There he would have discovered German name after German name. In large cities, almost 50\% were of German ancestry. In Oregon it was a good German, Max Gehlhar, who as commandant of the National Guard brought Oregon to war readiness. In St. Louis it was hyphenated German-Americans who offered to form a regiment and arm it. Those were the people whom the Democratic convention had insulted at the request of the White House--the same people Wilson had denounced in many speeches as disloyal. Open your eyes, Mr. Wilson, and correct the gross injustice you committed on millions of loyal citizens. ${ }^{263}$

In 1916, a presidential election year, the Democratic party took up the problem of the hyphenated American. In the June 30, 1916 Rundschau the so-called "Bindestrich Planke" of the Democratic Party platform was challenged by Br. Cölestin. He quotes the plank in English:

In these days of trial for our people all "Partweiwesen" should be set aside. The nation should become a nation of patriotism. In America the best of the blood, industry, and genius of the world come together to make a strong and wonderful nation. And those who would subvert our country by working for a foreign power to the detriment of our country's interests by awakening prejudices against race, religion and other things that hinders unity in our country is a traitor to our land. We therefore condemn as shameful for the integrity of our country the activities of any groups or organizations, political or otherwise, through which the interests of a foreign power are to be furthered.

We condemn the alliances and combinations of individuals of this country, whose nationality or heritage are the same, who unite together or swear in order 
to weaken our government, or to influence the representatives of our government who must work with foreign nations.

We maintain that such organizations exist and we condemn every political party which in view of such members, modify their policies or sacrifice its integrity. 264

The Anti-Hyphen plank is condemned as nothing but an acute "...Wutanfall, eingeschnürt in Phrasen, die dem Wissenden etwas tiefes bedeuten sollen, aber in ihrer allgemein verschwommenen, schlüpfrigen Fassung die Furcht anzeigen. ${ }^{\text {265 }} \mathrm{Br}$. Cölestin rephrases parts of the English text into German for his readers:

Wir verdammen die Tătigkeit und die Plăne jeder Gruppe oder Organization, politischer oder songstiger Art, deren Zweck es ist, die Interessen einer auswărtigen Macht zu fördern.

Wir verdammen alle Allianzen und Kombinationen von Individuen in diesem Lande, gleichgültig von welcher Nationalităt oder Abstammung, die miteinander such vereinigen und konspirieren, im unsere Regierung in Verlegenheit zu setzen oder zu schwăchen, oder unsere offentlichen Reprăsanten zu beeinflussen oder Zwang auf sie auszuüben bei ihrer Negotiationen mit einer fremden Macht.

Wir erheben die Beschuldigung, daß solche Verschwörungen...existieren und daß dieselben angestiftet wurden, um die Interessen fremder Länder, zum Schaden und Nachteil unseres eigenen Landes zu fördern. ${ }^{266}$

Br. Colestin agreed with the stipulations of the plan completely. He maintained that he had always criticized and condemned such organizations and alliances. Certainly such "conspiracies" existed, not among German-Americans or any other hyphenated Americans, but instead between newspapers like The New York Times, World and Providence Journal that supported the interests of England, France and Russia, and in doing so damaged the integrity of the United States. The conspiracies were designed to sow dissatisfaction and hate among the citizens of the United States, in order to denounce, intimidate and threaten honest rightly thinking citizens. ${ }^{267}$ The Democratic 
platform was part of President Wilson's campaign for reelection. He naturally had the advantage of being the incumbent, but the Presidency was not his for the taking. He recognized the need to mollify those factions in the Democractic Party which did not agree with his policies on neutrality and war. The German-Americans, as well as many other hyphenated Americans, were abandoning their traditional allegiance to the Democratic Party in favor of candidates more in tune with their ideas of neutrality.

President Wilson's reputation in 1916 with these traditionally democractic groups was at an all time low. Wilson was known as a loner, a "Selbstherrscher," someone who felt no need to listen to Congress. Br. Cölestin believed it was time for a change in administrations. Almost all the blame for America's inability to trade competitively with other neutral powers was put on Wilson's shoulders. Basically, the Blatt attributed the continuation of the war in 1916 to Wilson and his inability to govern effectively. $\mathrm{Br}$. Cölestin's language in the reports and editorials on Wilson was harsh, condemning, and unrelenting. In 1916 he used every opportunity to rail against Wilson, members of his administration, and his policies.

Of all Wilson's policies, his position on American neutrality was still the most controversial in 1916. German-Americans found his strategies in dealing with England and Germany distinctly biased on the side of Great Britain. Some German-American editors pronounced his submissiveness to English demands as a surrender of American neutral rights. Others denounced his administration's execution of its own policies as one-sided, sloppy, subjective, ineffectual, and decidedly unneutral.

In a special article titled "Besteht eine geheime Allianz zwischen England and den Ver. Staaten?", the Blatt endeavors to prove that there was more and more evidence of a secret treaty between England and the United States. The many millions of dollars of Andreas Carnegie and the propaganda of the Anglophiles had supposedly borne fruit. It was reported that statesman Joseph Chamberlain had spoken about such a secret treaty in 
Parliament, shortly before his death. However, a decision by United States Labor Secretary William B. Wilson (October 9,1915$)$ more clearly illuminated the probability of such a secret treaty: The question arose as to whether or not an American would expatriate himself if he enlisted in the Canadian army. A bureau letter of October 9 , 1915, No. 54.003.431, stated that "the boards will not question the American citizenship of an applicant because...he took the oath of allegiance and enlisted in the Canadian forces." (Quoted in English in the Blatt.)

The power of this decision for Br. Colestin was that an American could renounce the American flag, become a vassal of King George of England and risk his life form him, yet could remain a citizen of the United States. Upon his return he would receive the same rights as those citizens who had remained true to their country. And who made this decision? William Bauchop Wilson, born in Scotland on April 2, 1862--who had emigrated to the United States and who was a member of President Wilson's cabinet. Br. Cölestin bet that the decision was unconstitutional:

Wir wollten den Zorn des Präs. Wilson und das Huronengeheul der probritischen Presse hören, wenn deutsche Amerikaner versuchen sollten, unter denselben Bedingungen sich für Deutschland anwerben zu lassen! ${ }^{268}$

Br. Collestin demanded that Congress let the Secretary know he cannot make decisions which counteracted the Constitution.

Another controversy involving President Wilson and his policies of neutrality in 1916 centered around the shipment of milk to Germany. Early in 1916 the Blatt reports that France decided to forbid the export of milk to Germany. The editorial on the subject pointedly questions President Wilson on his position on this "himmelschreiend" and "unerhört" idea: children were being allowed to die of malnutrition because the 
export of milk was interdicted, while munitions exports were not only allowed but demanded. ${ }^{269}$

Pres. Wilson was approached by many people and groups requesting his intervention in the fracas over milk exports. It was reported by the Blatt in a special feature on June 16, 1916 called "Tabak und Zigarren fur die allies, aber keine Milch für die deutschen Kinder," that he refused to intervene. Pres. Wilson was ridiculed for his "humane" decision to allow packets of tobacco, cigars and cigarettes to be sent to soldiers in England, Belgium, and France, free of charge, yet when bombarded from all sides asking him to allow milk to be sent to infants in Germany he turned a deaf ear. ${ }^{270}$ Not surprisingly, the Germans took this propaganda ploy as far as possible. A "Citizens' Committee for Food Shipments" was formed in 1916 and was definitely proGerman. Created by Dr. Edmund von Mach, it existed ostensibly to supply the children of Germany with condensed milk. The Committee was a failure as a source of milk and as propaganda, basically because the story of starving infants in Germany was debunked by both the American State Department and American and foreign reporters. ${ }^{271}$ Yet Wilson's administration received a lot of criticism because of its apparent lack of feeling for the children of Germany. The Secretary of the Navy refused to allow the milk collected by the Committee to be shipped on an American warship. This refusal to ship milk combined with the consent to help ship munitions to England was protested heavily in citizens' meetings in many cities throughout the United States. ${ }^{272}$

The apparent milk crisis in Germany prompted a Rundschau decrying the American government's friendship with England. Br. Collestin was no longer surprised when

Blatt 28 January 1916: 4.

270 Blatt 16 June 1916: 7.

271 Lasswell 35.

272 Wittke 51 
something happened for England which injured American neutrality. He was not surprised when he heard how the government would not offer a helping hand to bring milk to the German people--milk which the generous people of the United States had collected. The Blatt accused England and France of fighting an "Ausrottungskrieg" against the newly born generation of Germans. The United States was found guilty of complicity, because it supported the brutality of the Allies. And so went the "unparteiisch" story of Americans as deliverers of war materials and as accomplices to the "Ausrottung" of the children of Germany. Oh, cried Br. Colestin, if only a Washington, Lincoln, Cleveland, or Jefferson stood at the helm of our government! It was hard times for GermanAmericans, but this too would pass. Even this would not cause German-Americans to take illegal steps, promised the editor. He regretted and criticized the position of the government, which as a citizen he believed he had the right to do, and still remain a true and law-abiding citizen of the Union, which the Anglophiles could use as an example. ${ }^{273}$

The Rundschau of March 17, 1916 begins with a disclaimer that no American citizen criticizes the President of the United States gladly. The Blatt had kept quiet about a lot of Wilson's rhetoric, but on this day no American could keep quiet who did not want to see the United States involved in war. Thus the Blatt reports how, in a meeting with Senator Stone, Chairman of the Foreign Affairs Committee, Wilson was told that only Congress had the right to declare war. Wilson reportedly said that it was in the best interests of the United States to enter the war on the side of the Allies. Mr. Stone, to the surprise of the President, pounded his fist on the table and declared that this was the point where he broke from the President. ${ }^{274}$ 
In another part of the same Rundschau the Blatt reports that the United States was not enveloped in a war thanks only to the patience of Germany:

Es sind eine ganze Menge Beweise vorhanden, wie Herr Prås. Wilson durch seine unamerikanische Haltung, durch seinen Ehrgeiz, durch seinen Verrat an wahrer Humanităt, wahrer Neutralităt und striktem Volkerrecht, seine unverantwortliche Englanddienerei unter der Heuchlermaske der Humanităt und Gerechtigkeitsliebe ein befreundetes Land, das um seine Existenz kampft, zu demutigen und in den Krieg mit der Union zu treiben sucht. Es ist nicht ein kolassaler Starrsinn--wir möchten fast sagen Blödsinn--wenn der Prăs. unser Land in den Kriegen treiben will, weil er sich weigert, Amerikanern zu verbieten, auf armierten Dampfern kriegführender Mächte zu reisen? ${ }^{275}$

The Blatt again tried to rally the people to write to their representatives in Washington. "Scharfe Proteste notwendig" was a special feature. The United States was on the verge of a war with Germany because of a British-loving President Wilson. The interests of America demanded peace. Every patriot, especially every German-American, had to do all he could to help avoid the danger threatening America. It wasn't enough to gnash teeth and lift the fist in protest. The people had to make themselves heard. Washington was the center of the controversy. Hundreds and thousands of dispatches would have to be sent to Washington to let their representatives know how the people felt. It had to happen now. Two examples of telegrams both in English followed.

Readers were told to fill in the names of their Representatives and Senators:

Your constituents urge and expect you to stand like a rock against the passing frenzy of insane and criminal folly on the part of the small portion of interested persons who are clamoring for war. We want peace. Nothing warrants any other action.

If warlike rumors coming from Washington are true will you let me assure you that the great majority of your constituents stand for peace, believe war now unnecessary and uncalled for and will resent being precipitated into the European conflict. $^{276}$

It was the execution of a woman, one Miss Edith Cavell, by the Germans, however, that for a time took the spotlight off presidential politics and generated the most 
vehement denunciations of Germany by the American press in the years before America entered the war. Miss Cavell, an English nurse, was accused by Germany of assisting British prisoners to escape. She was subsequently tried and executed for her crimes. The British propaganda offices seized this issue and exploited it to the maximum. The outcry against Germany was tremendous in the United States and England. The idea of shooting a woman was extremely abhorrent to Americans and, although the British had also executed women even before Miss Cavell was shot, these facts were roundly ignored by the Allied Powers, and generally dismissed by the German propagandists as unimportant. ${ }^{277}$ This was one of the German propaganda apparatus's bigger mistakes.

The Blatt, however, counters what it calls "die Maßlose Hetzkampagne" against Germany created by "[d]ie Erschießung der Edith Cavell" by accusing England of an even more heinous crime; that of executing a woman who was one of its own citizens. The proof offered by the Blatt is documents confiscated in Antwerp by the German army.

The Blatt translates them into German:

"Uebersetzung"

Provinzialverwaltung v. Antwerpen

Antwerpen, 20. Aug. 1914.

Herr Bürgermeister!

Im Namen des General Befehlshabers der Provinz habe ich die Ehre, Sie zu ersuchen, so schnell als möglich den folgenden Auszug aus einem Urteil, welches durch den Kriegsrat der dritten Heeresabteilung gefallt würde, in Ihrer Gemeinde anheften zu lassen:

Der Kriegsrat der 3. Heeresabteilung in seiner Sitzung zu Lőwen vom 17. Aug. 1914 hat in Sachen 1) Troupin, Karl, Journalist, geboren zu Lüttich am 24. Feb. 1873 wohnhaft in Brüssel, Noorblan Nr. 8; 2) Romel, Friedrich Wilhelm, geboren zu Verviers am 12. Apr. 1887, Ingenieur-Elektriker, wohnhaft in Paris; 3) Van Wauterghem, Julia geboren zu Brüssel, am 26. Jan. 1872, Ehefrau des Eugen Hontang wohnhaft in Brüssel, Noorblan Nr. 8.

Ueberwiesen: Der erste des Verrats und der Spionage, die beiden anderen der Spionage die drei Beschuldigen zum Tode verurteilt. 
Das Urteil wurde vollstreckt zu Lowen am 18. desselben Monats.

Der Kriegsminister

Auf Befehl:

Der General Auditor

gez. Baron Durette

Für den Chef der allgemeinen Kriegsverwaltung

gez. de Longueville

Der Gouverneur

Baron von der Nerveen von Schide ${ }^{278}$

Certainly, comments Br. Cölestin, condemning a woman to death and carrying out such a sentence was a difficult concept in 1916 for either the Allies or the Central Powers, nevertheless, a woman, such as Edith Cavell or Julia Van Wauterghem, had stepped outside of the societally sanctioned frame of her sex and:

[begab] sich im so mehr des ihrem Geschlechte sonst zukommenden Anspruches auf besondere Schonung, als sie dasselbe bewußt und freventlich zum Verderben anderer mißbraucht....Man kann den Spruch des belgischen Kriegsgerichtes von Löwen gegen Julia Van Wauterghem nicht zu einem Akte der Barbarei stempeln, aber auch nicht den Spruch des deutschen Kriegsgerichtes von Brüssel gegen Edith Cavell. ${ }^{279}$

The Dutch Limberger Koerier remarks about the Edith Cavell case:

"Wenn die Belgier und Franzosen das Recht haben, Frauen (Spioninnen) zu
erschießen und wir glauben, daß niemand ihnen dieses Recht bestreiten kann--,
dann haben es auch die Deutschen. Wenn die Engländer den Deutschen dieses
Recht bestreiten, dann müssen sie es auch ihren Bundesgenossen verweigern: das
haben sie aber niemals getan. Uebrigens, solange die Engländer es nicht wagen,
die Namen der von ihnen im Tower zu Tode gebrachten Spione bekannt zu geben,
bleibt es eine offene Frage, ob sie nicht selbst ebenfalls Frauen erschossen
haben. Und deshalb ist in unseren Augen all der Lărm, den England über das
Erschießen einer Frau schlägt, nichts anderes als Mache, um in England
Erbitterung zu erwecken, damit man mehr Freiwillige erhalte. ${ }^{280}$

The Edith Cavell case was a short-lived sensation in the pages of American newspapers. Basically, the story had been exploited for its human interest angle by the British propaganda office but failed to gather any great momentum. Although considered 
important enough to be front page news in most English language newspapers, most German publications like the St. Josephs-Blatt buried the story deep in their pages. Instead, Br. Cölestin considered Pres. Wilson and his campaign for reelection a more important story than Miss Cavell and kept it prominently featured in the Rundschau.

Only a few months previous to the execution of Miss Cavell, Wilson had insulted German-Americans with his anti-hyphen speech. During one of his reelection stumps he tried to correct what the Blatt referred to as an injustice to millions of America's best citizens. In Milwaukie, the Athens of German-America, Wilson suddenly took on a completely new demeanor. In his previous speech, his "Jahresbotschaft," hyphenated Americans had been described in very harsh terms. In his latest speech he spoke in a very conciliatory manner. He knew that most members of the audience were GermanAmericans and his speech was not to Congress but to a block of voters. He denounced those who were saying that Americans would not stand together in an emergency and crisis.

America, explained Wilson, got her blood and energy from almost every nation in the world, and men could not forget their heritage. In the beginning of the war, he had believed that such a heterogeneous population could have spelled disaster. In the Athens speech, he admitted that he had been wrong. His speech peaked with the words: "Ich weiß, daß wenn es zur Probe kommen wird, jede hiesige Mannesherz zuerst für Amerika schlagen wird." Naturally he received enthusiastic applause from the predominantly German-American audience. ${ }^{281}$

Br. Collestin was not satisfied with the President's speech, however. Wilson had branded hyphenated Americans traitors before the whole country. The editor wanted the President to find the courage to correct the insult. German-Americans, insisted Br. Cőlestin, were not "Windfahnen" on which one day the President could throw dirt and 
the next day drive to the fields like sheep. Mr. Wilson had to make his word good by making sure America could trade with neutral countries and by making sure America's mail was left untouched. ${ }^{282}$

The Blatt was constantly aware of the possibility of becoming known as an antiWilson, and subsequently, an anti-American newspaper. In response to this, Br. Cölestin printed as many articles as he could on prominent Americans, especially politicians, who disagreed with President Wilson's policies. A special feature, conspicuously boxed-in at the top of page 3 of the May 5, 1916, issue, was titled "Kongreßabgeordneter Mann zur Rede Wilsons." The editor emphasized Congressman Mann's words by printing excerpts in English:

"It is a hypocritical speech, probably for campaign purposes."

"The Pres. has been pro-English all during this controversy."

"I said at the time of the McLemore Resolution that the Pres. wanted to get us into war with Germany, and I say the same thing now."

"Pres. Wilson is Scotch-Presbyterian and he hates the Dutsch [sic]."

Representative Mann, Illinois ${ }^{283}$

In another article four pages later the Blatt reports that Senator Bardaman of Missouri spoke to President Wilson on April 20th. The Senator reportedly told the President that he could not understand why one could immediately make Germany responsible for every break in rights, while allowing the Allies whatever they wanted. The senator insisted that the southern states had suffered under the disregard of neutral rights because the administration had refused to lift a finger in response. Bardaman told the President to be truly neutral and treat all belligerents the same. He was sure the American people did not want war with Germany or any other warring power in Europe.

282 Blatt 11 February 1916: 1.

283 Blatt 5 May 1916: 3. 
He ended his talk with Wilson by telling him that he prayed to God that Germany would find an honorable way to give in to Wilson's demands and thereby keep the peace. The article ended with the sentiment that although few could express it the way Senator Bardaman could, hundreds of thousands thought as he did. The American people did not want war with Germany. 284

By May of 1916 , the Blatt was ready to make an announcement regarding who, if anyone, the newspaper would endorse for President of the United States. It may have been obvious to any of the Blatt's readers that Wilson was not going to get the endorsement, yet $\mathrm{Br}$. Cölestin had not made any pronouncements. Although GermanAmericans had historically been strongly loyal to the Democratic ticket, the politicians and the political analysts could not confidently predict how the election would go. Many of those whom the analysts used to measure the popularity of politicians, were still undecided. Even many editors of German-American newspapers were vascillating; not wanting to endorse Wilson, but also not wanting to endorse a Republican.

That month, in response to a number of different incidents, hundreds of thousands of citizens, members of numerous German-American organizations, began a national drive to gather signatures on a petition to be sent to Congress. The petition drive, a last ditch effort to show the strength of the anti-war, pro-neutrality contingency of Americans, was highly successful. The American press, however, took those involved in the drive to task, accusing them of trying to minipulate the congress and influence their representatives in the cause of Germany. The German-American organizations involved were accused of being under the influence and control of Imperial Germany.

For Br. Cölestin and other German-American editors, Wilson sealed his fate when on May 3rd, it was reported that he agreed with those accusing the German-Americans of wrong-doing. The incident was important enough for the Blatt to title a report in 
English, "Sweet Land of Liberty?" Br. Colestin reminded his readers that, according to the Constitution, every American, regardless of ethnic heritage, had the right to petition his government. No one, including the President of the United States, a congressman, or a senator could legally deny an American citizen this right, yet Wilson, reported the Blatt, intended to take steps against such influence on members of Congress. $\mathrm{Br}$. Collestin felt that the President had miscalculated in this instance, since the Constitution had been written for him as well as the people. ${ }^{285}$

The Blatt, in a separate article, then endorses Mr. Albert B. Cummins, Republican from Iowa, for the presidency of the United States. In a special article titled "Wer ist Albert B. Cummins?" the candidate's background is given and qualifications listed. With a home in Iowa, his life was described as one of a typical American, raised and educated in western Pennsylvania. He had worked his way up as a carpenter, porter, land surveyor, railroad engineer, and lawyer, later becoming Governor of Iowa. In his second term in the Senate, he had made a name for himself by recognizing the important questions of the day. He is described as an able and powerful statesman, a great lawyer, a protector of the rights of the worker, and would, if elected serve the country with honor. ${ }^{286}$

Mr. Cummins lost his party's nomination for the presidency to Hughes, whom the Blatt did not endorse. On November 20,1916, the Blatt reports the outcome of the election:

Die Würfel sind gefallen. Endlich am Donerstag Abend wurde zur Gewißheit, daß Woodrow Wilson zum zweiten Male zum Prăsident den Ver. Staaten gewăhlt worden ist. Die Mehrheit über Hughes ist sehr klein. War das eine Spannung und Nachfrage seit Mittwoch Morgen!...Zum ersten Male in der Geschichte der Union...war es der Westen, welche den Ausschlag gegeben hat. Wir haben nichts zu bereuen; wir haben einen ehrlichen Kampf gekămpft; denn nicht der Partei, sondern der Person, dem Kandidaten galt unser Widerspruch....Wir wünschen Mr. Wilson für seinen zweiten Termin alles Gute: möge er sich aufraffen die Fehler seinen vier Jahre gut zu machen soweit das noch möglich ist; moge er sich von 
der besonderen Freundschaft für England losreißen und nach dem Muster G. Washington's die Freiheiten und Rechte unseres schonen, großen Landes hochhalten und möge er aufhơren, einen großen Prozentsatz der Bürger der Ver. Staaten anzurempeln, weil sie den Mut haben, gegenteiliger Meinung zu sein.... Wir Deutsch-Amerikaner dürfen uns freuen, wenn auch unser Kandidat nicht gewăhlt worden ist, denn wir haben durch unsere Stellungsnahme dem Lande mehr benützt, als irgend jemand. Wir Deutsch-Amerikaner und die uns befreundeten Irlănder, waren es, die sowohl die Demokraten als auch die Republikaner gezwungen haben, das Zusammengehen mit England, welches unserem Lande seit vielen Jahren gedroht hat und es an den Rand des Abrundes geführt haben würde, auf zugeben....287

On December 1, 1916, the Rundschau announces that on November 21, 1916, Kaiser Franz Joseph von Osterreich died. He was 18 years old when he ascended the throne and ruled almost 68 years. The new Emperor was Karl Franz Joseph, 29 years old. The empress was named $\mathrm{Zita}$. 


\section{CHAPTER VI}

THE FINAL YEARS: $1917-1919$

1917 was a year of personal sorrow for many Americans of German descent. When the United States finally declared war on Germany, not every German-American reacted with surprise; many, especially those reporting the news, had fully expected it; they had only been unsure of when it might happen. Despite this, German-Americans who had expected the inevitable, were saddened and troubled by the news.

Finding themselves face-to-face with problems that most other Americans never would encounter, German-Americans were forced to prove their loyalty to their adopted country daily. Out of a need for personal protection, many stopped speaking German; some anglicized their family names; other found themselves at the front fighting men who might be their relatives.

On February 9, 1917, the front page of the St. Josephs-Blatt reads "Die Schicksalsstunde der Nation hat geschlagen: die Regierung der Ver. Staaten had die diplomatischen Beziehungen zu Deutschland abgebrochen." The report continues:

Damit ist ein Ereignis eingetreten, welches seit fast zwei Jahren wie eine schwere Wolke über der Union geschwebt und die Beziehungen zwischen Deutschland und den Ver. Staaten mehr oder weniger getrübt hat. Der Bruch mit Deutschland meint noch nicht der Krieg; wir hoffen deshalb noch immer, daß unser Land nicht tătlich in den schrecklichen Krieg eingreifen wird. ${ }^{288}$

Even with all that had previously taken place, with all the bad news that was flooding the headlines around the country, Br. Colestin was hopeful that the Wilson administration would still be able to salvage relations with Germany. 
Yet as the month of February continued, the news became more and more dismal; it seemed that the threat of war increased with each passing hour. Indications from Washington increased the anxiety of German-Americans. Newapaper editors, like Br. Cölestin, saw "Kriegszensur" threaten the freedom of the German-American press. ${ }^{289}$ When Germany finally announced unequivocally the beginning of all-out submarine warfare, Br. Cölestin admitted that "die Würfel sind gefallen":

Sollte es aber, was Gott verhüten möge, doch noch dazu kommen, so wird die Liebe der Bürger deutscher Abkunft zum Lande ihrer Geburt, so heiß sie auch jetzt in seiner schwersten Prüfungsstunde in ihren Herzen glüht, nicht vermögen, sie in ihren freiwillig übernommenen, heiligen Pflichten gegen das

Adoptivvaterland schwankend zu machen. Und eingedenk dieser Pflichten muß und wird der Bürger deutscher Herkunft in diesen hochernsten kritischen Tagen sein amerikanische Bürgertum über die Anhănglichkeit und Liebe an das Land seiner Geburt stellen und danach handeln. ${ }^{290}$

The report continues with a dire warning and request from Br. Colestin to those Germans in the United States who were not yet American citizens:

Heißsporne, die mit unbedachten Aeußerungen und Urteilen um sich werfen, leisten damit ihrem eigenen Vaterlande keinen Dienst, und ihr so zum Ausdruck gebrachter vermeintlicher Patriotismus bewirkt nur vielleicht einen wirklichen Haß gegen Deutschland heraufzubeschwören, der jetzt, wir können dies wohl ohne Gefahr eines Widerspruchs sagen, in den breiten Massen des amerikanischen Volkes nicht existiert. ${ }^{291}$

Br. Cölestin ended his call for calm with an editorial directed to German-Americans. In it he tells his countrymen that silence is golden, especially now more than ever for German-Americans. ${ }^{292}$

In an unusual break with the traditional front page set-up, the Blatt reprinted a political cartoon at the beginning of the February 23, 1917, Rundschau. The cartoon depicts a crowd running after a coin labelled "the ammunition dollar." The crowd is 
yelling "we don't want peace, on with the war, to $H$... with the pacifists, don't disturb our business." The caption to the entire cartoon reads: "Sind wir solchen Mănnern auf Gnad und Ungnad ausgeliefert?" The Rundschau itself is no more optimistic in its report that even though war did not yet exist between the United States and the Axis Powers, it was sure to come. The article made it clear that too many "asses" existed in the United States, asses who were influential, who were thirsting for German blood. ${ }^{293}$ In the same issue, Br. Colestin departed from his usual anti-American press rhetoric and admitted that with a few exceptions, the American people and press had been fair to German-Americans and had not questioned their loyalty. ${ }^{294}$

Br. Colestin maintained, despite all criticism, that it would be a shame if the United States went to war with Germany because of her submarine policy, especially since Germany was following this policy out of self-defense against the illegal, inhumane policy of starvation that England was using against Germany. ${ }^{295}$ He continued to believe that the German blockade of England was not only illegal and causing untold hardship on women, children, the weak, and the ill, but that the blockade and its results were unpopular with the American public. ${ }^{296}$

Yet it was still unclear just where the American public actually did stand in the controversy. Stories in the Blatt and other newspapers in March of 1917 indicated that German-Americans were under constant threat of verbal abuse and at times, physical harassment. There were stories of instances when German-Americans were stopped on the street and detained until they swore allegiance to the United States. The Blatt's editorial answer to such harassment was to admonish its readers to answer that they had

293 Blatt 23 February 1917: 1.

294 Blatt 23 February 1917: 1.

295 Blatt 23 February 1917: 1.

296 Blatt 23 February 1917: 1. 
taken an oath once when becoming citizens and in good German tradition, that meant for life. ${ }^{297}$ Some Americans, especially German-Americans were signing loyalty oaths, either voluntarily or under duress. It had somehow become the fashion to do so in early 1917. Again, the Blatt rebukes those doing so and scoids that the signing of loyalty oaths was an insult to every true American, since the real American had always been loyal and always would. 298

On the front page of the April 13, 1917, edition of the St. Josephs-Blatt, with no headlines, no fuss, Br. Cölestin told his readers that a condition of war existed between Germany and the United States. The simplicity of the announcement was an eloquent indication of the sadness that Br. Cölestin and German-Americans throughout the United States must have felt when President Wilson went before the Congress of the United States on April 2nd and requested a declaration of war against Germany. The Rundschau in this issue was devoted to a reprint of President Wilson's entire speech.

Br. Cölestin's silence on the matter extended to the editorial page. He made no mention of the war, no reference to President Wilson's request. However, on page 5, in a special boxed-in feature, the Blatt gave its readers some indication of the consequences of a war with Germany. "Jetzt ruft die Pflicht; die Stimme des Herzens muß schweigen, wenn das Herz auch brechen will."

The report warned German-Americans that despite everything, they had to stay loyal to the United States. It was clear to the Blatt's editor that it didn't matter if German-Americans considered the war just or unjust or if they agreed with the action of the American government. They had sworn allegiance to their country-of-choice, and it was their duty to keep that oath. Br. Cölestin warned German-Americans and Germans in America to remain quiet, to guard themselves against strangers, to hold their criticism 
of the government. He admonished them not to speak of the war at all, and to be aware that even the walls in their own homes of ten had ears. Even the privacy of the mail was not considered safe from prying eyes. And sadly, even though it was the right of every American to criticize their government, Br. Collestin warned his readers that now it had to stop; for their own protection, silence and loyalty were their first duties as citizens. $^{299}$

Even with those dire predictions and warnings, Br. Colestin let his readers know that during those critical times, he would still not hesitate to report truthfully and without fear what was happening in the theater of war. He had not shied away from disputing lies about the Central Powers when they were being printed by the press; it had been a bitter fight, but, according to Br. Cölestin, $99 \%$ of the Blatt's readers had stood by him, and he requested that they now remain true to the Blatt. He felt that it was now especially important that the German-American still get the truth about the war and the Central Powers. He indicated that the Blatt was being censored at this time, because the government had won very wide powers with the declaration of war, or would soon get them. He warned that spies were everywhere, and that he would have to consider every word carefully, because the blandest utterance could be taken and be used against him and the Blatt. ${ }^{300}$

Taking all of the above comments into consideration, one might believe that $\mathrm{Br}$. Cölestin would have become reticent in his praise of Germany or the Central Powers. In the April 20, 1917, Rundschau, however, there is no mistaking the editor's continued love for and admiration of Germany. The report openly praises Germany as the best governed country in the world. In the same vein, the population is said to enjoy more freedom than the average American believed, and the German citizen, according to the story, was 
well protected against exploitation. In fact, the story goes on to say that both Americans and English had testified that no country in the world had taken care of its working class and its poor as well as Germany. And in the final line of this Rundschau Br. Colestin optimistically states that Germany could not be defeated or destroyed as long as it was united. ${ }^{301}$

In April of 1917 most of the few remaining news sources from Germany had been effectively silenced. The one remaining wireless station in Sayville, too, ahd been closed and what war information available to newspapers was completely controlled by either the British censor, or the American government news services. The Vom Völkerkrieg chronology of war events was curtailed drastically, because the Blatt was completely cut off from German news sources. Br. Colestin even suggested that the chronology might have to be discontinued because of the lack of information coming in..$^{302}$

To counter some of the anti-German hysteria that swept the country after the declaration of war, the Blatt continually published articles affirming the loyalty of German-American citizens. Br. Colestin disputed the validity of Allied claims of German atrocities, while publishing stories of how England had plundered the American economy during the early years of the war. ${ }^{303}$ It was this continuing belief in Germany and her innocence and the continuing positive coverage of Germany in the pages of the Blatt that, no doubt, precipitated the banning of the St. Josephs-Blatt in Canada, as announced in an editorial on May 18, 1917. According to Br. Collestin, Canada banned the Blatt because it had tried to teach its readers the truth. ${ }^{304}$

In an editorial on June 15,1917 , the Blatt quotes Rudyard Kipling extensively:

301 Blatt 20 April 1917: 1.

302 Blatt 20 April 1917: 5.

303 Blatt 27 April 1917: 3.

304 Blatt 18 May 1917: 4. 
Verrückt geworden oder von teuflichem Haße betreffen ist der englische Hofdicter Rudyard Kipling, der in dem in Bordeaux erscheinenden Blatte "La Petite Gironde" einen Artikel veroffentlicht hat, in welchem er sagt "Das franzősische Volk braucht sich über die von die von den Deutschen angerichteten Verwüstungen nicht zu grămen. Deutschland wird für alles büßen müßen, was es Frankreich angetan hat. Die Rache die Alliierten wird kaltblütig sein, so kaltblütig wie die Verbrechen des Feindes. Den Deutschen darf nie wieder gestattet werden, den Boden der alliierten Lander zu betreten. Alle Brücke zwischen ihnen und uns sind abgebrochen. Sie tun Böses, wo immer sie hinkommen, gleichviel ob sie Soldaten, Kaufleute oder Millionăre sind. Wie Vazillen vergiften sie überall ihre Umgebung. Es ist an der Zeit, ihnen klar zu machen, daß sie aus der menschlichen Gesellschaft ausgestoßen sind. In Zukunft wird es zwei Rassen auf der Erde geben: die menschliche und die deutsche. Danton hat seinezeit gesagt: "Die Nationen erklărten uns den Krieg und wir sandten ihnen den Kopf eines Konnigs", sagt der britische Schriftsteller. "Erst wenn uns die Deutschen den Kopf ihres Kaisers senden, werden wir imstande sein, zu beurteilen, ob sie die Freiheit wirklich wollen oder nicht." -- Man wird sich selbstverständlich mit einem so hirnverbrannten Kerl nicht herumschlage, aber es muß konstatiert werden, wie weit der Blinde $\mathrm{Haß}$ Menschen treiben kann. Es ist ein Zeitdokument. ${ }^{305}$

One particularly blatant piece of propaganda used by the Allies during 1917 was a story of the German "Leichenfett-Fabrik." According to the English press the Germans had a factory to extract fat from the corpses of dead enenmy fighters. Despite the obvious lack of credibility of any such idea, in 1917 some sections of the American public firmly believed the reports. Br. Cölestin simply dismissed the story as an "Ausgeburt" not worth disputing. However, he did find the sources of such a piece interesting. He cites both the Matin in Paris and the Daily Mail in London as the "heros" of the piece. Both of these newspapers had reproduced a picture from the Lokal-Anzeiger in Berlin as proof of the existence of the factory.

On June 29, 1917, the Blatt printed a story extolling the constancy of GermanAmerican loyalty to the United States. The article itself testifies to Br. Collestin's own constancy of loyalty to the German-American cause:

Wir Deutsch-Amerikaner haben niemals soviel Ursache gehabt, uns zu freuen, im Stillen ein Jubellied anzustimmen, als gegenwărtig. Das mag zu dieser Stunde fast komisch klingen und doch ist es Tatsache. In stiller Trauer gedenken wir zwar der bitteren Ereignisse der letzten Monate, aber im rechten Lichte 
betrachtet hat sie uns zu Helden gemacht, die den harten Sieg aber sich selbst errungen haben. Obschon das Herz brechen wollte, haben wir die höchste Bürgertugend, die unwandelbare, aufrichtige Treue gehalten und geubt gegen unsere selbsterwăhlte neue Heimat, Unter Millionen unserer Landsleute waren es nur ganz wenige, die sich verführen ließen und mit den Gesetzen des Landes in konflikt kamen. Das ist aber eine Ruhmestat wie kein zweiter Volksteil unseres Landes sie auf zuweisen imstande ist. Turm hoch stehen wir über unseren Verleumdern; wir stehen im Sonnenglanz des Hochgebirges, unsere Gegner im Nebel des Tales. Die kleinen und großen Koter mogen noch so laut uns anbellen, wir sind und bleiben was wir immer gewesen sind: treue Deutsch-Amerikaner; die feste Stütze unseres Landes und unserer Konstitution. Prăsident Wilson ist von dieser Tatsache überzeugt, denn er hat wiederholt darauf hingewiesen, daß die Deutsch-Amerikaner mit sehr wenigen Ausnahmen sich immer als gute Bürger zeigten, und ausdrūcklich erklărte er: an der Loyalităt der Deutsch-Amerikaner dürfe nicht gezweifelt werden.... ${ }^{306}$

Br. Cölestin recognizes President Wilson's and the American government's fair treatment of German-Americans in a time when the rhetoric was getting increasingly hostile. The government's campaign to register all male German citizens residing in the United States had been carried off without undue sharpness or trouble. The government had even gone so far as to warn American citizens against anti-German actions. Even the press, according to $\mathrm{Br}$. Collestin, had treated the German element in the United States justly and without undue malice, with a few exceptions:

Wir haben immer im Vordergrunde des Treffens gestanden und es hat nicht an Tadel gefehlt, das St. Josephs-Blatt sei zu scharf and sollte sich in dieser ernsten Zeit măßigen. Wir bereuen keine Zeile, die wir geschrieben haben, denn wir sind nicht nur so gut amerikanisch wie nur irgend ein englisches Blatt, sondern besser als so manches. "America first"; England zuletzt"; das ist unser Losung. Die Deutsch-amerikaner aber, wenn man gerecht sein will, darauf zurückzuführen sein, daß ein sehr großes Teil der angloamerikanischen Presse von allem Anfang an, ja noch ehe der europaische Krieg wirklich begonnen hatte, im schärfster Weise loszog gegen alles, was Deutsch war oder als Deutsch galt; gegen die Deutschamerikaner noch mehr als gegen die Deutschen. Die starke anti-britische Stimmung unter den Deutschamerikanern und in der deutschschreibenden Presse des Landes wurde hervorgerufen and genăhrt durch die ganz und gar britische Haltung des gröBten Teils der in der Landessprache schreibenden Presse und deren alsbald offensichtliches heißes Streben, die Ver. Staaten auf Seiten Englands in den Krieg hineinzutreiben. Druck erzeugt Gegendruck. Es ist im Laufe der letzten paar Jahre in deutschamerikanischen Zeitungen so manches geschrieben worden, was besser ungeschrieben geblieben wăre, es fiel manches unbedachte Wort. Es wurde in deutschschreibenden Zeitungen scharfe, of vielleicht ungerechte Kritik geübt an de Politik der 
Administration und des Landes; das war aber nicht amerikafeindlich, nicht eingegeben von feindlicher Gesinnung gegen Amerika, sondern vielmehr von der Sorge um den Frieden und die Unabhăngigkeit der Republik. Der Verdacht, die Befürchtung, Amerika solle ganz und gar "verbritischt", praktisch zu einem Teil des britischen Weltreichs gemacht und um seine Unabhăngigkeit gebracht werden, führte die Feder, wenn in jenen schweren Tagen in der deutschamerikanischen Presse gegen England und die proenglische, zum Kriege treibende Strömmung, gegen die Administration und ihre Politik losgedonnert wurde. Die deutschschreibenden Zeitungen des Landes sind gut und nur amerikanisch bis auf die Knochen, und ihre Redakteure schreiben, ob sie Burger oder Reichsdeutsche sind, so gut sie's verstehen, im Interesse ihrer Leser, und das heißt "Amerikaner". Denn ihre Leser sind in der erdruckenden mehrzahl Amerikaner, für die nur sein kann, was für Amerika gut ist. Es mag auch da einzige Ausnahmen geben, aber auch für diese Ausnahmen ist nicht Mangel an guten Willen, sondern nur Mangel an rechtem Verstehen und Können verantwortlich. Es steht der probritische Presse schlecht an, die deutschamerikanische Presse und das deutsche Element der Bürgerschaft zu verdăchtigen. Als sich's darum handelte, die Einheit des Landes zu erhalten, da stand die deutschamerikanische Presse einmütig auf die Seiten der Union, stellte das deutsche Element einen ganz unverhăltnismăßig großen Prozentsatz der Kămpfer, wăhrend von probritischer und britischer Seite gegen die Union gewühlt und gewirkt wurde. Wenn heute das deutsche Element des Landes keine helle Kriegsbegeisterung zeigt, so ist der Grund nicht antiamerikanische Gesinnung, oder Untreue den Ver. Staaten gegenüber. Im Gegenteil. Der Hauptgrund ist der Verdacht, daß sich's mehr um einen Krieg zur Rettung, Erhaltung und Mehrung des britischen Weltreichs und seiner Macht handelt, als um einen Krieg im Interesse der Freiheit und Amerikas. Und daß dieser Verdacht angesichts der Erklärungen des Prăsidenten noch bestehen kann, das ist eben den Herzblättern zu danken, die Mißtrauen und $\mathrm{Haß}$ săen, wo gegenseitiges Vertrauen und Freundschaft so nötig sind. ${ }^{307}$

This article in the Rundschau is in fact, an apology for the actions of the St.

Josephs-Blatt, and of all German-American newspapers. It also marks the beginning of Br. Collestin's defense of the Blatt. Up to this point, he had at times defended editorials and articles that he had published. He had even gone so far as to defend his loyalty to Germany and the German cause in the United States. Now, however, we see an editor who is defending the very existence of his newspaper, its right to publish the truth, and its right to continue to do so. Part of the defense of the Blatt is a defense of GermanAmerican newspapers in general. It is also a defense of all things German. German was 
more than a nationality; it was a culture, a collection of traditions, a way of life, epitomized by the language.

Throughout the history of the Blatt Br. Colestin had defended the use of German in the United States. He had praised it as a world langauge. When the war began, he found himself defending it even more, but when the United States finally entered the war on the side of the Allies, German-Americans like Br. Colestin found themselves apologizing for their culture by defending their language.

"Die deutsche Sprache hat nichts verbrochen," begins a special feature on July 13, 1917. The article decried the "Hetze" against American newspapers appearing in the German language. Br. Collestin denied the allegations of disloyalty leveled against the German-American press. He lamented the idea prevalent in 1917 that it was criminal to use any language other than the "Landesprache" and considered the movement to stop all German language instruction in schools in the United States as deplorable. He cites the Christian Science Monitor in his story. According to an undated article, newspapers in many areas of the United States had reported a continuing agitation in the public schools, mostly by the parents of students, to discontinue the teaching of German, but according to the article, the Monitor stated that the German language was not to blame. 308

Br. Cölestin praised the ethnic press in the same edition in an editorial titled "Ein Lob für die fremdsprachige Presse." He believed that in those perilous times, when there were citizens wanting to forbid the German press, the German language press had become a necessity, serving two important functions: teaching the German-Americans about political life, and strengthening their trust in the American government. ${ }^{309}$ 
The plight of the ethnic press in the United States, especially German-American publications, grew much worse in 1917 and 1918. A campaign of censorship grew stronger as American involvement in the war deepened. On March 22, 1918, a small but significant notice in English appeared for the first time on page 1 of the St. JosephsBlatt: True translation filed with the Post Master at Saint Benedict, Oregon, March 15, 1918, as required by the Act of October $5,1917 .^{310}$

In conjunction with the Espionage bill, Act of June 15, 1917, the Act of October 6, 1917, (the Trading with the Enemy Act) required all foreign language publications printing any information, stories, or editorials in which reference was made to the American government or the conduct of the war, to file a true translation of such articles with the nearest post office. By overseeing the news being sent through the mail system, the Post Office, according to interpretations of the law in 1917, was declining "to become an agent in the circulation of printed matter which it regards as injurious to the people. ${ }^{\text {311 }}$

Copies of all ethnic publications were sent to Washintong D.C. and other locations to be read by a force of paid and volunteer translators, readers, and assistants. If found to be "unmailable" under the Espionage Act, the paper was denied the use of the secondclass mailing privilege. In the most extreme cases, a newspaper "might be denied the use of the mails altogether. In that case no mail would be delivered to the address of the offending publication." ${ }^{n 12}$

Foreign-language newspapers could apply for a permit allowing them to forego the filing of the translation with the Post Office. Of those applying between October 1917

310 Blatt 22 March 1918: 1.

311 See John L. Thomas, Lotteries, Frauds and Obscenity in the Mails (columbia, Miss.: n.p., 1900) 243.

312 Robert E. Park, The Immigrant Press and its Control (New York: Harper \& Brothers, 1922) 440. 
and January 1919 , only 650 newspapers were issued such a permit. ${ }^{313}$ The St. Josephs-

Blatt was not one of them.

Perhaps this is not surprising since the Blatt's editorial policy was still openly

pro-German. The Blatt even in March of 1918 was reveling in German victories:

Die zahlreichen Luftkămpfe und Ueberfălle, sowie der Vorstoß der Deutschen nach Odessa sind die hervorragendsten Ereignisse der Woche auf den

Kriegsschauplătzen...

Die Deutschen haben Odessa, der wichtigste russische Hafen am Schwarzen Meer besetzt. Welche Bewandtnis es mit diesem Vorstoß hat, lăßt sich nicht sagen. Die Vermutung liegt nahe, daß die Zentral măchte das ungeheuer reiche Hinterland und die noch in Odessa gelagerten Schătze an Getreide und Fracht überhaupt zu sichern versuchen. ${ }^{314}$

Br. Colestin used the Rundschau to continue his defense of the German-American

press and the St. Josephs-Blatt:

Brüllend umwölkt mich der Dampf der "Geschützel". Je lănger, je schlimmer, kritischer und rătselhafter wird nicht nur die allgemeine Welt- und Kriegslage, sondern auch die Psychologie der Menschen und Volker; man wird angerempelt, wenn man auch sein Bestes tut, nicht nur seine Bürgerpflichten treu zu erfüllen, sondern auch die Bestrebungen der Regierung zu unterstützen. Zum Xmal haben wir in stammenden Worten zur Loyalităt ermahnt, aufgefordert sich den Kriegsmaßnahmen der Bundesregierung zu fügen und sie nach bestem Vermögen zu fördern und zu unterstützen: wir haben mitgeholfen die beiden Kriegsanleihen unter Dach zu bringen und den verschiedenen Liebeswerken, wie das Rote Kreuz, Sammlung für die Columbus Ritter, Armenier, etc. das Wort geredet und haben niemals wissentlich weder die Regierung noch ihre Maßnahmen kritisiert, noch viel weniger ihr Verlegenheiten bereitet. Und doch werden wir angegriffen, weil wir eine deutsche, katholische Zeitung herausgeben, weil wir ein Mönch sind. Wir haben ein gerechtes Urteil in keiner Weise zu fürchten: wir sind überzeugt, daß gerade in dieser kritischen Zeit loyale Zeitungen, wie das St. Josephs-Blatt, dem Lande die grőßten Dienste leisten kőnnen und daß wir ganz im Sinne der Bundesregierung und des Prăsidenten handeln, wenn wir einenseits die gegen loyale Deutschamerikaner ausgestreute Saat des Hasses bekămpfen, da dadurch unsere Bürger nicht geeint, sondern entzweit werden, anderseits aber zu freudiger Loyalităt und unentwegter Unterstützung der Regierung affordern. Eine Zeitung ist noch lange nicht unloyal, weil sie in deutscher Sprache erscheint. Erst ganz kürzlich fand die Bundesregierung sich veranläßt, durch das Komitee des offentlichen Nachrichtenbureau dem verbrechenschen Treiben gewisser Leute entgegenzutreten, dessen einzige Aufgabe es zu sein scheint, Zwietracht zu săen. Amerika braucht in dieser schweren Zeit den letzten Mann und den letzten 
Dollar. an uns soll es nicht fehlen, wir sind und bleiben loyal, aber wir mũssen uns jede bossartige Verdăchtigung verbitten. ${ }^{315}$

On the same page as the Rundschau in the lower right hand corner, in English appeared the following announcement:

The Third Liberty Loan.

The campaign for the third Liberty Loan will be opened on the 6th of April, the anniversary of the declaration of a state of war between the United States and Germany....

Secretary McAdoo chose the 6th of April as the day to open the campaign as the most fitting date to call for a patriotic response to the summons to duty to every American, to ask from the people at home the same fervent patriotism that actuates our gallant sons on the battlefields of France and on the waters of the Atlantic. ${ }^{316}$

The Blatt, following the example of most other German-American newspapers, involved itself in promoting the Liberty Loan drives as part of its own campaign to prove its loyalty to the United States.

On March 29, 1918, for the first time since war had been declared in Europe, the Blatt's fron page began with headlines, and in English: "IN JUSTICE TO OURSELVES." Scattered throughout the front page are five boxed areas, some in English, some in German. The first, in English read:

"The Christmas Membership Drive" the American Red Cross.

Publishers, Benedictine Press, Mount Angel, Oregon.

Dear Sir:

We thank you for your telegram and are pleased to advise that we are mailing you today the cuts you request. Would appreciate it if you will send the writer a copy of your paper when published.

Thanking you for your cooperation, I remain,

Yours very truly,

315 Blatt 22 March 1918: 1.

316 Blatt 22 March 1918: 1. 


\section{A.C. Black}

Publicity Manager

Christmas Membership Drive $\mathbf{3 1 7}^{\mathbf{3}}$

The opening paragraph of the Rundschau explains that for the first time in 20 or more years the front page of the St. Josephs-Blatt will be used solely in defence of itself. The writer, explains Br. Colestin, whether out of misunderstanding or other unknown causes, is considered "pro-Deutsch." He tells the readers that there are people who were attempting to get the Blatt surpressed. However, he insists, "Wir sind uns keiner Schuld bewußt."

Br. Cölestin then publishes one of the strongest defenses of the Blatı and its positions to date. The article, printed in both German and English, is significant to the history of the Blatt and is reprinted here in its entirety:

Vielleicht zum ersten Male seit zwanzig oder mehr Jahren müssen wir diese Woche die erste Seite des St. Josephs-Blatt, auf welcher wir gewöhnlich in unparteiischer Weise Umschau zu halten pflegten über die wichtigsten Vorgănge der Welt, der Verteidigung des Blattes einrăumen. Ob auf Mißverstăndnissen oder auf uns unbekannten Ursachen beruhend, Tatsache ist, daß man den Schriftsteller für pro-Deutsch hålt, ein Redner von Stadt zu Stadt zieht, das St. Josephs-Blatt denunzierend, ja es soll sogar Leute geben, welche bestrebt sind, auf die Regierung einen Druck auszuüben, das St. Josephs-Blatt zu unterdrücken. Wir sind uns keiner Schuld bewußt. Wir kőnnen uns die Vorwürfe nur dadurch erklăren, daß man Aeußerungen falsch auslegt, eine andere als beabsichtigte Deutung gibt oder vielleicht gar religiőse Motive dabei mitspielen. Sofort nach Erklärung des Kriegeszustandes zwischen Deutschland und den Ver. Staaten, haben wir in der Ausgabe vom 13. April, 1917 an unsere Leser folgende Mahnung gerichtet: Jetzt ruft die Pflicht die Stimme des Herzens muß erster Linie gilt jetzt für die Deutschamerikaner, daß sie unbedingt loyal sein müssen. Ob wir diesen Krieg für berechtigt halten, ob wir das Verhalten der Regierung billigen oder verurteilen, darauf kommt es jetzt nicht an. Wir haben dem Lande unserer Wahl Treue geschworen, und wir sind es unseren Stammesgenossen, unseren Mitbürgern und uns selbst schuldig, da $B$ wir unseren Eid treu und unverbrüchlich halten: das ist unsere Pflicht. Das war unsere Prinzipienerklărung nach dem Kriegsausbruch: wir haben sie hochgehalten und haben sie immer und immer wiederholt. Als loyaler Amerikaner sind wir noch weiter gegangen: wir haben die Maßnahmen der Regierung unterstützt, ihrem Wünsche entsprechend ihre Hauptbestrebungen durch Veröffentlichung einschlägiger Artikel gefördert, soweit es der beschrănkte Raum gestattete. Nur Eines haben wir unterlassen: wir haben nicht eingestimmt in den Haßgesang, der unsere große Presse erfüllte, weil in einer christlichen Gesellschaftsordnung der Haß keine Rolle spielen darf, wie 
denn auch die Bundesregierung sich gegen diese Bewegung erklărt hat. Sicherlich kann man auch heute noch loyal sein, ohne das christliche Sittengesetz zu verletzest. [sic] Nur wenn das nicht mehr moglich ist, dann werden wir die Konsequenzen ziehen. Es ist ganz gegen die ausgesprochenen Willen der Bundesregierung, loyale Amerikaner zu schmăhen und zu verleumden, weil sie aus Deutschland kommen oder einen deutschen Namen haben. Sowohl Prăsident Wilson als auch Generalanwalt Gregory, haben offentlich der Treue und Hingebung amerikanischer Bürger deutscher Abkunft höchstes Lob gespendet. Ihre Söhne sind ruhig dem Rufe des Prăsidenten gefolgt; aus deutschen Familien ziehen die Sőhne hinaus in dem Kampf; Vater und Mutter erteilen ihnen in den Mutterlauten den Abschiedssegen, damit sie ausharren und dem neuen Vaterlande zum Siege verhelfen, wie es ihr Văter in den beiden großen Kriegen unseres Landes getan haben, deren Verdienste um unser Land die Geschichte mit dem Griff im Granit gemeißelt hat. Wenn wieder normale Zeiten zurückkehrt sein werden, wird man diese freudig anerkennen.

Wenn es unter den Millionen Adoptivbürgern eine kleine Anzahl gibt, welche den Verrăter spielen, so wird das nicht uberraschen, denn wir finden solche unter allen Nationen, aber die loyalen Amerikaner deutscher Abkunft haben nichts mit ihnen gemein; sie verabscheuen und verurteilen sie. Wie bitter denn muß es sie krănken, daß sie trotzdem verdăchtigt und geschmăht werden! Gerade aus diesem Grunde haben heute Zeitungen in deutscher Sprache eine bedeutungsvolle Mission zum Besten unseres Vaterlandes zu erfüllen. Ihre Aufgabe ist es jetzt besonders, das Feuer der Liebe in den Herzen der Amerikaner deutscher Abkunft zum neuen Vaterlande aufrecht zu erhalten, sie zur Hingebung und Förderung der Regierungsmaßnahmen zu begeistern. Das wird auch in Regierungskreisen anerkannt.

Die persőnlichen Angriffe lassen uns kalt, aber die Angriffe auf das St. Josephs-Blatt müssen wir zurückweisen. Deshalb die obige Erklärung. Wir sind kein Deutsch-Amerikaner, unsere Wiege stand in der Schweiz, über welche Jahrhunderte das Banner der Demokratie wehte, ehe die Vereinigten Staaten sich von England unabhăngig machten. Wir sind geborener Demokrat und gerade aus diesem Grunde hăngen wir mit unbegrenzter Liebe und felsenfester Treue am freien Amerika. Deshalb werden wir der eingangs erwăhnten Prinzipienerklärung auch fernerhin treu bleiben. Wir unterhalten keinen Verkehr mit irgend einer feindlichen Macht; unsere Quellen sind die englischen Tageszeitungen und einzelne schweizerische Blätter, die uns aber nur ausnahmsweise erreichen. Ist vielleicht einmal ein Wort gefallen, welches anstoßen mochte oder zu einer falschen Auslegung geeignet war, so ist das nicht mit Absicht geschehen und das wăre auch keinen Grund uns zu verdăchtigen und als pro-deutsch anzuklagen, denn nicht nach einzelnen Worten oder Sätzen, sondern nach dem Betragen, nach den Taten beurteilt man den Mann. ${ }^{318}$

The English translation followed on the same page:

For the first time perhaps within twenty years or more we must give over the first page of the St. Josephs-Blatt -- usually devoted to a review of the world's most important events -- to the defense of the paper. Whether on account of misunderstandings or due to causes unbeknown to us, the facts are: that the editor is held to be pro-German; that a speaker is traveling from city to city, 
denouncing the St. Josephs-Blatt; nay it is even said that there are persons, who are trying to bring pressure to bear upon the government to suppress the St. Josephs-Blatt. We can explain such accusations only by the fact that our utterances are misinterpreted, a construction different from the one intended is applied, or else religious motives are, perhaps involved. Immediately after the declaration of war we admonished our readers in the issue of April 13, 1917, as follows: "Now duty calls, the voice of the heart must be silent though the heartstrings should break. German-Americans must be loyal under all circumstances. Whether or not we hold this war to be justified, whether or not we sanction the attitude of the government, cannot now come into consideration. We have sworn allegiance to the land of our choice, and we owe it as a duty to our descendants, to our fellow citizens, and to ourselves, to keep the oath faithfully and inviolably."

Such was the declaration of our principles after the outbreak of the war. We have clung to these principles and have repeated them again and again. As loyal Americans we went even further: We have supported the Government --in accord with its wishes-- in its main endeavors by publishing articles relating thereto as far as our limited space permitted. Only one thing we have omitted: We did not join in the song of hate filling our metropolitan press to-day, since in a truly Christian organization, hate finds no place. The government also has declared itself against such agitation. Surely it ought to be possible to be loyal to-day without breaking the principles of Christian morals. Should this not be possible, we must take the consequences.

It is against the expressed wish of the federal government to revile and calumniate loyal Americans because they carry a German name. President Wilson as well as Attorney General Gregory have publicly and highly commended the loyalty and devotion of Americans of German descent. Their sons have quietly followed the call of the President; sons of German families have gone forth to battle; fathers and mothers have bestowed their blessings upon them in their mother tongue at parting, to spur them on to hold out to the end, and to do their utmost to gain victory for the country of their adoption, as did their forefathers whose services history has carved in granite, in the two great wars of our country.

That there are among millions of adopted citizens a small number who play traitor cannot be surprising. We find them among all nations; but loyal citizens of German descent have nothing in common with them and detest and censure them. How grieved then they must feel to be held in suspicion and reviled! It is for this reason that papers in the German langauge have to fulfill a significant mission to-day for the good of our country. Their duty it is particularly, to enkindle the fire of love towards their adopted country in the hearts of the German-Americans, and to fill them with devotion and good will towards the furtherance of government measures. This fact is recognized even in government circles.

The personal attacks distrub us little: but the attacks on the St. Josephs-Blatt we must refute. Wherefore the above explanation. We are not GermanAmerican. The land of our birth is Switzerland, over which floated the banner of democracy several centuries before the United States secured her independence from England. We were born democratic and because of this fact we are attached to free America with boundless love, and loyalty as firm as a rock.

We will therefore continue to be true to the above mentioned principles. We do not maintain intercourse with any enemy nation; our sources of information 
are the English daily journals and a few Swiss papers which reach us occasionally. If ever a word has been dropped which might offend or be liable to misinterpretation, it is unintentional, and it cannot be a sufficient reason to accuse us of being pro-German, for it is by his conduct that a man must be judged and not by single words and phrases, whose obvious meaning and intent may be distorted by the casual reader.

Bro. Celestine, O.S.B.

Editor, St. Josephs-Blatt ${ }^{319}$

The Blatt follows the rest of the German-American press in 1918 and begins to print more English articles and advertisements. As part of its campaign to seem more American and loyal to the American cause the Blatt also follows the lead of other German-American newspapers and begins to print the image of the American flag on the front page of every edition. Also part of this loyalty campaign is an article in the April 5, 1918, Rundschau on the "dritte Freiheitsanleihe" sale. It became increasingly important for any German-American newspaper to indicate its loyalty to the American cause at every turn. Many, and the St. Josephs-Blatt was no exception, took great pains in taking part in, if not taking the lead in the advertising of the bond sales:

Als guter Amerikaner und Patriot empfehlen wir sie und heben die Erwartung, daß sie überzeichnet wird nur zwar vornehmlich mit Hilfe der Amerikaner deutscher Abkunft. ${ }^{320}$

Br. Corlestin reminded his readers that even though he did not think the GermanAmerican had to wear his patriotism on his sleeve, it was, in this case, important that he do just that. The German-American was facing daily insults calling his patriotism into question. The editor of the Blalt warned that in order not to add ammunition to the weapons of their enemies, the American of German descent had to fight with every weapon at hand:

Wir haben viele Feinde hierzulande. Wir haben auch Freunde. Diese machen uns, den Amerikanern deutschen Stammes den Vorwurf, daß wir durch unsere würdenvolle ruhige Zurückhaltung unsere Feinde, die auch ihre Feinde sind, 
stărken, und sie (unsere Freunde) außer Stande setzen, für uns einzutreten, wie sie möchten und wie sich's gehörte....das darf nicht sein. Wer Amerikanischer Bürger ist, muB sich als Amerikaner zeigen. Das ist der Punkt. Wir sind alle Amerikaner, gleichviel welche Sprache wir zu Hause oder mit Vorliebe sprechen. Die Sprachenfreiheit, das Recht die Muttersprache zu benutzen wird durch das dringliche Verlangen der Administration, daß auch in deutscher Sprache Propaganda gemacht werden für die Freiheitsanleihe betont und sicher bestellt. Propaganda für die dritte Freiheitsanleihe in deutscher Sprache ist Propaganda für die deutsche Sprache selbst. ${ }^{321}$

On April 12, 1918, after 30 years of continual publication, Br. Colestin published the 15 th edition of the St. Josephs-Blatt for 1918. It was the last edition to be published until September 10, 1919, one year and eight months later. Br. Cölestin had found that the best thing for both the paper and his community was to suspend publication until better times. It was not made clear exactly why he chose this moment; even the front page explanation was circumspect in explaining his actions:

Vorliegende Nummer ist die letzte Ausgabe des St. Josephs-Blattes bis zum Eintritt normaler Zeiten. Obwohl loyal Land und Regierung gegenüber, zur Bürgertreue und Unterstützung der Regierungsmaßnahmen auffordernd, müssen wir doch der Gewalt weichen. Es bleibt uns keine andere Wahl. Wie schwer uns das wird, die wir seit dreißig Jahren das Blatt in die weite Welt hinausgesandt haben, vermogen wir heute nicht auszudrücken, denn nur wer drei Jahrzehnte mit zehntausenden lieber Freunde und Bekannten sozusagen Freude und Leid geteilt hat; kann begreifen, was es meint, wenn dieses Freundschaf tsband so plötzlich entzwei gerissen wird. Es existierte keine Zeitung in der Union, dessen Leserkreis in einem so familiăren Verhăltnisse zu den Herausgebern gestanden haben, wie es beim St. Josephs-Blatt der Fall war.

Dafür, für all die unzăhligen Beweise der Liebe und Freundschaft mőchten wir bei diesem traurigen Anlasse ganz besonder danken. Der heilige Joseph, dem wir im Laufe der Jahre viele neue Verehrer zugeführt haben, mőge es allen tausendfach lohnen. Möge dieser unser großer Patron aber auch für uns bitten, damit wir bald wieder in der Lage sind, sein Blatt neuerdings herauszugeben. Sobald sich uns eine Möglichkeit bietet, wird das St. Josephs-Blatt wieder erscheinen, was hoffentlich bald der Fall sein wird....

Die Redaktion braucht sich vor dem Leserkreis in keiner Weise zu verteidigen; alle Leser wissen, daß wir "Gott zur Ehr', dem Bösen zur Wehr -- der Wahrheit zum Schutz, der Lüge zum Trutz" gekămpft haben. Ein besseres und schoneres Programm gibt es nicht für eine katholische Zeitung, aber diese Ideale sind heute nicht mehr zeitgemăß. Nun scheiden wir. Möge der Allgütige durch die Fürbitte des heiligen Joseph ein baldiges Wiedersehen geben! Behüt Euch Gott!

Die Redaktion. ${ }^{\mathbf{3 2 2}}$ 
The last issue of the St. Josephs-Blatt was business as usual. Br. Colestin printed differing versions of battles that had taken place; the British version: north of the Somm all British positions held, no noteworthy battles were reported; then the German version: south of the Somm the Germans have forced the British out of their old placements and broken through the important British positions. If he had only one version of the battle to report, he noted that the British or the German report was missing. Even in the end, he insisted on getting the German version to the public. The editorials in the April 12, 1918, issue did not address the suspension of publication.

On September 10, 1919, Br. Cölestin began the 31st year of the St.Josephs-Blatt. The war was over, but the law still required that a true translation of the paper be filed with the postmaster. The news in the Rundschau concentrated on the revolution in Germany. The editorial on page 4 gave some explanation as to why the Blatt had been suspended:

In eigener Sache. Weder eine Entschuldigung noch eine Kursănderung ist notwendig für uns. Wie in der Vergangenheit, so wird auch in Zukunft Unterhaltung, Erbauung und Belehrung unsere Ausgabe sein, wăhrend wir jede Gelegenheit benützen werden, in den Herzen unserer Leser die Liebe, Treue und Anhănglichkeit an die selbstgewăhlte neue Heimat zu wecken und zu befestigen. $^{323}$

Another editorial followed:

Auf der achten Seite des Blattes finden die Leser einige Bemerkungen über den Grund der [unreadable] des Blattes.

Das Scheiden war uns damals nicht leicht, aber es mußte sein. Seit beinahe dreißig Jahren sind wir an der Spitze des Blattes gestanden; alle Zeit an exponiertem Posten, die meisten Jahre waren Kampf jahre, aber trotzdem haben wir den Beruf geliebt trotz aller Bürden, seiner Dornen und Bitterkeiten. Das Hohe, das in ihm liegt, die Fülle von Gelegenheiten, Gutes in demselben zu wirken, haben über alles andere stets hinweggeholfen.

Etwas erleichterte das Scheiden von euch, liebe Freunde. Kriegszorn und Kriegslüge hatten die Menschenherzen vergiftet, die Grenzen der freien Meinungsăußerung wurden immer enger gezogen und die Schuld der Welt hăuste sich derart, daß man an der Zukunft der Menschheit fast verzweifeln mußte, zumal wenn die besten Absichten verdreht oder gar als Verbrechen ausgelegt und 
treue Loyalităt verdăchtigt wurden, weil wir nicht eingestimmt in den wústen Haßgesang, da in einer christlichen Gesellschaft der Haß keine Rolle spielen darf.

Nun ist der holde Friede wieder gekehrt, wenn auch in ganz anderer Weise, als die Menschheit sich trăumte. Wir gehen wieder normalen Zeiten entgegen, die Bahn ist frei. Darum kehrt St. Joseph wieder, um als lieber Gast bei euch einzukehren. Der Weltkrieg hat manches in Trümmer geschlagen, mit dem man sich ein Vierteljahrhundert geistig und seelisch verwachsen fühlte. Eine neue Welt ist im Werden. Aus einem Chaos, in noch nicht greifbaren Umrissen und wallenden Nebeln steigt sie auf. Wir stehen ihr nicht ohne Glauben an sie gegenuber, noch weniger als Gleichgültiger, obwohl dem Leiter eines Blattes enge Grenzen gezogen sind. Nein, die neu werdende Erscheinungen, die sie gebăren wird, werden uns auf dem Posten finden, wie der wachthabende Offizier, der in sturmgepeitschter Nacht das Schiff sicher zum Ziele führt.

Darum neuerdings: Vorwărts mit Gott! Durch Nacht zum Licht, durch Kampf zur Sieg. Ihr aber, liebe Freunde, müßt uns treu bleiben und daselbe rege Interesse am Blatt nehmen, wie früher, denn ohne eure Hilfe wăre unser Unternehmen ein Fehlschlag. Unsere Aufgabe und unsere Arbeit sind dann noch schwer genug, wenn ihr auch die Pflicht tut. Also vorwărts mit Gottes Hilfe unter dem Schutzes des heiligen Joseph! ${ }^{321}$

On page 8, under the service cross of Mt. Angel College was a special article

printed in English:

The St. Josephs-Blatt, our Catholic German weekly, voluntarily suspended publication on April 12, 1918, for reasons which we now make known to our subscribers. We wish it to be understood that neither the Post Office Department nor any State or Federal Office interfered with or forced us to discontinue the publication of the St. Josephs-Blatt.

The chief characteristic of our paper has been and is the defense of Catholic Faith and instruction in Catholic [unreadable]....Cliques whose patriotism was absorbed by their fanaticism, whose one business it was to blow tin-horns questioned our patriotism because the St. Josephs-Blatt was printed in the German language.

We could not expose ourselves to the threats of those cliques nor could we afford to have our institutions' loyalty to the stars and stripes questioned. It was a time when anti-Catholics spoke much and did as they are now doing, little thinking. On this account we chose to suspend the publication of the St. Josephs-Blatt, whereas in truth and by the laws of our country we could well have continued its weekly issue.

The St. Josephs-Blatt supported the government and sought to enkindle in its readers a generous love for this country; and urged and encouraged GermanAmericans to be heart and hand with our country's cause. No honest man or body of men questioned our fidelity to the United States. On the contrary, our Service Flag speaks louder than words, and the part we took in the Liberty Loans, Red Cross Drives, etc., has been highly commended by the Treasury Department, Mrs. McAdoo, organizations of Oregon, etc.

We shall continue to teach patriotism [unreadable]....that makes every sacrifice for the country's honor. We shall endeavor to instill love of our God's most 
favored country that ever more it may be the pride of the nations, "the land of the free" and "the home of the brave" -- the home of the oppressed and downtrodden of other lands. ${ }^{325}$ 


\section{CHAPTER VII}

\section{CONCLUSIONS}

The St. Josephs-Blatt continued under the editorialship of Br. Colestin until his death on June 20,1929 . The Blatt's circulation never reached the levels it had achieved in its heyday, but nevertheless remained high enough to warrant its continued publication by the Benedictines at Mt. Angel until 1952. By any criteria the Blatt was a success.

The St. Josephs-Blatt is a valuable historical source for information on the ideas and thoughts of the German-American during the years 1896 through 1919. This thesis showed that Br. Cölestin, as the editor of the Blatt, was a barometer of the feelings, ideals, fears, and joys of this disparate ethnic group. What Br. Cölestin wrote about was what concerned his readers. His defiance of the nativists of the 1800's and 1900's benefited all immigrants coming to Oregon and the Northwest. The fight for his church and faith was part of an ongoing battle for religious freedom, ramifications of which are felt to this day. His defense of civil liberties and personal freedoms was a defense of a free man's right in a neutral country to choose to support the unpopular cause. In a time when being German was highly unpopular his unflinching belief that the GermanAmerican's heritage, traditions, customs, and language constituted an intregal part of America's cultural synthesis was a victory for all ethnic groups becoming part of the great melting pot.

For these reasons the St. Josephs-Blatt should be read by historians, sociologists, anthropologists, and linguists interested in the Northwest's valuable contribution to America's ethnic and religious story. This thesis endeavors to give the reader a small 
sampling of the greater body of information waiting for discovery. This thesis is also

the story of one man, and his ideas. To quote Br. Colestin's obituary:

Er war unbestreitbar ein großer Geist. Wir sind gezwungen dies zu sagen, trotzdem es uns widerstrebt, unsere Kulturarbeit zu loben, aber gerade zu einer Zeit, da die religiősen Fanatiker neue Schlăge gegen deutsche Kultur ausführen, ist einer der ersten Vertreter deutschchristlicher Kultur von seinem Arbeitsfelde abberufen worden. Es fallt nun seinen Nachfolgern anheim, deutsch katholisches Wesen, deutsche Sprache und Schrift soweit es ihren Krăften möglich ist zu erhalten suchen.

Hab' Dank für Deine stete Treu' im Kleinen, Den festen Mut, wenn es das Große galt!

Wie wußtest weise $\mathrm{Du}$ ihn zu vereinen

Mit Rat -- ja, auch mit Tat -- für Jung und Alt!

Im Namen aller, die's erkannt und wissen,

Was Du für unser liebes Blatt getan,

Wie schmerzlich Deine Gegenwart vermissen --

Nimm diesen letzten Gruß beim Scheiden an!

Sieh' -- hinter mir -- da steht die Schar der Treuen,

Für die Du gütig schafftest Platz und Raum,

Durch Dich und durch Dein kluges Vorausschauen

Ward Wirklichkeit ihr lang gehegter Traum.

Dann kommen alle, die die "Rundschau" lesen,

Für die warst ein echter Volksprophet,

Dann jene, die Dein immer gleiches Wesen

Im Werk bewundern durften früh und spät.

Du schafftest, wirktest freundlich mit den andern,

Nicht über ihnen, wie's des Obern Recht;

Ein ruhig freundliches zum Ziele Wandern --

Auch der Geringste fühlt' sich nicht als Knecht.

Nun zogst Du fort! -- Nichts kann Dich mehr versehren --

Gott nimmt Dich auf in Gnaden und in Ehren'

Denk' unser dort im Licht der Ewigkeit!

R.I.P. ${ }^{326}$ 


\section{BIBLIOGRAPHY}

Abrams, Ray H. Preachers Present Arms: A Study of Wartime Attitudes and Activities of the Churches and the Clergy in the United States, 1914-1918. Philadelphia: n.p., 1933.

Arndt, Karl J. and May E. Olson. Deutsch-Amerikanische Zeitungen und Zeitschriften: 1732-1955. Geschichte und Bibliographie. Heidelberg: Quelle \& Meyer, 1961.

Barry, Colman James. The Catholic Church and German-Americans. Milwaukee: Bruce, 1953.

Beals, Carleton. Brass-Knuckle Crusade. The Great Know-Nothing Conspiracy: 18201860. New York: Hastings House, 1960.

Billington, Ray Allen. The Protestant Crusade, 1800-1860. A Study of the Origins of American Nativism. New York: Rinehart \& Company, Inc., 1952.

"Catholic Contributions to Oregon History." A reprint from St. Josephs Magazine. St. Benedict, OR.: Mt. Angel Abbey, Inc., 1959.

Child, Clifton James. The German-Americans in Politics, 1914-1917. Madison: n.p., 1939.

Clark, Victor S. "The German Press and the War." Historical Outlook, 8 (Nov., 1919): 425-28.

Cogley, John. Catholic America. New York: The Dial Press, 1973.

Cummins, Cedric C. Indiana Public Opinion and The World War: 1914-1917. Indianapolis: Indiana Historical Bureau, 1945.

Decker, Winfried C. Oregon und sein Deutschtum. New York: n.p., 1920.

Dolan, Jay P. The Immigrant Church: New York's Irish and German Catholics, 18151865. Baltimore: The Johns Hopkins University Press, 1975.

Faust, Albert Bernhardt. The German Element in the United States. New York: Arno Press, 1969.

Fell, Sister Marie Leonore. The Foundations of Nativism in American Textbooks, 17831860. Washington, D.C.: The Catholic University of America Press, 1941.

Hawgood, John Arkas. The Tragedy of German-America. New York: Arno Press and The New York Times, 1970.

Gleason, Philip, ed. Catholicism in America. Interpretations of American History. New York: Harper \& Row, 1970. 
Higham, John. Send These to Me. Immigrants in Urban America. Baltimore and London: The Johns Hopkins University Press, 1984.

--. Strangers in the Land: Patterns of American Nativism, 1860-1925. New Brunswick, New Jersey: Rutgers University Press, 1955.

Hill, Howard C. "The Americanization Movement." American Journal of Sociology, XXIV (1919): 609-42.

Hodes, Ursula. Mt. Angel. Oregon, 1848-1912. Thesis, (M.S.), University of Oregon, 1932.

Horrocks, Thomas. "The Know-Nothings. Politicking for Nativism." American History Illustrated, 17.9 (Jan., 1983): 22-9.

Hough, Emerson. Mass Violence in America. New York: Arno Press and The New York Times, 1969.

Hunter, Edward. In Many Voices: Our Fabulous Foreign-Language Press. Norman Park, GA: Norman College, n.d.

Irwin, Will. Propaganda and the News, or What makes you think so? Westport, CT: Greenwood Press, 1970.

Kahler, Erich. The Germans. Princeton, NJ: Princeton University Press, 1974.

Kallen, Horace M. Culture and Democracy in the United States: Studies in the Group Psychology of the American Peoples. New York: n.p., 1924.

Keller, Phyllis. States of Belonging: German-American Intellectuals and the First World War. Cambridge: Harvard University Press, 1979.

Kessler, Lauren. The Dissident Press: Alternative Journalism in American History. The Sage CommText Series 13. Beverly Hills: Sage Publications, 1984.

Laidlaw, John Raleigh. The Catholic Church in Oregon and the Work of its Archbishops. Smithtown, NY: Exposition Press, 1977.

Lasswell, Harold D. Propaganda Technique in the World War. London: Kegan Paul, Trench, Trubner \& Co., Ltd., 1927.

Link, Arthur S. Woodrow Wilson. Revolution, War, and Peace. Arlington Heights, IL: AHM Publishing Corporation, 1979.

Linkh, Richard M. American Catholicism and European Immigrants (1900-1924). New York: Center for Migration Studies, 1975.

Luebke, Frederick C. Bonds of Loyalty: German-Americans and World War I. Dekalb: Northern Illinois Univ. Press, 1974.

MacColl, Eugene Kimbark. The Growth of a City: Power and Politics in Portland, Oregon, 1915-1950. Portland: Georgian Press, 1979. 
Marty, Martin E., John G. Deedy, Jr., David Wolf Silverman, Robert Lekachman. The Religious Press in America. New York: Holt, Rinehart and Winston, 1963.

McCrank, Lawrence J. Mt. Angel Abbey: A Centennial History of the Benedictine Community and its Library. 1882-1982. Wilmington, DE: Scholarly Resources Inc., 1983.

Meynen, Emil. Bibliography on German Settlements in Colonial North America. 16831933. Leipzig: n.p., 1937.

Miller, Daniel. "Early German-American Newspapers." Pennsylvania German Society Proceedings and Addresses. 19 (1908): 107-10.

O'Grady, Joseph P., ed. The Immigrants' Influence on Wilson's Peace Policies. N.p.: University of Kentucky Press, 1967.

Park, Robert E. The Immigrant Press and its Control. New York: Harper \& Brothers, 1922.

Pochmann, Henry A., Arthur R. Schultz. Bibliography of German Culture in America to 1940. N.p., University of Wisconsin Press, 1954.

Rahill, Peter J. The Catholic in America. From Colonial Times to the Present Day. Chicago: Franciscan Herald Press, 1961.

Rippley, La Vern J. The German-Americans. Lanham, New York, London: University Press of America, 1984.

Robinson, Thomas Ryland. The German-Americans in Portland, Oregon, 1858-1887. Thesis (B.A.), Reed College, 1973.

Roetter, Charles. The Art of Psychological Warfare 1914-1945. New York: Stein \& Day, 1974.

Schmalenberger, Roberta Lee. The German-Oregonians. 1850-1918. Thesis, (B.A.), Portland State University, 1983.

Simon, Rita J. Public Opinion and the Immigrant: Print Media Coverage, 1880-1980. Lexington, MA: Lexington Books, 1985.

Tolzmann, Don Heinrich. German-Americana: a bibliography. Methchen, NJ: Scarebrow Press, 1975.

U.S. Attorney. Portland, OR. Letterpress Correspondence. 1896-1926. 69 vols. Oregon Historical Society, Portland, OR.

Van Allen, Rodger. The Commonweal and American Catholicism: The Magazine, the Movement, the Meaning. Philadelphia: Fortress Press, 1974.

Wittke, Carl Frederick. German-Americans and the World War, with Special Emphasis on Ohio's German-language Press. Columbus: n.p., 1936. 
---. The Germans in America: a Students Guide to Localized History. New York: Teachers College Press, 1967.

---. "Ohio's German-Language Press and the war." Ohio Archaelogical and Historical Quarterly. 28 (1919): 82-95. 